\title{
RADON RELEASE AND DISPERSION FROM AN OPEN PIT URANIUM MINE
}

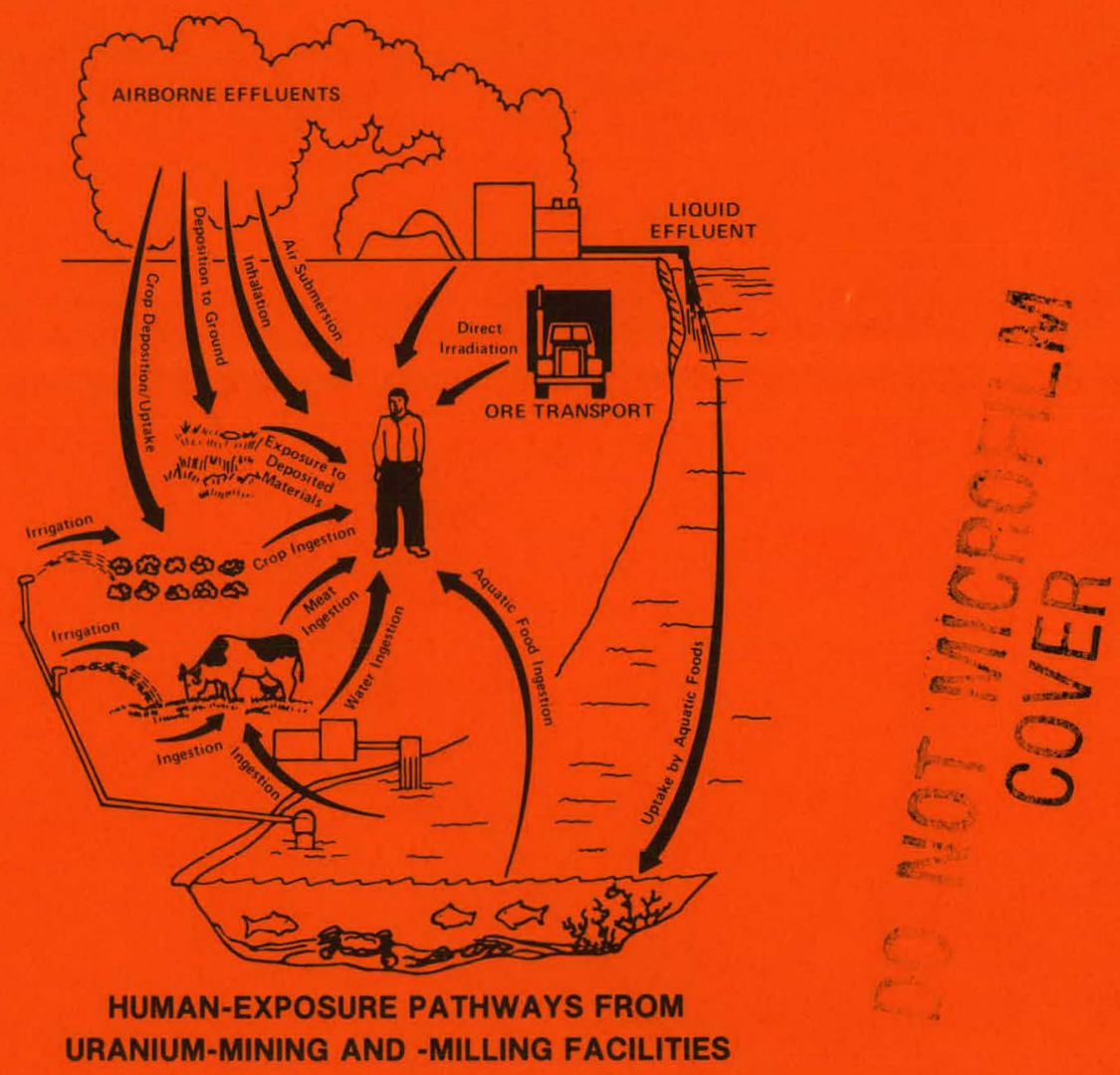

ARGQNNE NATIONAL KABORATQRY

ARGONNE NATIONAL LABORATORY, ARGONNE, ILLINOIS Prepared for the U. S. NUCLEAR REGULATORY COMMISSION under Interagency Agreement DOE 40-550-75 


\section{DISCLAIMER}

This report was prepared as an account of work sponsored by an agency of the United States Government. Neither the United States Government nor any agency Thereof, nor any of their employees, makes any warranty, express or implied, or assumes any legal liability or responsibility for the accuracy, completeness, or usefulness of any information, apparatus, product, or process disclosed, or represents that its use would not infringe privately owned rights. Reference herein to any specific commercial product, process, or service by trade name, trademark, manufacturer, or otherwise does not necessarily constitute or imply its endorsement, recommendation, or favoring by the United States Government or any agency thereof. The views and opinions of authors expressed herein do not necessarily state or reflect those of the United States Government or any agency thereof. 


\section{DISCLAIMER}

Portions of this document may be illegible in electronic image products. Images are produced from the best available original document. 
The facilities of Argonne National Laboratory are owned by the United States Government. Under the terms of a contract (W-31-109-Eng-38) among the U.S. Department of Energy, Argonne Universities Association and The University of Chicago, the University employs the staff and operates the Laboratory in accordance with policies and programs formulated, approved and reviewed by the Association.

\section{MEMBERS OF ARGONNE UNIVERSITIES ASSOCIATION}

The University of Arizona Carnegie-Mellon University Case Western Reserve University The University of Chicago University of Cincinnati Illinois Institute of Technology University of Illinois Indiana University The University of Iowa Iowa State University
The University of Kansas

Kansas State University

Loyola University of Chicago

Marquette University

The University of Michigan

Michigan State University

University of Minnesota

University of Missouri

Northwestern University

University of Notre Dame
The Ohio State University

Ohio University

The Pennsylvania State University

Purdue University

Saint Louis University

Southern Illinois University

The University of Texas at Austin

Washington University

Wayne State University

The University of Wisconsin-Madison

\section{NOTICE}

This report was prepared as an account of work sponsored by an agency of the United States Government. Neither the United States Government nor any agency thereof, or any of their employees, makes any warranty, expressed or implied, or assumes any legal liability or responsibility for any third party's use, or the results of such use, of any information, apparatus, product or process disclosed in this report, or represents that its use by such third party would not infringe privately owned rights.

Available from

GPO Sales Program

Division of Technical Information and Document Control

U. S. Nuclear Regulatory Commission

Washington, D.C. 20555

and

National Technical Information Service

Springfield, Virginia 22161 
DISCLAIMER

This book was prepared as an account of work sponsored by an agencey of the United States Government. Warranty. express or implied, or assor any agency thereof, nor any of their employees, makes any represents of usefulness of eny intormation, apparatus, product.

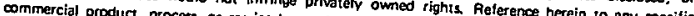
not necessarily constiture or inply oy trede name. tractemark, manufacturer, or o un speciltc

ARGONNE NATIONAL LABORATORY

9700 South Cass Avenue

Argonne, Illinois 60439

RADON RELEASE AND DISPERSION FROM AN

OPEN PIT URANIUM MINE

Walter E. Kisieleski

Program Manager

\section{Contributors}

James E. Carson

Clifford E. Dungey

Walter E. Kisieleski

Norbert D. Kretz
Jeffrey B. Lindstrom

Michael H. Momeni

Donald R. Rayno

Carmén S. Sabau

Division of Environmental Impact. Studies

June 1980

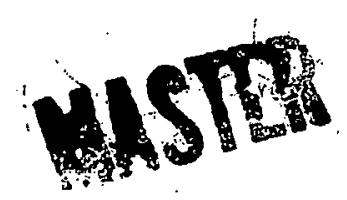

Prepared for

DISTAIBUTI

Office of Nuclear Regulatory Research

U.S. Nuclear Regulatory Commission

Washington, DC 20555

Under Interagency Agreement DOE 40-550-75

NRC FIN No. A2209 


\section{ABSTRACT}

Radon-222 flux from representative sections of the United Nuclear St. Anthony open-pit mine complex was measured. A flux measurement system incorporating a collection surface of $0.23 \mathrm{~m}^{2}$ with a desiccant to remove moisture was designed for this study. The collected radon was adsorbed on activated charcoal and the radon activity was measured by gamma spectroscopy (609 keV Bi-214). System design, calibration, and the procedure to determine radon flux density $\left(\mathrm{pCi} / \mathrm{m}^{2} \cdot \mathrm{s}\right)$ are described. A continuous series of radon flux densities were measured over a 5-month period at a control point in the mine. The average flux density at the control point was $1.9 \mathrm{pCi} / \mathrm{m}^{2} \cdot \mathrm{s}$ ( $\mathrm{range}$ : 0.44 to $\left.10.6 \mathrm{pCi} / \mathrm{m}^{2} \cdot \mathrm{s}\right)$. A close correlation between radon flux density variations and changes in barometric pressure was observed by a comparison of meteorological data and average daily radon flux density measured at the control point. The data from the control point was used to normalize measurements at other locations for variations in radon release rates caused by changing meteorological and climatic conditions. The release rate from each section of the mine was calculated from the average radon flux density and the area of the section, as determined from enlarged aerial photographs. The average radon flux density for eight locations over the ore-bearing section was $7.3 \mathrm{pCi} / \mathrm{m}^{2} \cdot \mathrm{s}$ (range: 0.41 to $36.0 \mathrm{pCi} / \mathrm{m}^{2} \cdot \mathrm{s}$ ). The average flux density for four locations over undisturbed topsoil was $0.17 \mathrm{pCi} / \mathrm{m}^{2} \cdot \mathrm{s}$ (range: 0.12 to $0.22 \mathrm{pCi} / \mathrm{m}^{2} \cdot \mathrm{s}$ ). The average $\mathrm{Ra}-226$ content of ten samples taken from the ore-bearing region was $102 \mathrm{pCi} / \mathrm{g}$ ore. The ratio of radon flux density to radium content (specific flux) was 0.072 [(pCi Rn-222/m² $\cdot \mathrm{s}) /(\mathrm{pCi} \mathrm{Ra}-226 / \mathrm{g}$ ore)]. This specific flux density is about five times lower than indicated by our previous measurements over aged tailings. The release rate from the entire $\mathrm{St}$. Anthony open pit was determined to be $3.5 \times 10^{\mathrm{b}} \mathrm{pCi} / \mathrm{s}$. This rate is comparable to the natural release of radon from one square mile of undisturbed topsoil.

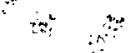

NRC

FIN 非

Title

A2209

Radon Release and Dispersion from an Open Pit Uranium Mine 


\section{FOREWORD}

One of the main concerns regarding the environment in the vicinity of uranium mining and milling operations has been the elevated atmospheric concentrations of radon-222 and its daughters. Uranium mining is a source of radon-222 which emanates from the high concentrations of radium-226 in the ore. The environmental assessment of the radon hazard is complicated by the variability of meteorological conditions which affect radon release and transport.

This report presents the results of the following tasks undertaken in this study:

(a) Measurement of radon flux from the ground.

(b) Measurement of working level and airborne radon concentrations.

(c) Measurement of meteorological parameters.

(d) Development of a theoretical model to describe the release of radon from open pit mines.

In January 1979, permission was obtained from United Nuclear Corporation to install equipment for these measurements at the St. Anthony Mine in the Grants, New Mexico, mineral belt. This report describes measurements and details of the studies performed from March through September 1979.

The authors express their appreclation to personnel of Unfted Nuclear Corporation--John Abbiss, Marshall Fletcher, Noel Savignac, John Cesar, William Sabo, and Frank Wills--for their cooperation and assistance. Acknowledgments are also extended to the following persons at Argonne National Laboratory: Sylvanus Tyler and Nancy Krysko for statistical data analysis; and William Hallett, Luis Saguinsin and Lalitha Sanathanan for their critical reviews of this report before publication.

The overall study was conducted by the Division of Environmental Impact Studies of Argonne National Laboratory. This activity was monitored by Harry Landon, John LeRohl, Bill Thompson; and currently by Laura Santos, all of the U.S. Nuclear Regulatory Commission. 


\section{DISCLAIMER}

This report was prepared as an account of work sponsored by an agency of the United States Government. Neither the United States Government nor any agency thereof, nor any of their employees, makes any warranty, express or implied, or assumes any legal liability or responsibility for the accuracy, completeness, or usefulness of any information, apparatus, product, or process disclosed, or represents that its use would not infringe privately owned rights. Reference herein to any specific commercial product, process, or service by trade name, trademark, manufacturer, or otherwise does not necessarily constitute or imply its endorsement, recommendation, or favoring by the United States Government or any agency thereof. The views and opinions of authors expressed herein do not necessarily state or reflect those of the United States Government or any agency thereof. 


\section{CONTENTS}

$\underline{\text { Page }}$

ABSTRACT . . . . . . . . . . . . . . . . . . . . . . . $1 i$

FOREWORD . . . . . . . . . . . . . . . . . . . . . . . . 1 . . . . .

LIST OF FIGURES . . . . . . . . . . . . . . . . . . . . . . . vi vi

LIST OF TABLES . . . . . . . . . . . . . . . . . . . . . . . . vii

EXECUTIVE SUMMARY . . . . . . . . . . . . . . . . . . . . . . . 1

INTRODUCTION . . . . . . . . . . . . . . . . . . . . . 3

METEOROLOGY (C.E. Dungey and J.E. Carson) . . . . . . . . . . . . . 8

SELECTION, TESTING, AND CALIBRATION OF THE RADON FLUX

MEASUREMENT SYSTEM (N.D. Kretz) . . . . . . . . . . . . . . . . 11

Radon Test Source for Canister Exposure .. . . . . . . . . . . . . 14

Gamma-Ray Intensity Measurement . . . . . . . . . . . . . . . . . 14

Charcoal Filter Adsorption Efficiency . . . . . . . . . . . . . 16

Radon Distribution in the Charcoal Filter . . . . . . . . . . . . 16

Canister Clearance and Reuse . . . . . . . . . . . . . . . . . 18

Collection and Measurement of Radon Flux . . . . . . . . . . . . . 21.

Lower Limit of Detection . . . . . . . . . . . . . . . . 23

FIELD MEASUREMENT OF RADON FLUX (N.D. Kretz and J.B. Lindstrom) . . . . 25

Normalization of Radon Flux Field Measurements . . . . . . . . . . 25

Surface Area Estimates at the -St. Anthony Mine . . . . . . . . . . . . 27

Radon Release from the Inactive Mine................. 27

Projection of Radon Release as a Function of Mine Age . . . . . . . . 32

Increase in Surface Area as a Function of Mine Development . . . . . 32

Projection of Radon Release Rates . . . . . . . . . . . . . . . 33

COMPARISON OF RADON FLUX WITH RADIUM-226 CONTENT OF ORE

(D.R. Rayno and C.S. Sabau) . . . . . . . . . . . . . . . . . . 36

RADON AIR CONCENTRATION AND WORKING LEVEL (M.H. Momeni and

J.B. Lindstrom) . . . . . . . . . . . . . . . . . . . . . . . . . . . . 39

Radon Concentration in Aịr . . . . . . . . . . . . . . . 40

Working Level Concentration . . . . . . . . . . . . . . . . 42

COMPARISON OF RADON GROUND FLUX WITH RADON AIR CONCENTRATION

(M.H. Momeni and N.D. Kretz) . . . . . . . . . . . . . . . . . . . . . 43

REFERENCES . . . . . . . . . . . . . . . . . . . . 4 49

APPENDIX A. SUMMARY OF METEOROLOGICAL DATA MEASURED ON A 10-METER

AND A 30-METER TOWER AT ST. ANTHONY MINE . . . . . . . . . 51

APPENDIX B. ESTIMATES OF RADON RELEASE RATES FROM RIPPING, REMOVAL,

AND CRUSHING OF ORE . . . . . . . . . . . . . . . . 


\section{FIGURES}

Figure

Page

1 Aerial Photograph of the St. Anthony Mine Region . . . . . . .

2 View of the St. Anthony Erosion Plane . . . . . . . . . . . . . . Geological Cross Section of the Morrison Formation Aerial Photograph Showing St. Anthony Mine Topography and Monitoring Stations.... . . . . . . . . . . . . 6 View of Active Open Pit . . . . . . . . . . . . . . . . . . 7 View of Overburden and Secondary Waste Deposits . . . . . . . 7 Installation of the 30-m Meteorological Tower. . . . . . . . . 9 Meteorological Equipment at Station SA-3 . . . . . . . . . . . 10 Smoke Showing Upward Air Motion . . . . . . . . . . . . . . . . 11 Sequential Pictures of Smoke and Dust from Blasting . . . . . . 12 Schematic of Radon Bubbler Assembly . . . . . . . . . . . . 15 Gamma-ray Counting Chamber with Charcoal Canister . . . . . . . 15 Plot of Radon Distribution in the Charcoal Filter . . . . . . . . 17 Exponential Decay of Radon-222 in the Canister . . . . . . . . . 18 Schematic of Canister Flushing System . . . . . . . . . . . 20 Radon Clearance as a Function of Time . . . . . . . . . . . . . 20 Schematic of Radon Collector . . . . . . . . . . . . . . . 22 Canister Counting System . . . . . . . . . . . . . . . . 24 Comparison of Radon Flux with Barometric Pressure at the Inactive Pit, 1 March to 12 July 1979 . . . . '. . . . . . . . 26 Comparison of Radon Flux at Reference and Background Locations . . . . . . . . . . . . . . . . . . . . 26 Enlarged Aerial View of the Inactive Pit Showing the Different Levels . . . . . . . . . . . . . . . . . . . 28 Schematic Vertical Cross Section of the Inactive Pit . . . . . 29 Projection of Ore Zone Surface Areas . . . . . . . . . . . . . 34 Projection of Radon Released from the Ore Zone . . . . . . . . . 35 Continuous Radon and Working-Level Monitor . . . . . . . . . . . 40 Air Concentrations of Radon at Station SA-1 on 13 June and 16 June and at Stations SA-1 and SA-4 on 30 June 1979 . . . . . . Comparison of Working Level and Radon Air Concentration at Station SA-1 on 14 June 1979 . . . . . . . . . . . . . . . . . . Schematic of Continuous Radon Flux Monitor . . . . . . . . . . 44 Concurrent Radon Air Concentration and Ground Flux at the Anaconda Uranium Mill . . . . . . . . . . . . . . . . . 46 Concurrent Radon Air Concentration and Ground Flux at the St. Anthony Mine 


\section{TABLES}

$\underline{\text { Table }}$

Page

I Estimated Surface Areas of Inactive Open Pit Mine Areas . . . . . 29

2 . Radon Flux Measured at Levels in the Inactive Open P1t . . . . . . 30

3 Radon Release Rate by Level . . . . . . . . . . . . . . . . . . . . 31

4 Ore Zone Flux in Order of Magnitude . . . . . . . . . . . . . . . . 31

5 Parameters Used to Convert Ore Production Rate to Volume . . . . . 33

6 Projected Annual Radon Release . . . . . . . . . . . . 35

7 Radon Flux from Ripped Ore in the Active Open Pit . . . . . . . . 36

8 Radium-226 Assay of Ore from the Active Mine . . . . . . . . . . 38

9 Comparison of Radon Flux wtih Radium-226 Concentration of Ore . . 38

10 Summary of Working Level and Radon Concentration Data at

11 Radon Air Concentration and Flux Measurement at st. Anthony Mine Station SA-1, April 1979 ............. 48 


\section{RADON RELEASE AND DISPERSION FROM AN OPEN PIT URANIUM MINE}

\section{EXECUTIVE SUMMARY}

Data from meteorological measurements made at the St. Anthony Mine, compared with data from the Albuquerque airport, "demonstrated that onsite information is needed to estimate local radon dispersion. Wind speed, wind direction, temperature, and dew polnt were measured at two locations at the mine. Variation in hourly wind direction indicated the effects of local terrain. Average wind speed was sometimes a factor of three lower than that at the airport. Differences in temperature and dew point were less significant.

A system using activated charcoal to collect radon was designed and tested at Argonne National Laboratory. A combination of the high radon adsorption efficiency and improved collection and counting techniques resulted in an overall reproducibility of: $\pm 3 \%$, with a lower detection limit for a 21-hour radon flux collection perlod of $0.025 \pm 0.013 \mathrm{pCi} / \mathrm{m}^{2} \cdot \mathrm{s}$. System design, calibration, and the procedure to determine radon flux density are described.

Radon-222 flux was measured from representative sections of the United Nuclear St. Anthony Mine open pit complex. A flux measurement system incorporating a collection surface of $0.23 \mathrm{~m}^{2}$ with a desiccant to remove moisture was designed for this study. The collected $\dot{r}$ adon was adsorbed on activated charcoal and the radon activity was measured by gamma spectroscopy (609 keV $B i-2(4)$. A continuous series of radon flux densities were measured over a 5 -month period at a control point in the mine. The average flux density at the control point was $1.9 \mathrm{pCi} / \mathrm{m}^{2} \cdot \mathrm{s}$ (range: 0.44 to $10.6 \mathrm{pCi} / \mathrm{m}^{2} \cdot \mathrm{s}$ ). A close correlation between radon flux density variations and changes in barometric pressure was observed by a comparison of meteorological data and average daily radon fiux density measured at the control point. The data from the 
control point were used to normalize measurements at other locations for variations in radon release rates caused by changing meteorological and climatic conditions. The release rate from each section of the mine was calculated from the average radon flux density and the area of the section, as determined from enlarged aerial photographs.: The average radon flux density for eight locations over the ore-bearing section was $7.3 \mathrm{pCi} / \mathrm{m}^{2} \cdot \mathrm{s}$ (range: 0.4 ! to $36.0 \mathrm{pCi} / \mathrm{m}^{2} \cdot \mathrm{s}$ ). The average fiux density for four locations over undisturbed topsoil was $0.17 \mathrm{pCi} / \mathrm{m}^{2} \cdot \mathrm{s}$ (range: 0.12 to $0.22 \mathrm{pCi} / \mathrm{m}^{2} \cdot \mathrm{s}$ ). The total release rate from the inactive open pit was determined to be $3.5 \times 10^{5} \mathrm{pCi} / \mathrm{s}$. These data, with surface area projections, were used to estimate annual radon release as a function of mine age.

The average Ra-226. content of ten samples. taken from the ore-bearing region, determined by the radon de-emanation method, was $102 \mathrm{pCi} / \mathrm{g}$. This average, divided by the average flux density for an undisturbed, ore-bearing region $\left(7.3 \mathrm{pCi} / \mathrm{m}^{2} \cdot \mathrm{s}\right)$, yielded a, specific flux of 0.072 . ( $\left.\mathrm{pCi} \cdot \mathrm{Rn}-222 / \mathrm{m}^{2} \cdot \mathrm{s}\right) /$ (pCi Ra-226/g ore).

Radon air concentration and working level measurements were made at locations in the St. Anthony Mine complex and at one background station $11 \mathrm{~km}$ north of the mine using a system containing a scintillation cell for continuous radon measurement and a surface barrier detector for measurement of working level. A comparison of the background and mine data taken at SA-I showed no observable differences in the air concentration of radon. A comparison of the working level averages showed an elevated working level at. the mine site.

Radon flux and air concentration were measured simultaneously using a continuous radon measurement syștem. This system--containing two scintillation cells, one for monitoring air concentration and the other for ground flux--is described. These data indicated a parallel rise and fall of ground exhalation and radon air concentration over a 24-hour period. The air concentration varied by a factor of four, ground flux by a factor of two. 


\section{INTRODUCTION}

One of the hazards associated with uranium mining arises from inhalation of radon and its daughters. The ore, overburden, and inclusive wastes removed during mining contain radionuclides in the U-238 series. The Ra-226 in these materials decays to $\mathrm{Rn}-222$, which is released to the atmosphere.

Surface mining for uranium ore is a dynamic process involving continual stripping of overburden to expose and then remove the underlying ore deposits. The procedure for surface mining ore, often synonymously called strip mining or open pit mining, is a combination of area mining and contour mining. Area mining is mostly applicable to gently rolling hills, whereas contour mining is often practiced in mountainous or steep, hilly regions. In area mining, a trench or box cut is made through the overburden to expose the ore; the overburden, inclusive waste, and marginal ore removed from the pit are deposited in piles on the ground surface near the mine. In contour mining, the overburden is removed from the strata above the ore bed and is discharged down the hill. Often, contour mining is combined with auger mining (horizontal tunnels) following the ore seams.

Mining procedures such as backfilling reduce the area of the exposed ore zone and thus reduce the total radon released. Mining techniques are specific for individual mines and will change with time as the ore is removed and the open pit is developed. Therefore, a comparison of the radon release from two different mines should include the mining procedures used, the age of the mine, and the mine size.

The St. Anthony Mine, selected for this study, is located about 60 miles northwest of Albuquerque on the old Spanish Cebolleta land grant. Exploration in the St. Anthony area began about 1964 and stripping started in 1975. The mine complex consists of an operating open pit, an inactive open pit, and a developing underground mine. The St. Anthony Mine is near the largest open pit uranium mine in the United States, Jackpile, operated by the Anaconda Company; it is also adjacent to the Sohio Mine and Uranium Mill (Figure 1). North of these mines are the foothills of Mount Taylor, an extinct volcano with an elevation of 11,700 feet. The area is a southern section of the Colorado Plateau which is extensively covered with igneous rock. Most of the lava from Mount Taylor covered an erosion plane developed over Cretaceous rock.

At the St. Anthony Mine site, the upper formations are Dakota and Lower Mancos Shale. Erosion of the softer rock has left numerous volcanic necks standing above the surrounding land, forming valleys and arroyos (Figure 2) and exposing ore deposits in several locations. The Morrison Formations (Figure 3) are in ascending order: Recapture Member, Westwater Canyon Member, and Brushy Basin Member. The ore deposits are generally contained in the upper part of the Brushy Basin Member, in so-called Jackpile sandstone (Hilpert and Freeman 1955). The topography of the St. Anthony Mine site, with an extensively eroded mesa, is shown in two aerial photographs, Figures 1 and 4; Figure 4 also shows the location of the meteorological and air monitoring stations. Figures 5 and 6 show the active mine pit, overburden, and secondary mine waste deposits. 


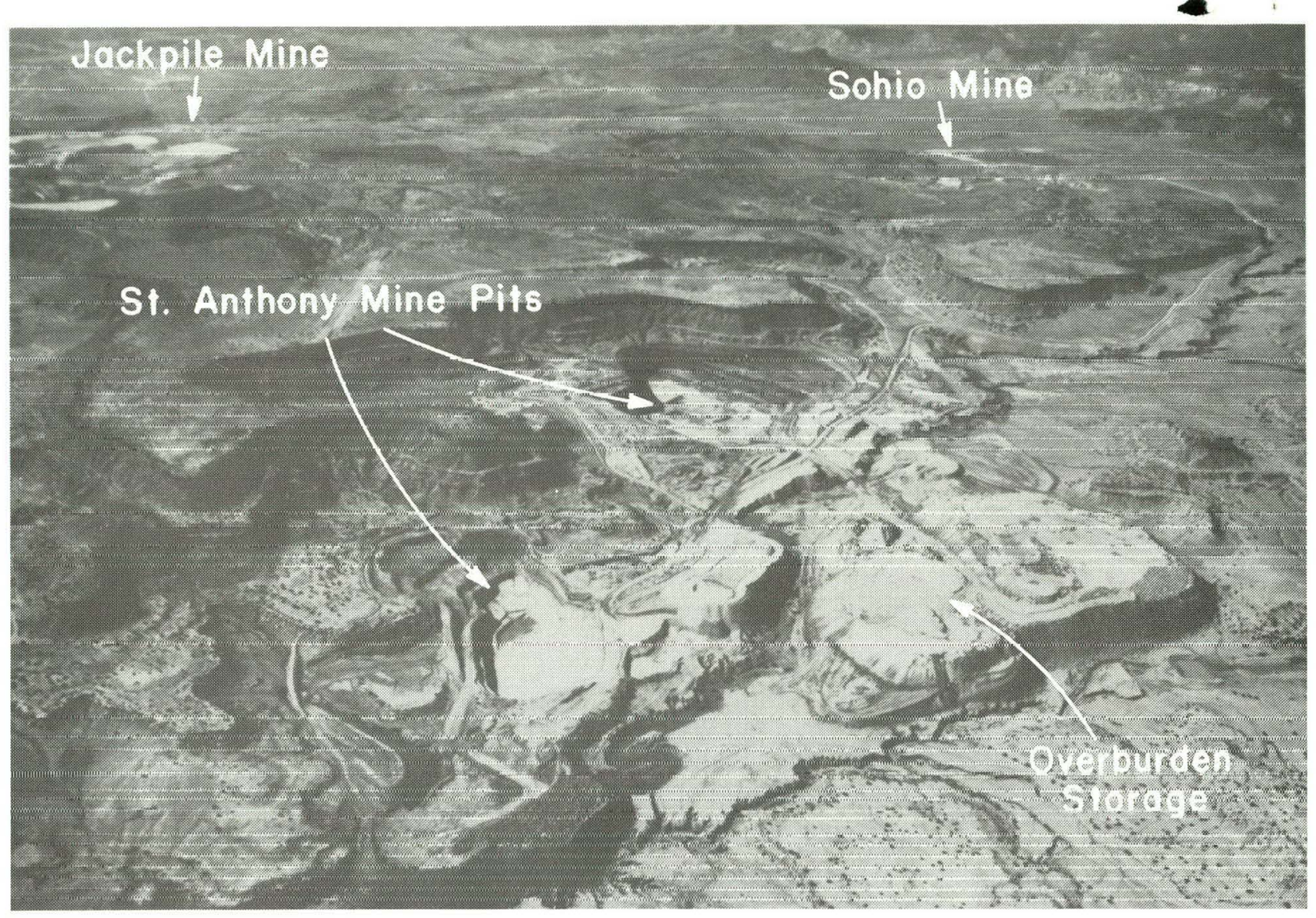

Figure 1. Aerial Photograph of the St. Anthony Mine Region.

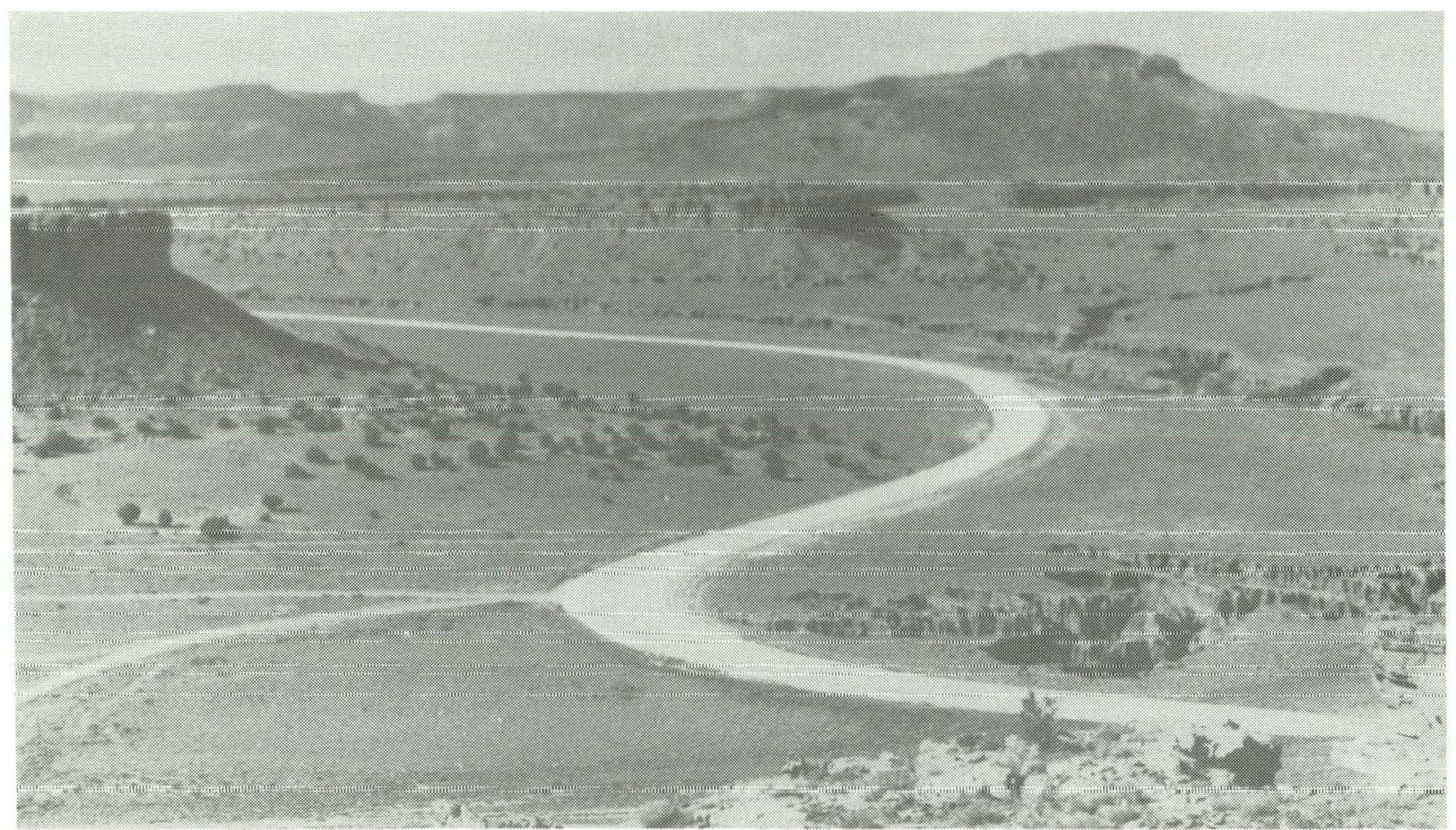

Figure 2. View of the St. Anthony Erosion Plane. 


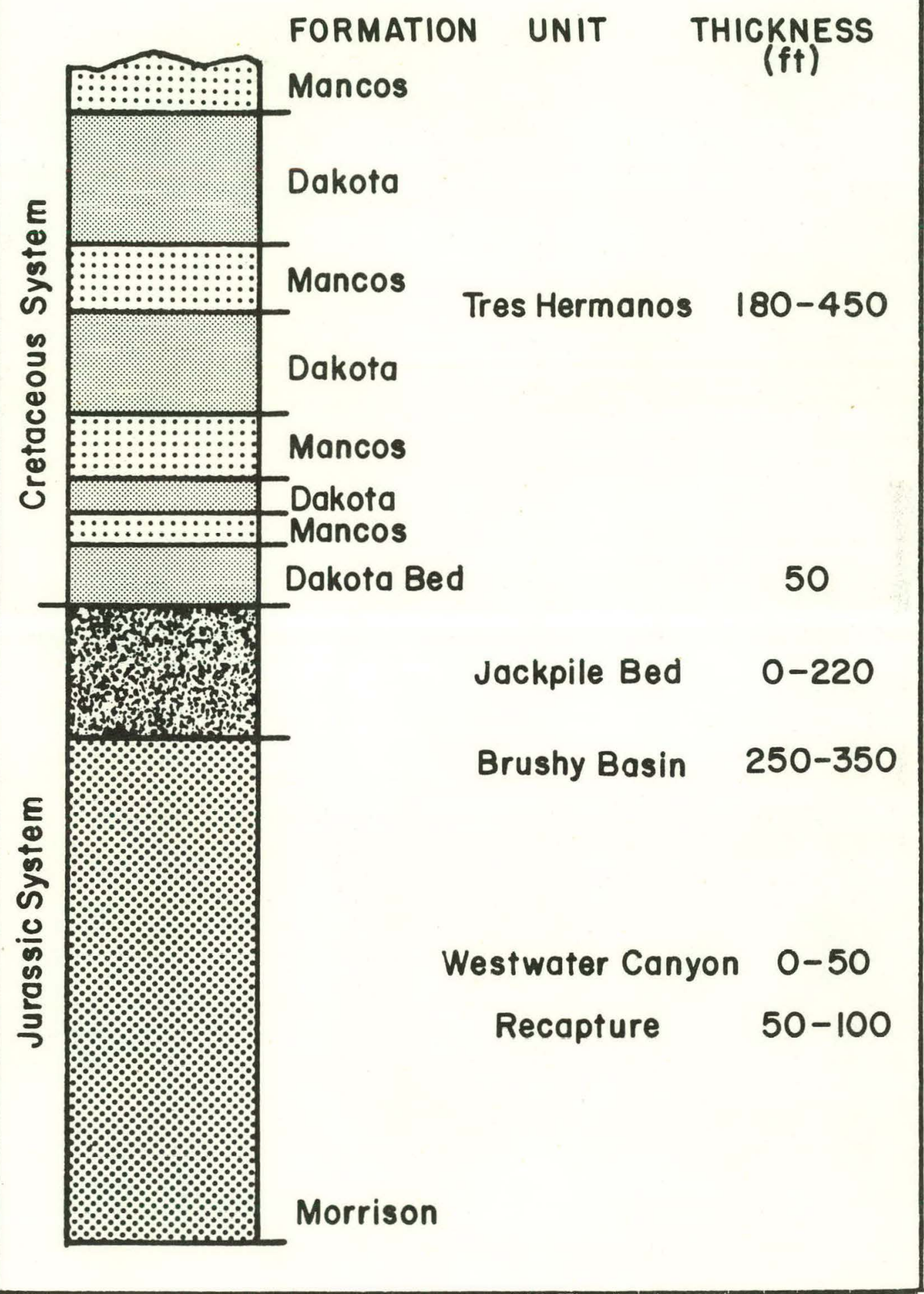

Figure 3. Geological Cross Section of the Morrison Formation. Redrawn from Hoppe (1978) (with permission of McGraw-Hill Book Co., Inc.). 


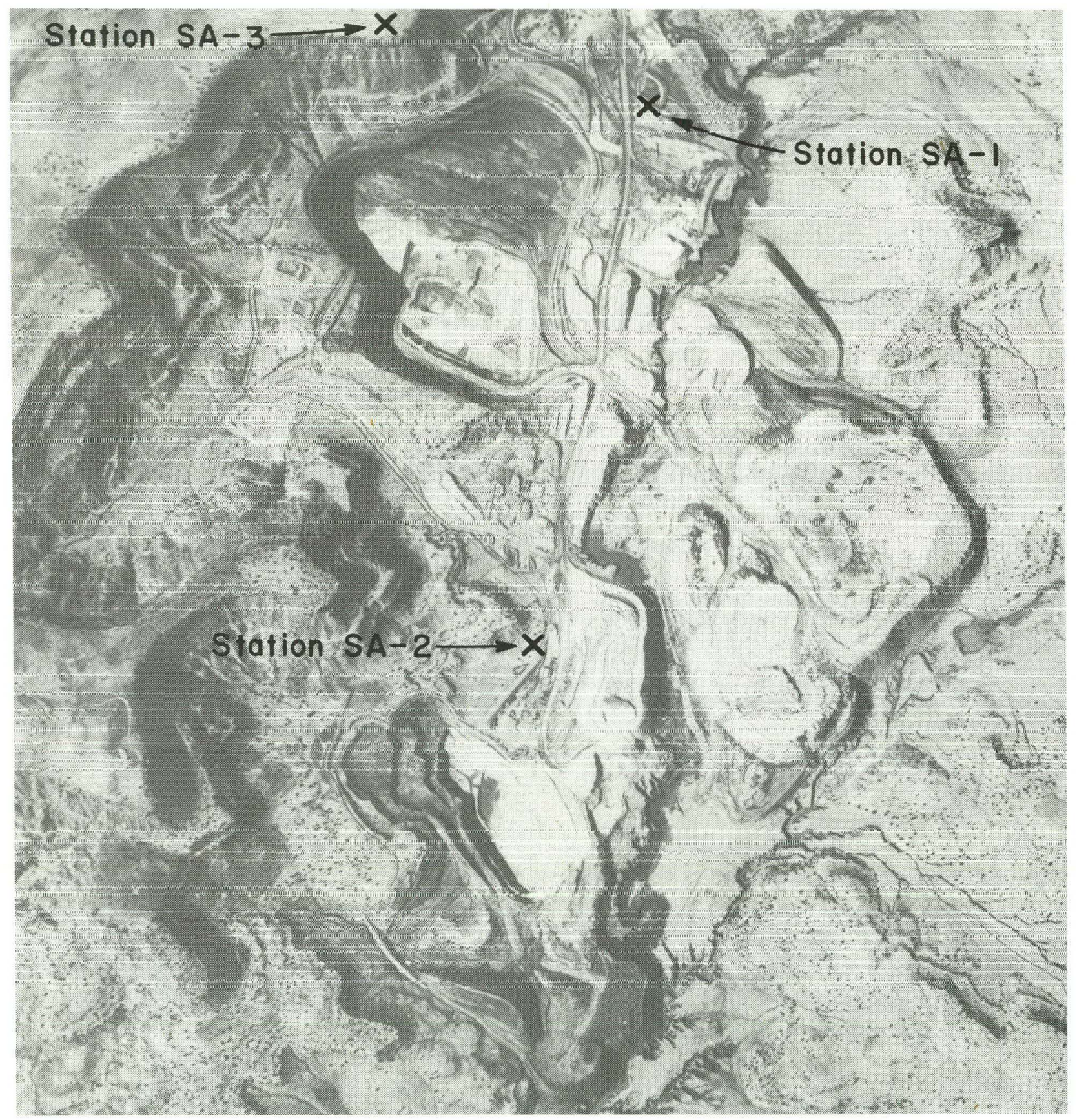

Figure 4. Aerial Photograph Showing St. Anthony Mine Topography and Monitoring Stations. 


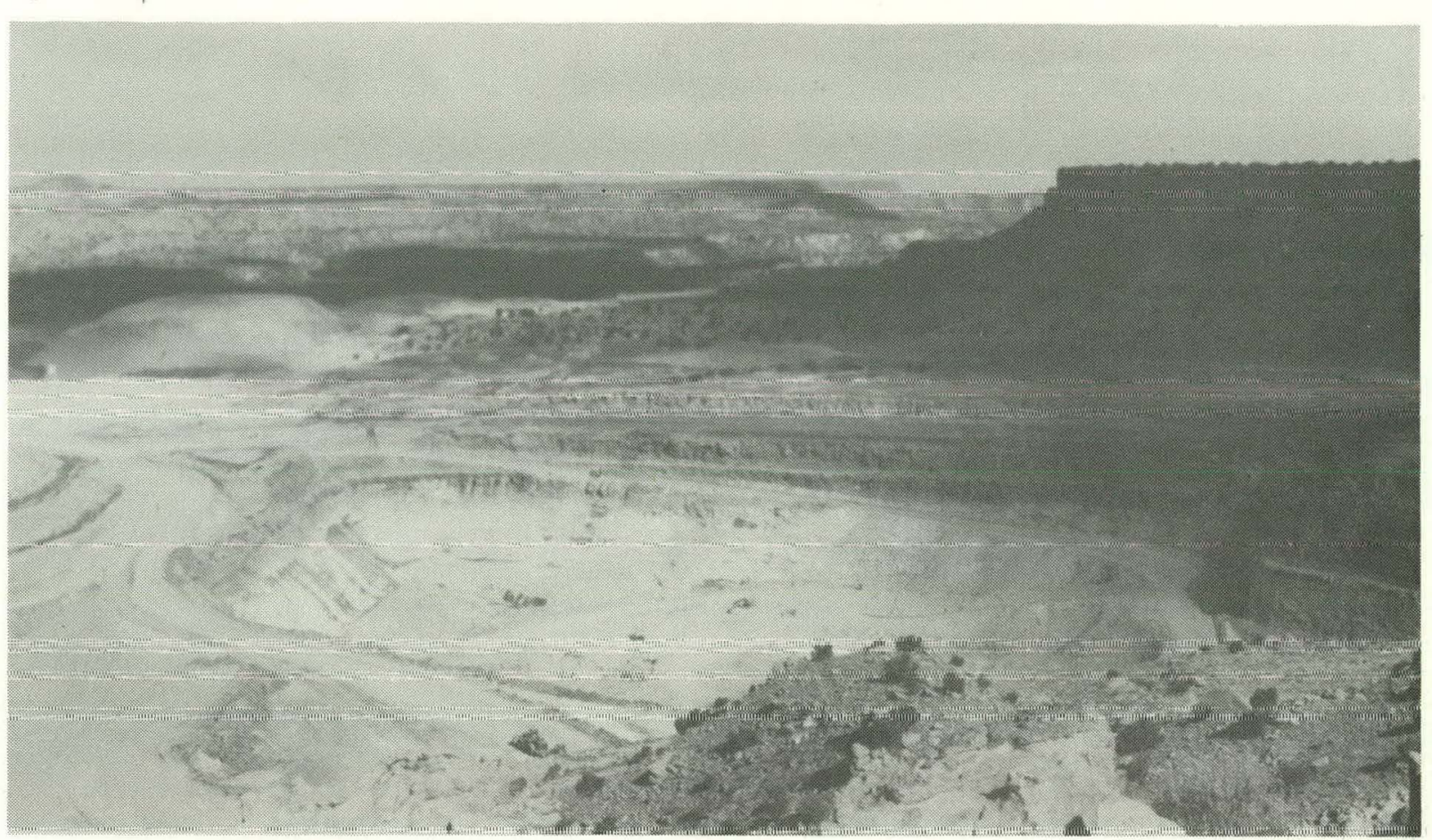

Figure 5. View of Active Open Pit.

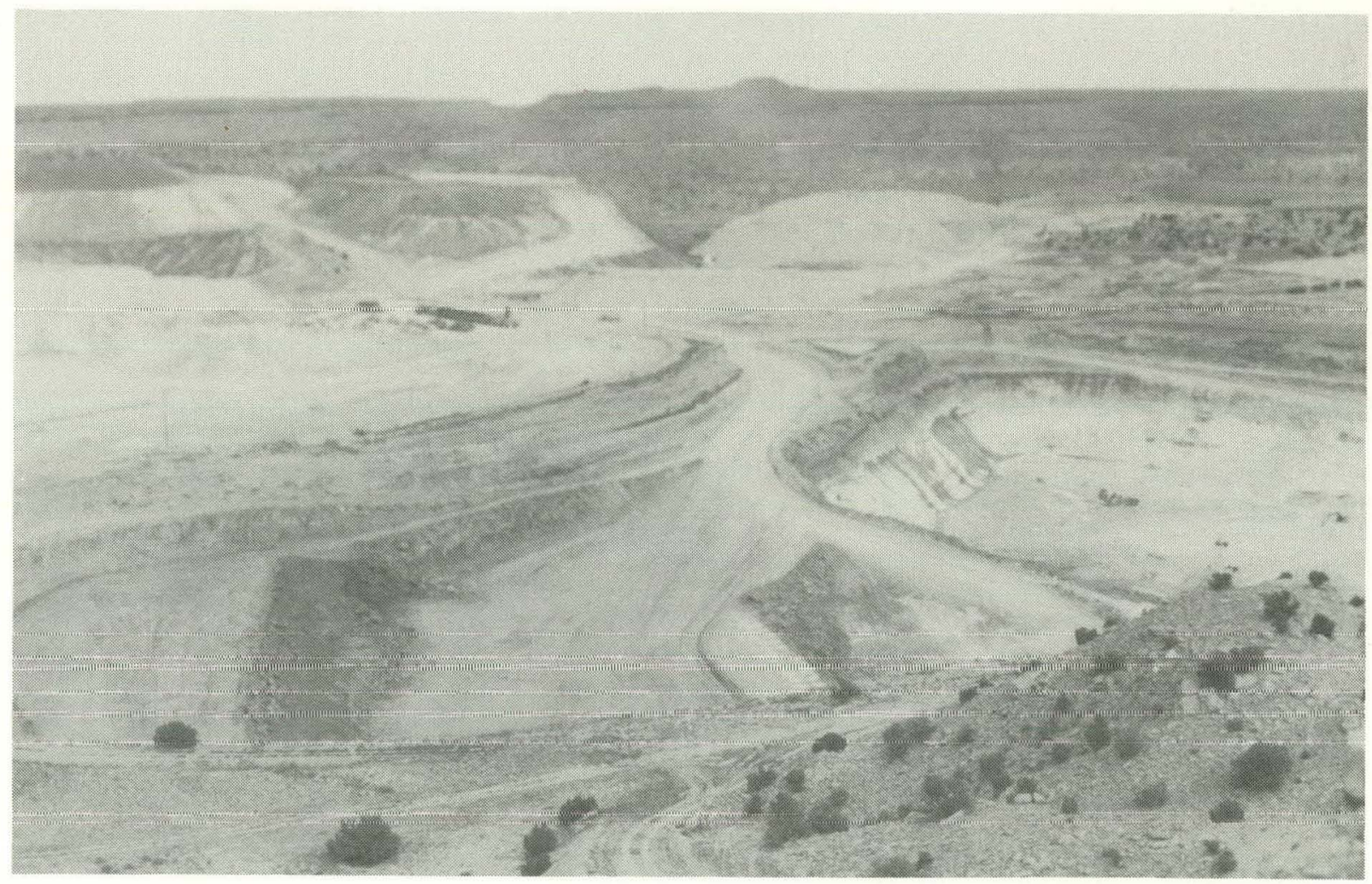

Figure 6. View of Overburden and Secondary Waste Deposits. 
To meet the main tasks outlined in the foreword, the following studies were initiated:

1. Measurement of meteorological conditions that affect both radon release and dispersion.

2. Determination of radon $(\mathrm{Rn}-222)$ release rates from different areas within an open pit uranium mine.

3. Measurement of the inherent parameters controlling radon release rates.

4. Determination of radon and radon daughter concentrations in the atmosphere within the mining area and the vicinity (background).

5. Development of theoretical methods for estimating radon release.

\section{METEOROLOGY}

Radon release and dispersion are affected by site-specific meteorological conditions. Because topography and elevation affect temperature, dew point, wind speed and wind direction, these four parameters were measured at the mine. Changes in atmospheric pressure are not significantly affected by local topography; therefore, pressure data from the Environmental Data Service Station in Albuquerque were used for this study.

The parameters of wind speed and wind direction were measured with a WM III (Climatronics Corporation) system, which includes a three-cup anemometer and a wind vane. The minimum wind velocities required to activate the anemometer and wind vane, respective1y, were 0.25 and $0.12 \mathrm{~m} / \mathrm{s}$.

The temperature was measured by an aspirated thermistor protected from direct sunlight; a fan provided a constant air flow through the shield. The vertical temperature profile $(\Delta \mathrm{T})$ was measured using two sensors, one at $3 \mathrm{~m}$ and the other at $30 \mathrm{~m}$ above the ground. A dew point sensor for the measurement of relative humidity was also incorporated with one of the shielded thermistors.

Atmospheric stability was determined from the standard deviation of the horizontal wind direction, using a sigma translator.

The weather sensors were mounted on two towers at the mine: a 10-m tower about $100 \mathrm{~m}$ east of the mine entrance in the valley (St. Anthony Station 1, SA-1); and a 30-m tower erected on top of the mesa on the west side of the valley, overlooking the mine complex (SA-3). The distance between the two towers is slightly less than a kilometer. The 30-m tower is equipped with a lightning rod for protection of the electronic equipment. Figure 7 shows the $30-\mathrm{m}$ tower during installation of the sensors, and Figure 8 shows the sensors mounted at the 3-m level and the shed containing the electronic equipment. 


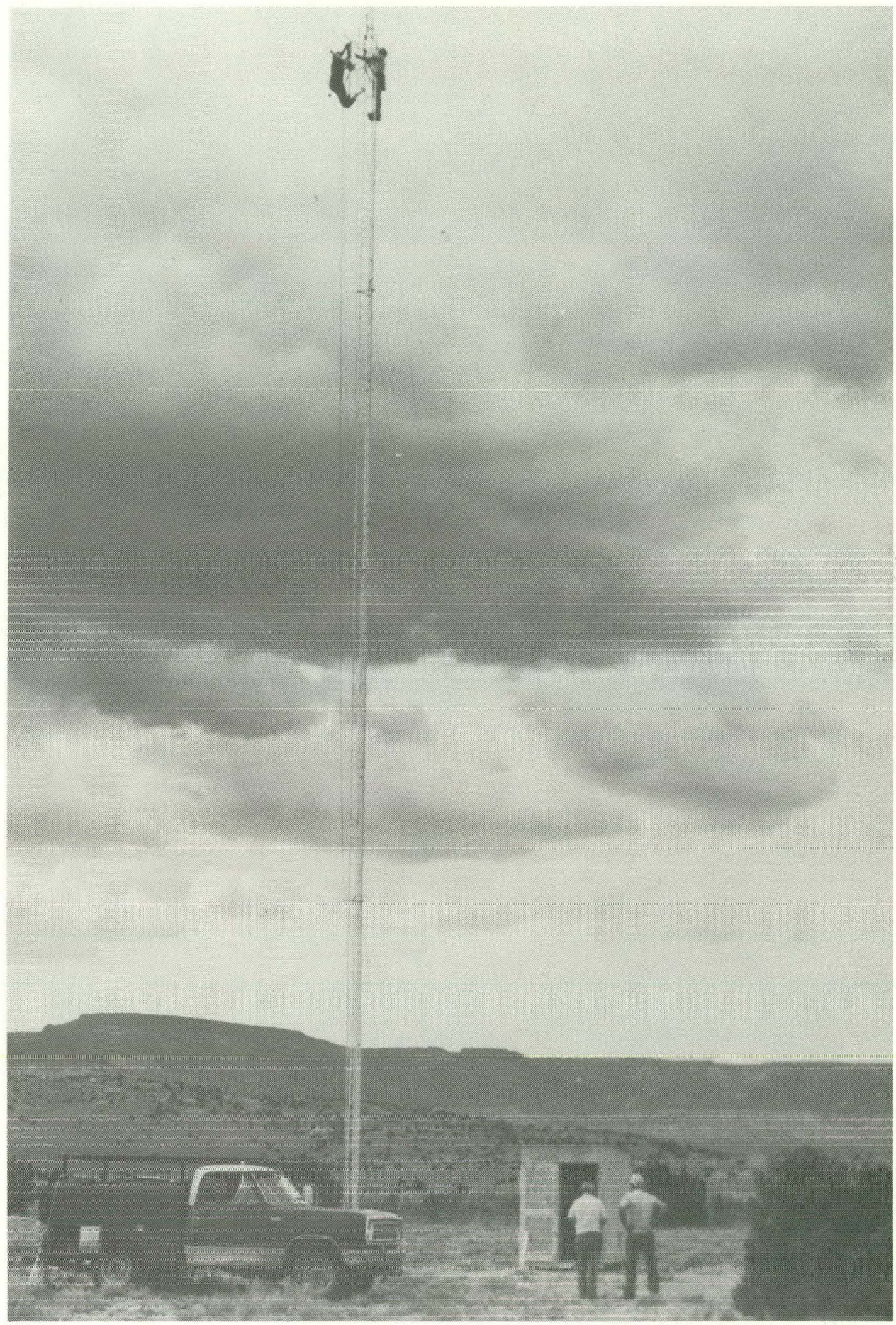

Figure 7. Installation of the 30-m Meteorological Tower. 


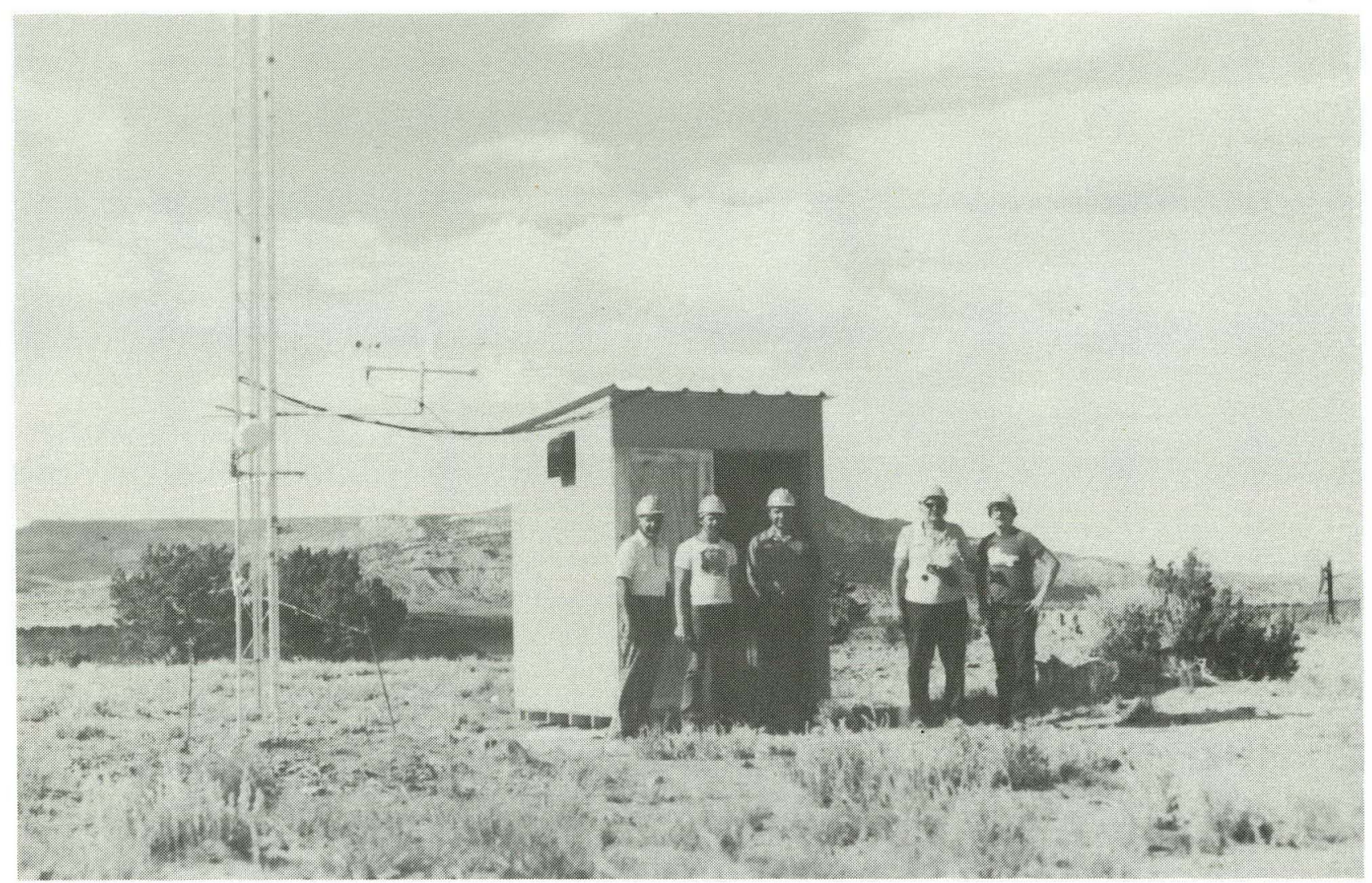

Figure 8. Meteorological Equipment at Station SA-3.

The primary data-logging device for each meteorological station is a Cassette Data Acquisition System (CDAS). The CDAS records the day, time, and meteorological data on a magnetic cassette tape. An analog backup system consisting of a multiplex recorder was installed in case the CDAS failed. Each multiplex recorder was capable of plotting three parameters on pressuresensitive strip chart paper. Because of the large number of parameters collected at SA-3, two recorders were used at that station.

The air movement through the mine valley was followed using a smoke bomb released at the edge of the mesa. A strong upward air motion that occurs in the late afternoon is shown in Figure 9. During the evening hours, the air flow reverses itself with the onset of cold air drainage.

Dust released from overburden blasting is also a visible indicator of the air flow patterns in the valley. Figures 10a through 10d are sequential pictures taken from the mesa following a detonation. These observations could be utilized to compare specific wind conditions to dust dispersion in the valley.

The meteorological data measured at the St. Anthony Mine are summarized in Appendix A, Tables A.1 through A.14. Daily maximum and minimum temperature, along with daily averages of temperature, wind speed, and dew point are presented. A comparison of these data with data from the International Airport 


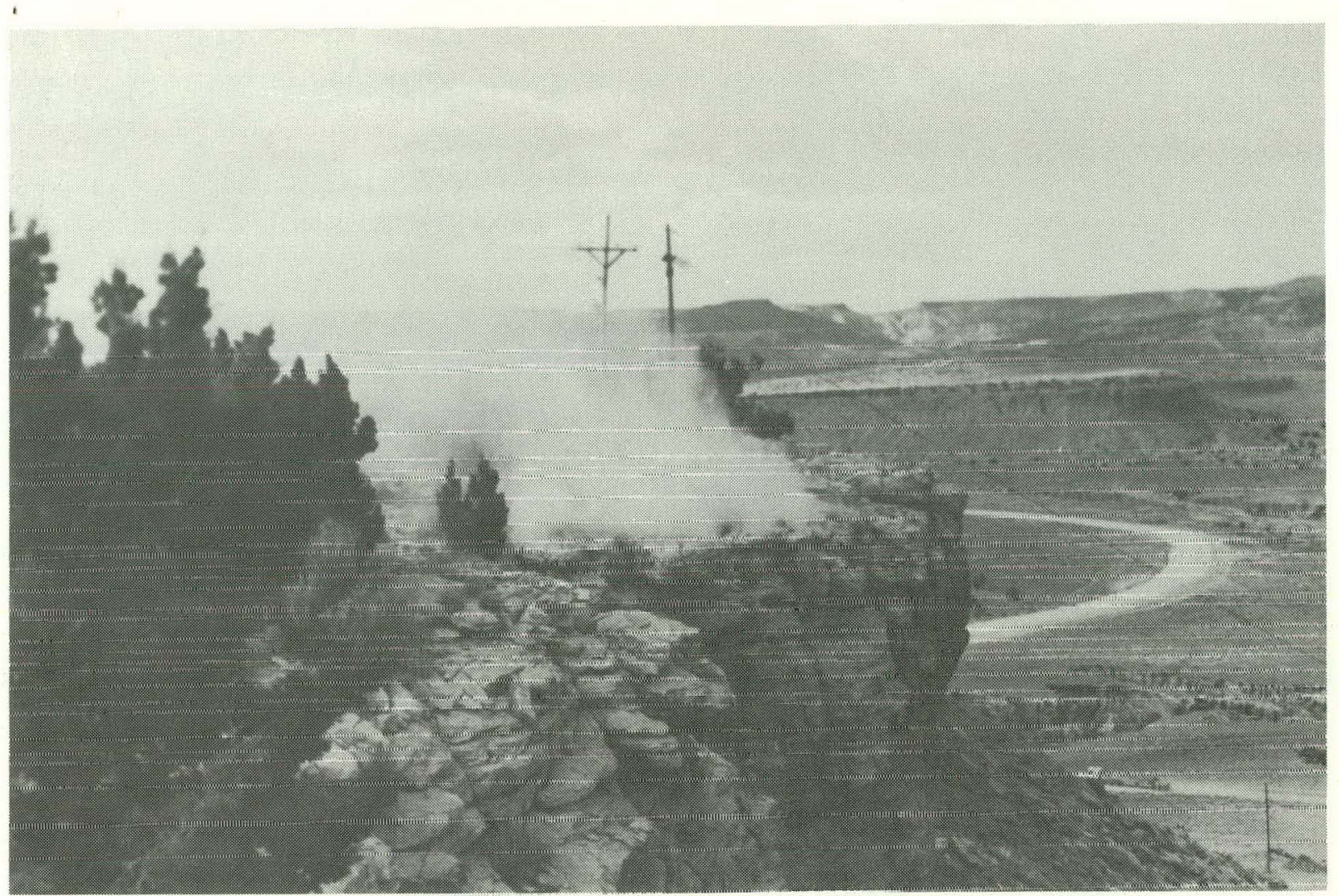

Figure 9. Smoke Showing Upward Air Motion.

(Albuquerque) shows the necessity for onsite meteorological data. The daily average wind specd at the mine was sometimes a factor of three lower than that at the airport. The variation in hourly wind direction between the upper and lower levels of the $30-\mathrm{m}$ tower is indicative of the effects caused by local terrain. These effects would not be apparent from wind direction information recorded at the Albuquerque airport. The dew point at the mine was always lower, indicating a drier climate. The maximum daily average temperature difference was $3^{\circ} \mathrm{C}$.

\section{SELECTION, I'ESTING, AND CALIBRATION OF THE RADON FLUX MEASUREMENT SYSTEM}

To study radon flux from the ground over an area as large as an open pit mine, a sensitive and cost-effective method of collecting and measuring radon is needed. A method previously used by Countess (1977) seemed most applicable Lo this need. In this method, military gas mask canisters containing activated coconut charcoal were positioned on the ground to collect radon released from the surface. Dewar (1903) reported on the ability of activated coconut charcoal to adsorb and hold inert gases. Rutherford (1906) and Boyle (1907) used charcoal to study thorium and radium emanations. 

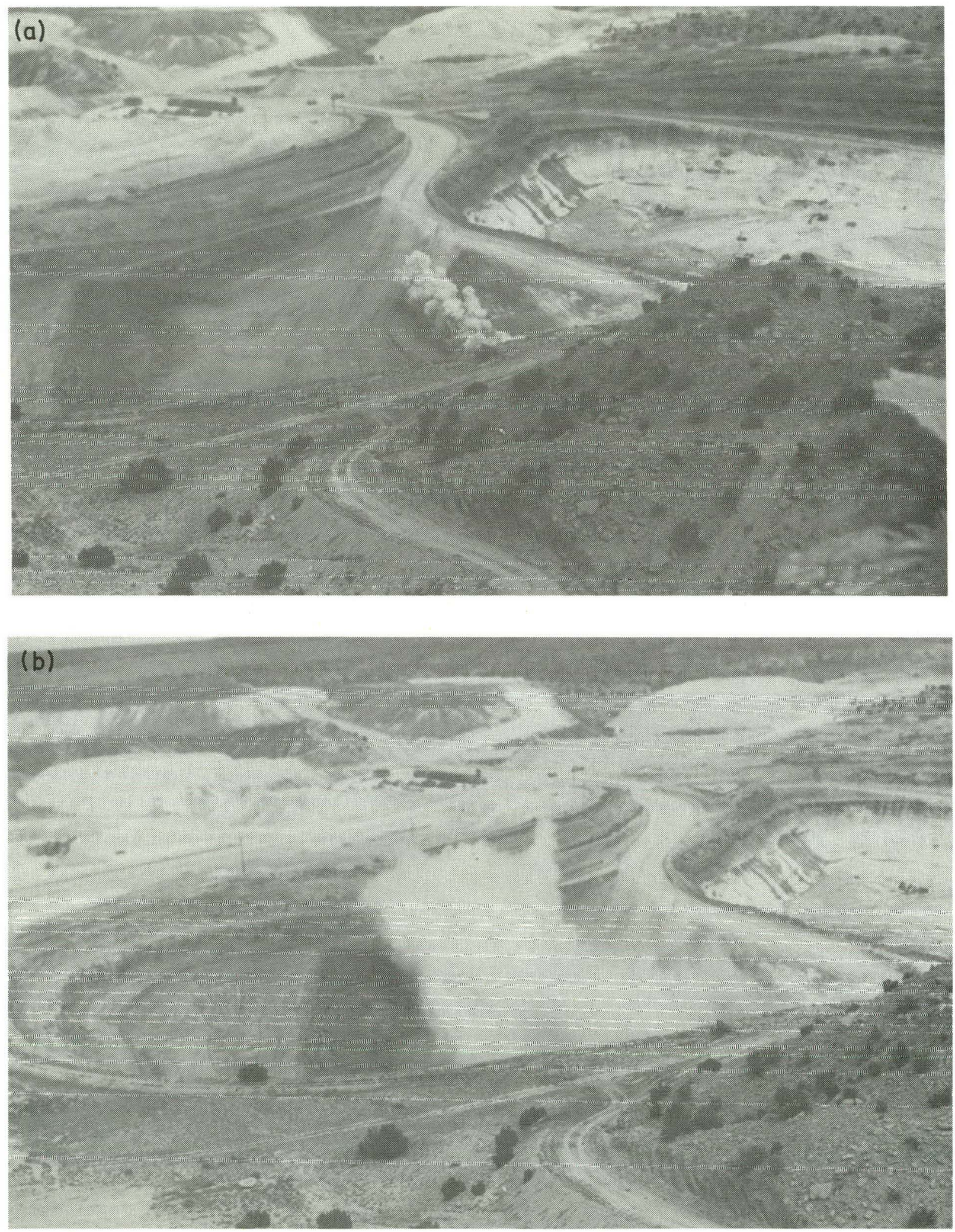

Figure 10. Sequential Pictures of Smoke and Dust from Blasting (time elapsed, approximately 3-4 minutes). 

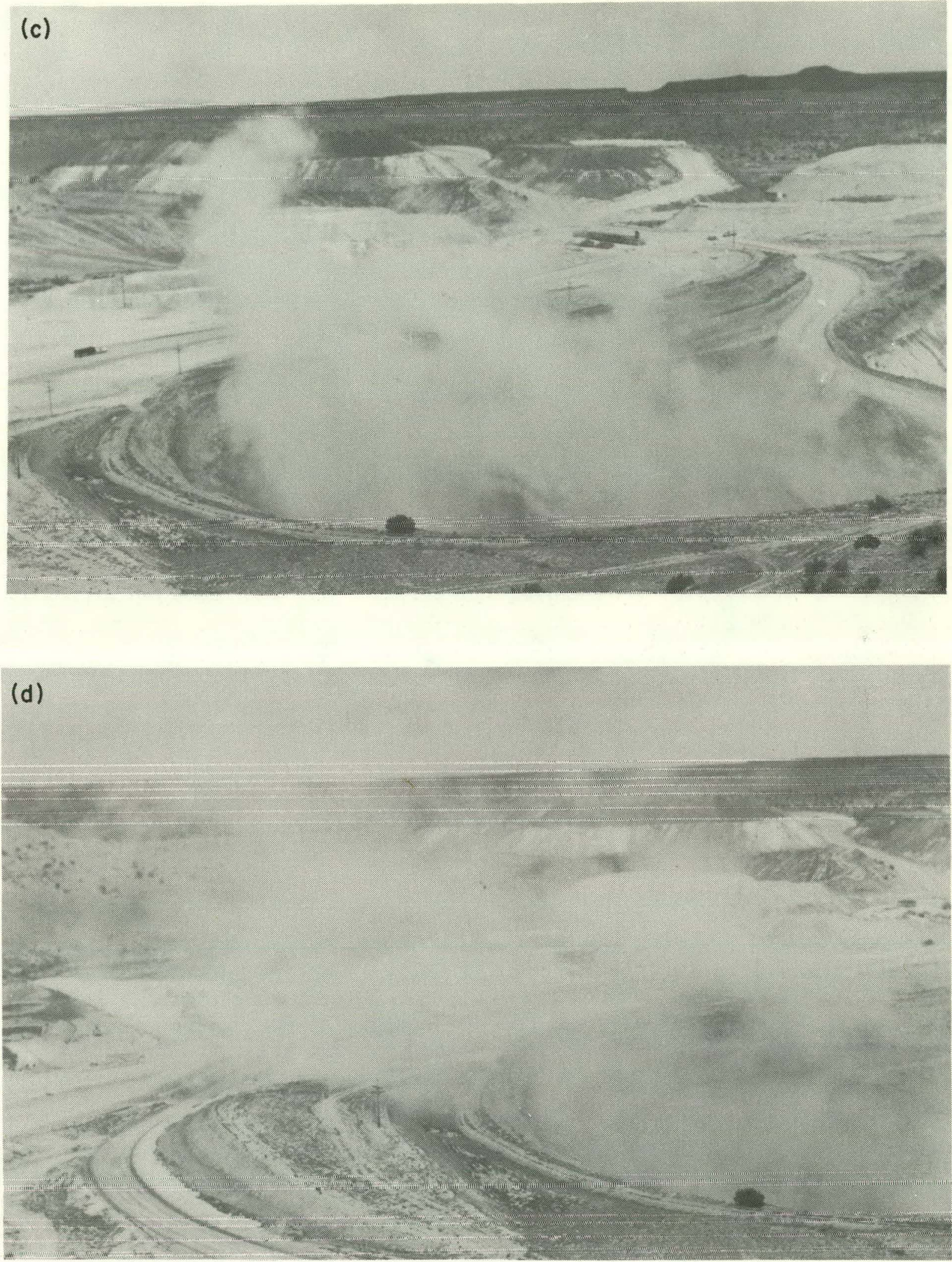

Figure 10. (Continued). 
After collection, the activity in the canister is determined by measuring the gamma-ray intensity of the radon daughters. To establish the efficacy of using this method for measurements of radon flux density, the canisters were tested under laboratory conditions. These tests were designed to answer the following questions:

1. What is the radon collection efficiency of the activated charcoal in these canisters?

2. What is the variation in collection efficiency between canisters?

3. Can radon be cleared from the canisters, and are these canisters usable after clearing?

\section{RADON TEST SOURCE FOR CANISTER EXPOSURE}

A radon bubbler assembly (Figure 11) was utilized to expose the activated charcoal filters to a determined quantity of $\mathrm{Rn}-222$. The Ra-226 in the bubbler solution decays to radon, and a constant $\mathrm{flow}\left(10 \mathrm{~cm}^{3} / \mathrm{min}\right)$ of nitrogen gas is bubbled through the solution, carrying with it a fraction of the radon. This process is called de-emanation. With continued bubbling, the radon production and de-emanation rates equilibrate and a constant flow of radon is obtained. A canister is attached to the assembly and the charcoal filter is allowed to adsorb radon for a measured exposure interval ( $t)$. The total radon exposure $(\mathrm{Rn})$ is determined by the following formula:

$$
\operatorname{Rn}=\operatorname{Ra} \times \lambda \times t
$$

where: $\mathrm{Ra}=\mathrm{Ra}-226$ activity in $\mu \mathrm{Ci}$,

$$
\begin{aligned}
& \lambda=\text { decay rate of } \mathrm{Rn}-222 \text { in reciprocal minutes, and } \\
& t=\text { exposure interval in minutes. }
\end{aligned}
$$

\section{GAMMA-RAY INTENSITY MEASUREMENT}

After exposure, the canisters were stored for at least 3 hours to allow Bi-214, a gamma-ray emitting daughter, to attain secular equilibrium with Rn222. The measurement of Bi-214 gamma-ray intensity was made with a $3 \times 3-i n$. NaI crystal detector coupled to a multichannel pulse-height analyzer. The canister, positioned in a shielded counting chamber, was centered on a line perpendicular to the detector face, with the geometric center of the charcoal filter at a distance of $10 \mathrm{~cm}$ below the detector* (Figure 12). The channel counts corresponding to the $0.609 \mathrm{MeV}$ gamma-ray of Bi-214 were summed for a total counting rate. This counting rate, corrected for background, was compared to that of an equilibrated Ra-226 standard to convert it to measured activity, expressed in microcuries. This measured activity was corrected for Rn-222 decay during the storage time to obtain a corrected activity ( $\mathrm{Rn}^{\prime}$ ) relative to the radon exposure $(R n)$.

*It was later found that changing radon distribution in the filter affected counting geometry. The method used to correct for this effect is presented in the section on Radon Distribution in the Charcoal Filter. 


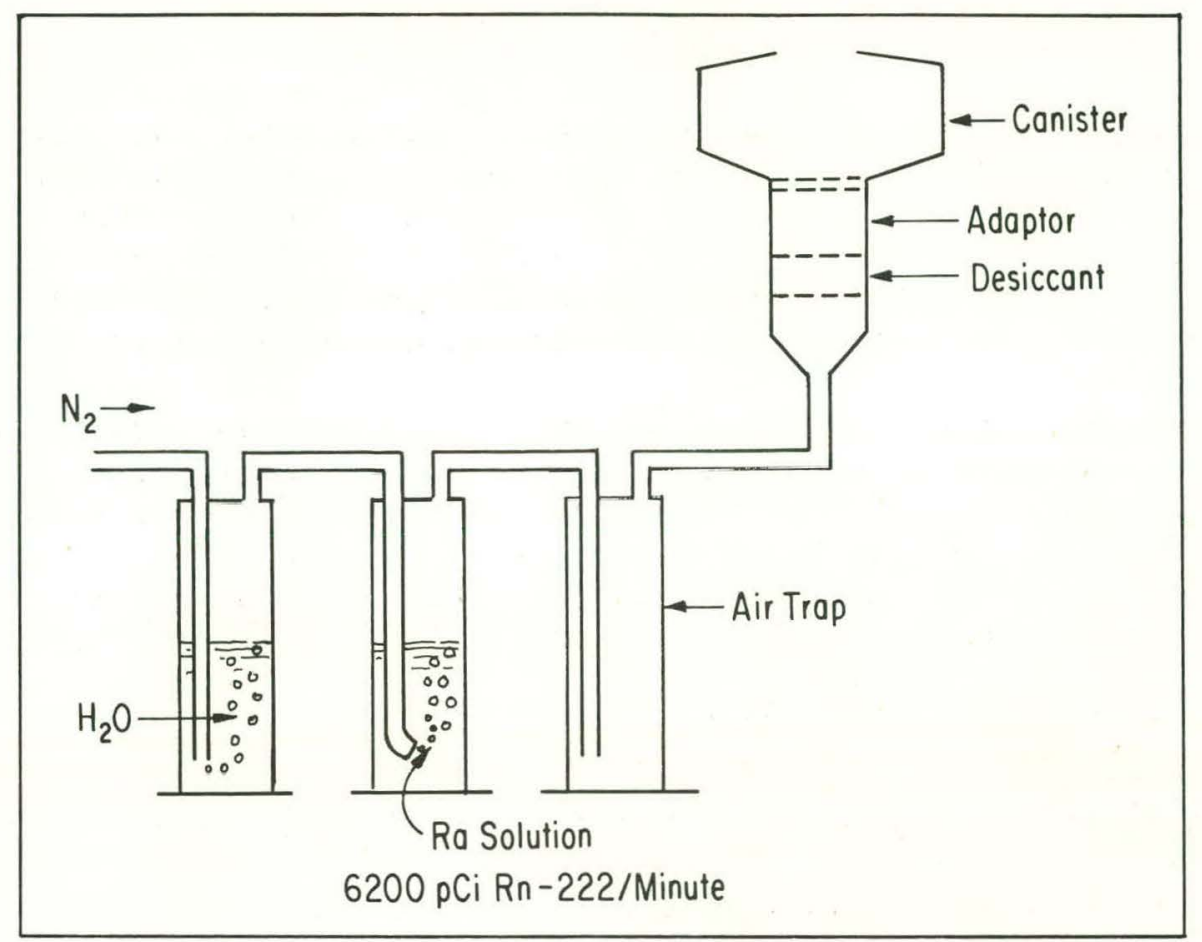

Figure 11. Schematic of Radon Bubbler Assembly.

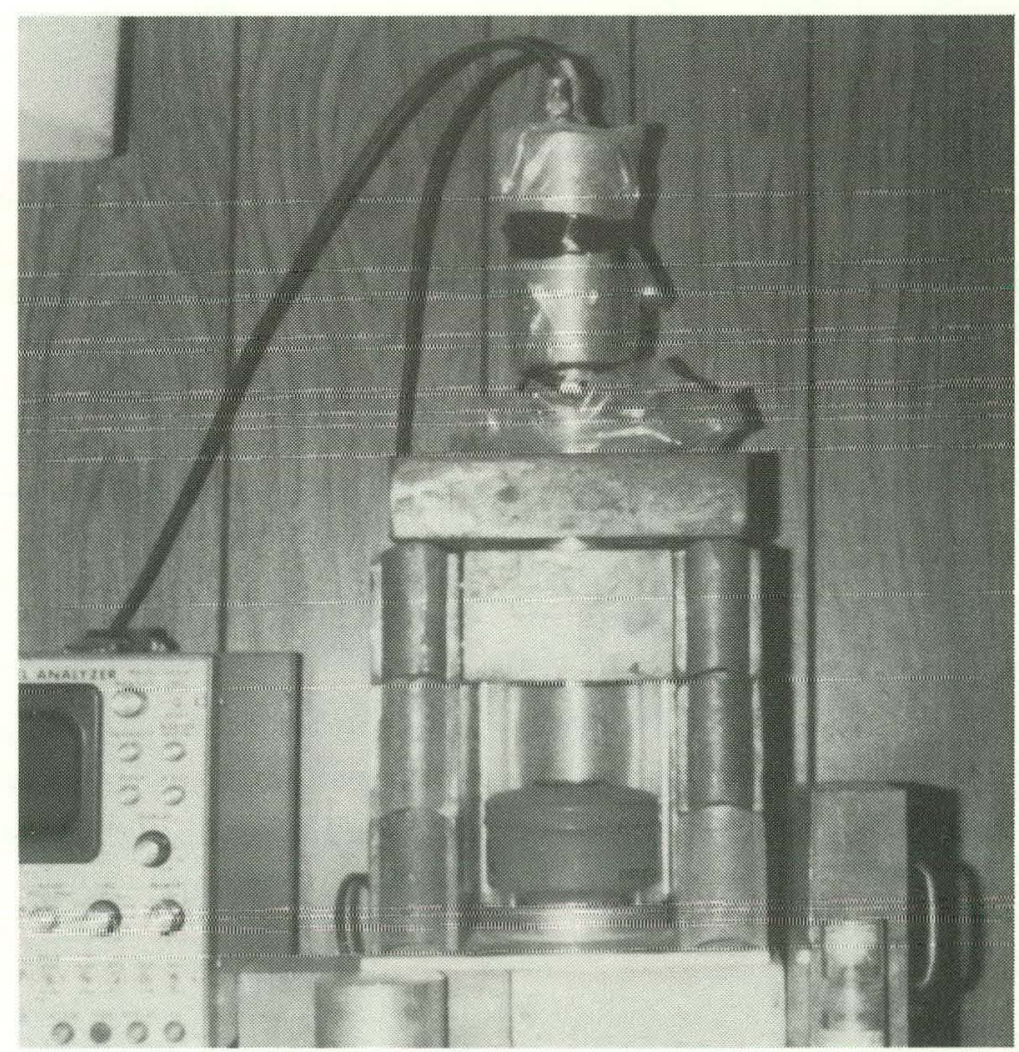

Figure 12. Gamma-ray Counting Chamber with Charcoal Canister. 


\section{CHARCOAL FILTER ADSORPTION EFFICIENCY}

Nine canisters were individually loaded with a determined quantity of radon $(\mathrm{Rn})$ by connecting them to the radon bubbler for an exposure interval of 5 minutes. After the appropriate storage time, each canister was counted and the corrected radon activity ( $\mathrm{Rn}^{\prime}$ ) calculated. Adsorption efficiency was defined as the ratio of $\mathrm{Rn}^{\prime}$ over $\mathrm{Rn}$, multiplied by 100 . The mean and standard deviation for the nine adsorption efficiencies was $94.5 \pm 6.4 \%$.

A second test of adsorption efficiency was performed with two canisters connected in series with an airtight seal to verify the results of the previous test. It was presumed that the radon not adsorbed by the first charcoal filter would be adsorbed by the second. If all of the radon was collected in the two filters, the net counting rates for the individual canisters could be used to determine the adsorption efficiency (e) of the first filter:

$$
e=\left[\mathrm{N}_{\mathrm{c}_{1}} /\left(\mathrm{N}_{\mathrm{c}_{1}}+\mathrm{N}_{\mathrm{c}_{2}}\right)\right] \times 100
$$

where: $\mathrm{N}_{\mathrm{C}_{1}}=$ net counting rate of the first canister, and

$\mathrm{N}_{\mathrm{c}_{2}}$ = net counting rate of the second canister.

Two sets of tandem canisters were loaded with radon. The first set was exposed for 30 minutes and the second set for 18 hours. After exposure, the tandem canisters were separated and individually counted. The adsorption efficiency determined for the set exposed for 30 minutes was $99.97 \pm 0.2 \%$; the adsorption efficiency for the set exposed for 18 hours was $99.11 \pm 0.03 \%$ * (average: 99.54\%).

The tandem tests showed that essentially all of the radon that enters the canister is adsorbed in the charcoal filter. Therefore, it was suspected that the lower estimate of adsorption efficiency (94.5\%) determined from the first test was due to the nonuniform distribution of radon in the charcoal filter.

\section{RADON DISTRIBUTION IN THE CHARCOAL FILTER}

The radon distribution in the charcoal filter was examined by making two different measurements of its gamma-ray intensity. The first measurement was made with the canister positioned as previously described, with the inlet side of the canister away from the detector. A second measurement was made after flipping the canister over. Care was again taken to keep the geometric center of the charcoal filter at a distance of $10 \mathrm{~cm}$ from the detector face.

Three canisters were loaded with radon and measured 7 hours after exposure by the flip method described above. A significant difference in the flip measurements (35\%) demonstrated that the inlet side of the filter had adsorbed more radon than the outlet side. The canisters were measured again at 32 and 72 hours after exposure. The ratio of the flip measurement, the net count of the second measurement divided by the net count of the first (plotted in Figure 13), shows that the radon distribution in the filter changes with time.

\footnotetext{
*This range was determined by the counting statistics of the second canister
} in each set. 


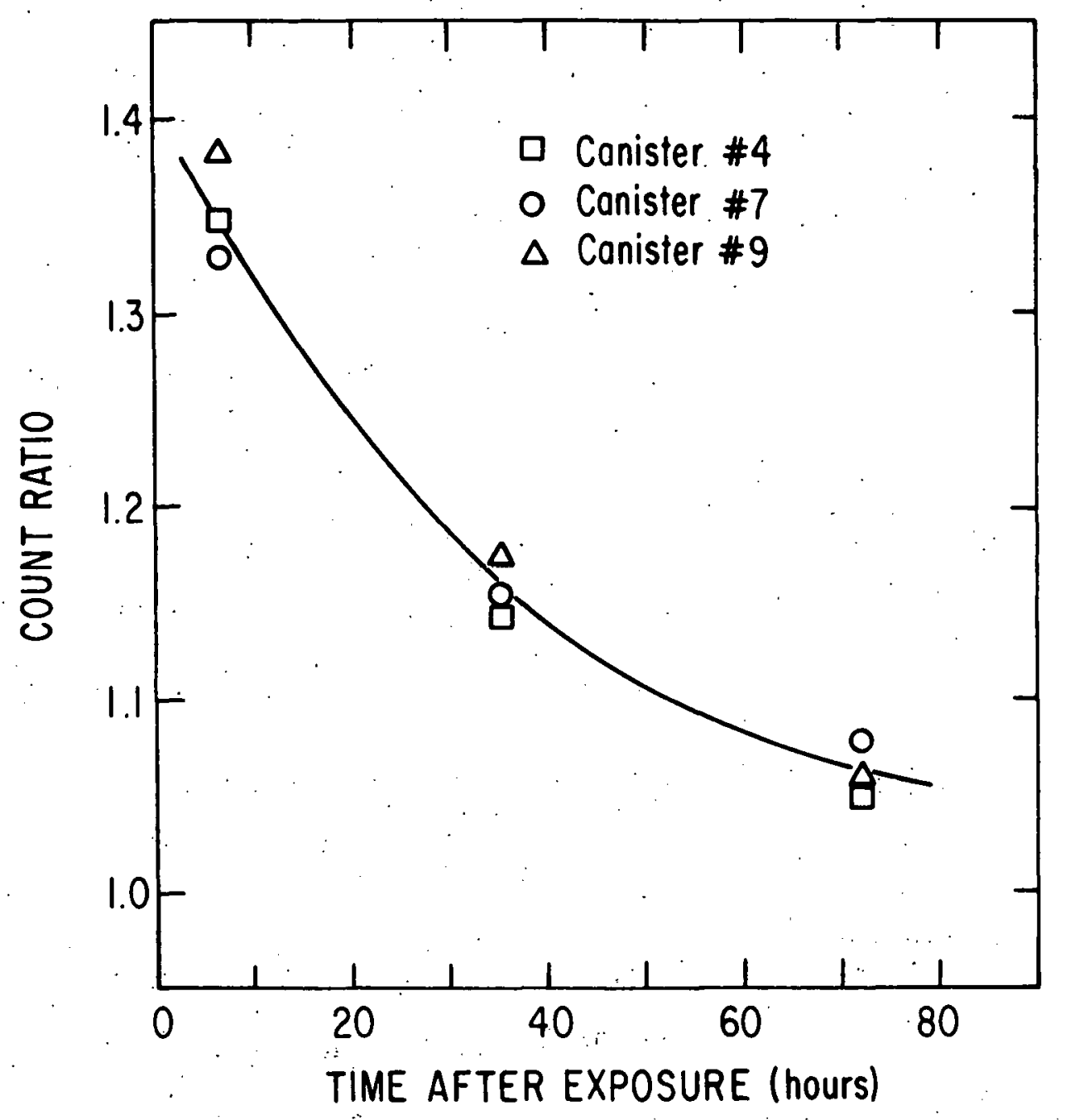

Figure 13. Plot of Radon Distribution in the Charcoal Filter.

This variation in distribution affects counting geometry and will cause a significant error in the activity determined at different times after. exposure. The flip counts were averaged in an attempt to compensate for the changing radon distribution: This average was used to determine the radon activity in the canisters at each of the postexposure times. The average radon activity values for the three canisters at each postexposure time, plotted on semilog graph paper (Figure 14), describe an exponential slope. This slope predicts an $\mathrm{Rn}-222$ decay rate with a radioactive half-life of 92.6 hours, which is in good agreement with the reported 91.8 hours.

To determine the mean adsorption efficiency and the variation expected using the flip count method, the individual canister activities were corrected for decay using the reported decay rate for $\mathrm{Rn}-222$ and the appropriate postexposure times. The nine values of corrected activity ( $\mathrm{Rn}^{\prime}{ }^{\prime}$ ) were compared to the radon exposure $(R n)$. The mean and standard deviation was $101.3: \pm 2.0 \%$. This adsorption efficiency is in good agreement with that obtained from the 


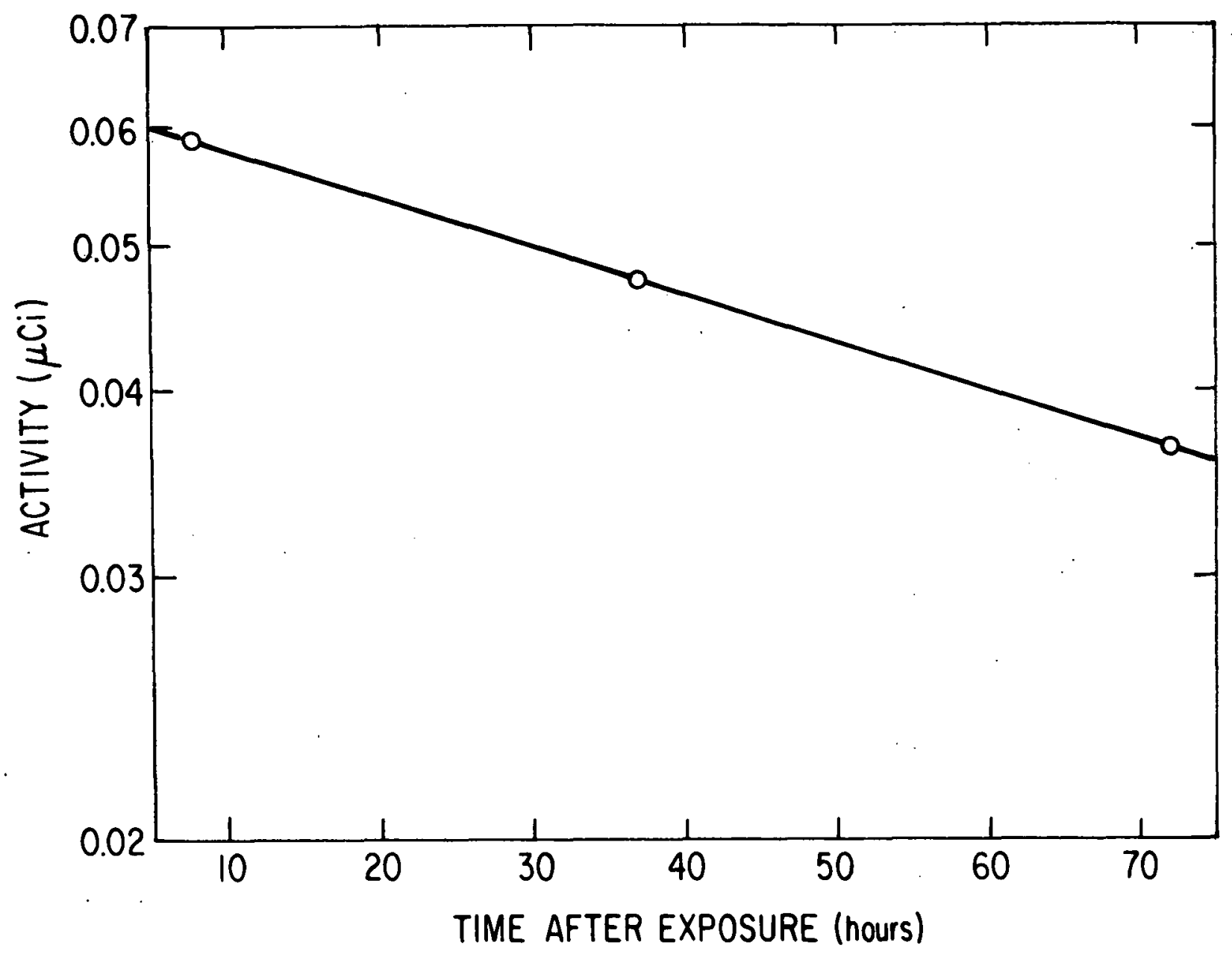

Figure 14. Exponential Decay of Radon-222 in the Canister.

tandem canister test, -and the standard deviation is significantly less than that determined with single counts.

This test demonstrated that the average of the flip counts would compensate for variations of radon distribution in the charcoal filter for counting delays of up to 72 hours. It also demonstrated that radon did not leak from the canister during this period. This improved counting technique was adapted for all future measurements.

\section{CANISTER CLEARANCE AND REUSE}

To adequately characterize the radon release from an extensive area such as an open pit mine, a large number of measurements are required. The cost of canisters and the logistics of transporting and storing a large number of them were two important reasons for examining the possibility of reusing the canisters. 
In previous studies where radon was collected on activated charcoal, the radon was subsequently released by heating the charcoal (Rutherford 1906). If Rn-222 could be cleared from the charcoal without affecting its collection efficiency, then the canister could be reused after the Bi-214 activity decayed. This decay rate is controlled by the $\mathrm{Pb}-214$ and $\mathrm{Bi}-214$ half-1ives. The storage time required to obtain a $99.9 \%$ reduction in activity is approximately 8 hours. Because this decay time is less than 24 hours, the total number of canisters needed to perform daily flux measurements at 10 locations would be $10 \times 2$, or 20 . This possibility could significantly improve the overall cost-effectiveness of the charcoal canister method.

In the first attempt to clear Rn-222, a small hot air gun consisting of a squirrel cage fan and an electric heating coil was used to blow heated air through the canister. The maximum clearance obtained with this system, with an air temperature of $150^{\circ} \mathrm{C}$ and a flushing interval of 20 minutes, was $68 \%$.

Testing of this system was discontinued for two reasons: (1) air temperatures above $150^{\circ}$ might damage the canister, and (2) flushing times longer than 20 minutes would limit the cost-effectiveness of reusing the canisters. The only viable option left was to increase the flow rate of hot air through the canister.

An improved Rn-222 flushing system (Figure 15) was constructed consisting of a shop-vac (Aquavac Model \#600), a 1200-watt heating coil, and two canister ports. This system had three advantages over the first system: (1) the air flow rate through the canister was much higher; (2) two canisters could be flushed at the same time, thus reducing the overall flushing time; and (3) air was filtered before it was forced through the canister, thus preventing dust from contaminating and clogging the charcoal filter. The temperature of the heating coil was controlled with a variable powerstat, and the air temperature was monitored with a calibrated thermocouple.

Two canisters containing radon were connected to the clearance system and flushed with $110^{\circ} \mathrm{C}$ air for a 10 -minute interval. The Rn-222 clearance determined for each canister was $100 \%$. To establish the optimum flushing time at $110^{\circ} \mathrm{C}$, five canisters were used, each flushed for a different interval. The Rn-222 clearance obtained for each interval was calculated and the results plotted as a function of flushing time (Figure 16). The maximum clearance $(100 \%)$ was obtained after 3 minutes. Because of varying line voltage and ambient air temperature conditions, 4 minutes was established as the optimum flushing time to ensure total clearance.

As stated previously, a canister could only be reused if the charcoal's adsorption efficiency was not affected by flushing. To determine the efficiency after flushing, three canisters previously cleared for intervals of 4 , 6 , and 8 minutes were exposed to the radon bubbler. They were counted by the flip method and their adsorption efficiencies determined as previously described. The mean and standard deviation of these efficiencies was $99.0 \pm 3 \%$. There was no measurable change in efficiency and, therefore, flushed canisters are reusable. 


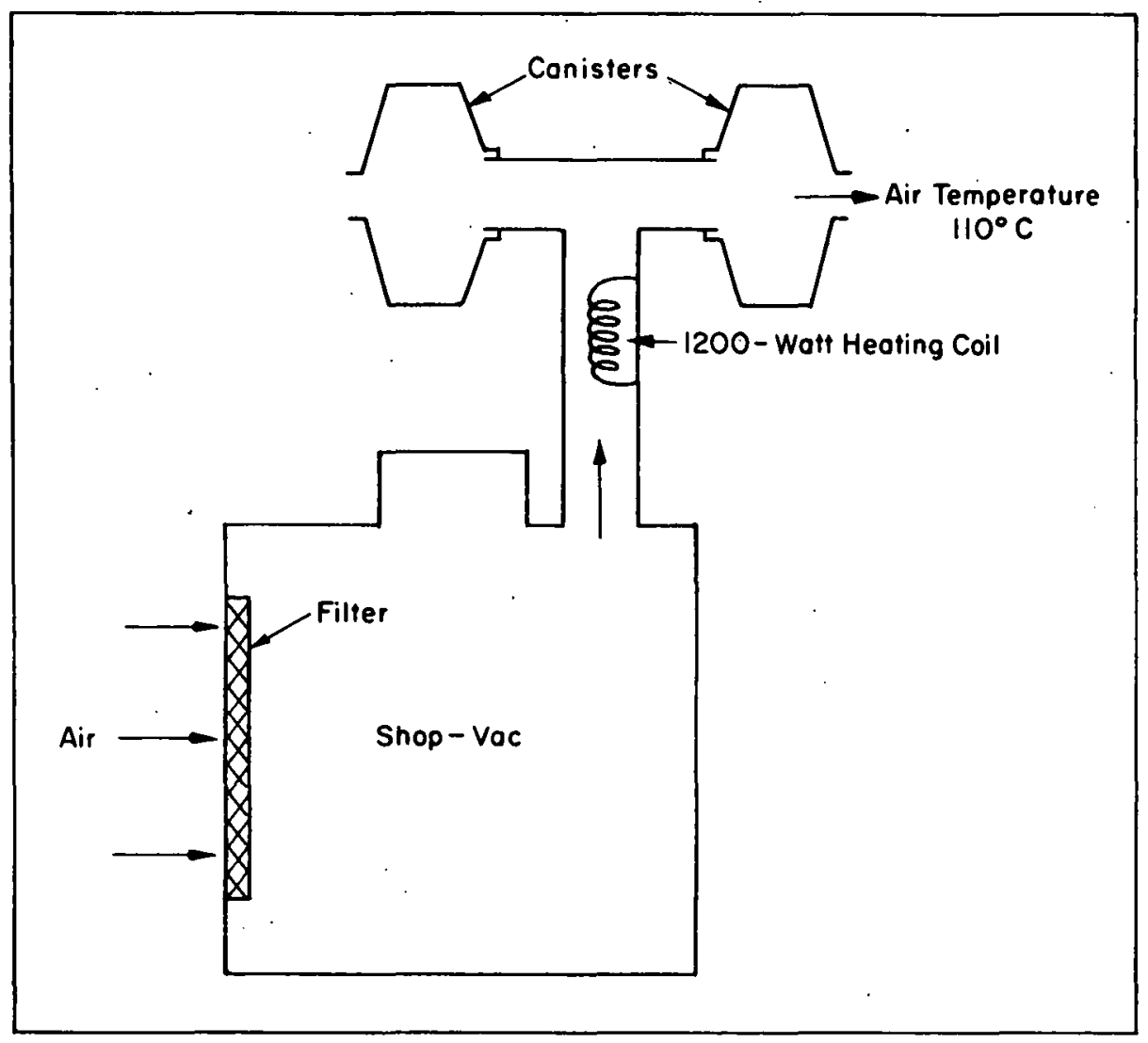

Figure 15. Schematic of Canister Flushing System.

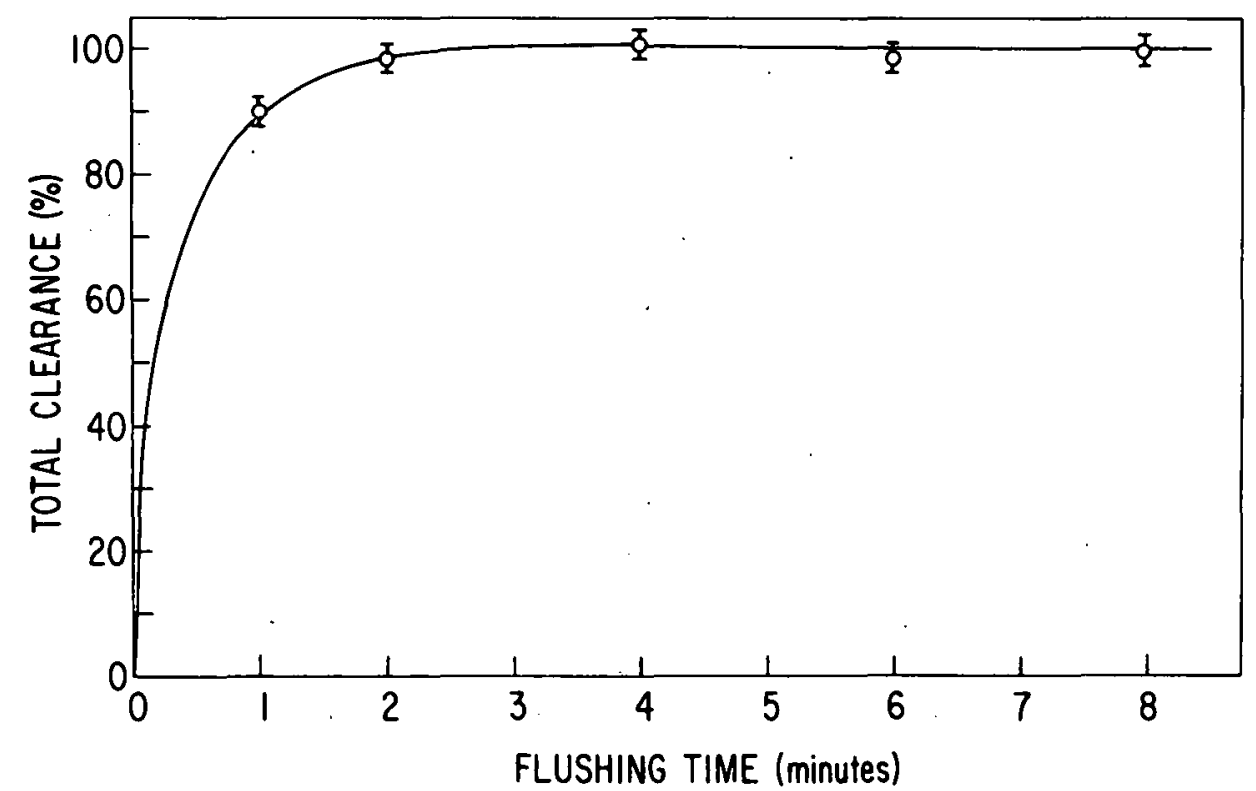

Figure 16. Radon Clearance as a Function of Time. 
In summary, the following conclusions were derived from the laboratory tests with charcoal canisters:

1. The Rn-222 adsorption efficiency of the charcoal filters in these canisters is about $99.0 \%$.

2. The collected $\mathrm{Rn}-222$ is not uniformly distributed in the charcoal filter.

3. The Rn-222 distribution in a sealed canister changes with time after collection.

4. Once collected, the radon in the canister is effectively held.

5. The standard deviation of canister measurements can be reduced to approximately $\pm 3 \%$ by averaging the flip counts.

6. Radon can be totally flushed from the canisters by forcing hot air through the charcoal filter.

7. The adsorption efficiency of the charcoal filter is not measurably affected by the flushing procedure.

\section{COLLECTION AND MEASUREMENT OF RADON FLUX}

The rate at which radon $(\mathrm{Rn}-222)$ atoms enter the atmosphere across a unit geometric surface area of the earth is defined as radon flux density, commonly referred to as radon flux. The preferred units of flux are (atoms $\left./ \mathrm{cm}^{2} \cdot \mathrm{s}\right)$ and ( $\left.\mathrm{pCi} \mathrm{Rn}-222 / \mathrm{m}^{2} \cdot \mathrm{s}\right) *$. Radon flux is controlled by complex and dynamic mechanisms involving the inherent parameters of Ra-226 concentration and distribution in the soil; emanating power of the mineral species; porosity, density, and moisture of the soil; molecular diffusion; and atmospheric conditions of barometric pressure, wind speed, and temperature.

The modified radon collector designed for this study is schematically shown in Figure 17. A charcoal canister is connected to the collector base, which covers a ground area of $0.23 \mathrm{~m}^{2}$. A desiccant column retained between two stainless steel screens is used to absorb evaporating moisture that would otherwise condense on the charcoal filter. The open end of the canister, protected with a loose-fitting dust cover, allows for a passive response to variations in barometric pressure.

The collector base was set on the ground surface, and soil was packed around the edge to provide a seal. A canister was mounted on the collector for a measured interval $\left(t_{1}\right)$ and then removed; after a storage interval $\left(t_{2}\right)$, it was counted as previously described. Following measurement, the canister was flushed, stored for 24 hours to allow Bi-214 decay, measured to ensure that no activity remained, and used for the next flux collection.

${ }^{* 1}$ atom $/ \mathrm{cm}^{2} \cdot \mathrm{s}=0.57 \mathrm{pCi} / \mathrm{m}^{2} \cdot \mathrm{s}$. 


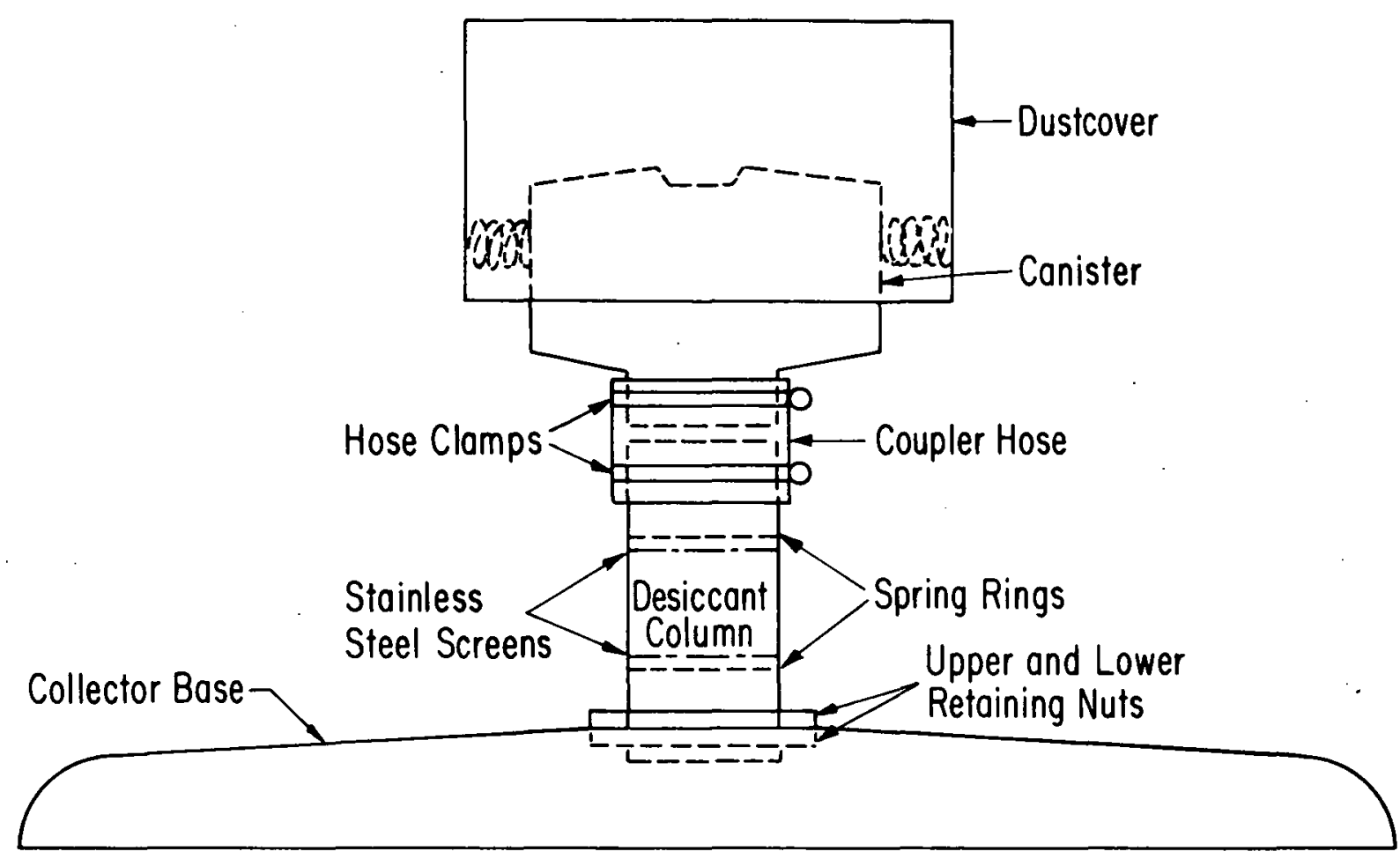

Figure 17. Schematic of Radon Collector.

The conversion from net counting rate (Nc) to radon flux density $(\Phi)$, in $\mathrm{pCi} / \mathrm{m}^{2} \cdot \mathrm{s}$, is as follows:

$$
M_{\mathrm{Rn}}(\mu \mathrm{Ci})=\frac{\mathrm{Nc}}{\mathrm{NS}} \times \mathrm{S}_{\mathrm{A}}
$$

where: $M_{R n}=$ measured radon activity in the canister $(\mu C i)$,

$\mathrm{Nc}=$ net count of canister,

Ns $=$ net count of Ra-226 standard, and

$\mathrm{S}_{\mathrm{A}}=$ activity of equilibrated Ra-226 standard ( $\mu \mathrm{C} i$ )

This activity was corrected for radon decay during the time interval $\left(t_{2}\right)$ :

$$
M_{R n}^{\prime}(\mu C i)=M_{R n} \times e^{\lambda t_{2}}
$$

where: $M_{R n}^{\prime}=$ total $R n-222$ activity collected in the canister $(\mu \mathrm{C} i)$,

$\lambda=\mathrm{Rn}-222$ decay rate (in hours ${ }^{-1}$ ), and

$t_{2}=$ time interval between collection and measurement (hours). 
The average radon collection rate $(\bar{Q})$, corrected for the incremental decay during the collection interval $\left(t_{l}\right)$, is:

$$
\bar{Q}(\mu \mathrm{Ci} / \mathrm{h})=\mathrm{M}^{\prime}{ }_{\mathrm{Rn}} \int_{0}^{\mathrm{t}_{1}} \frac{\mathrm{dt}}{\mathrm{e}^{-\lambda \mathrm{t}_{1}}}=\frac{\mathrm{M}^{\prime}{ }_{\mathrm{Rn}} \lambda}{1-\mathrm{e}^{-\lambda \mathrm{t}_{1}}}
$$

The conversion from the average radon collection rate to radon flux density is :

$$
\Phi\left(\frac{\mathrm{pCi}}{\mathrm{m}^{2} \cdot \mathrm{s}}\right)=\frac{\left(\overline{\mathrm{Q}} \frac{\mu \mathrm{Ci}}{\mathrm{h}}\right) \cdot\left(10^{6} \frac{\mathrm{pCi}}{\mu \mathrm{Ci}}\right)}{\left(3600 \frac{\mathrm{s}}{\mathrm{h}}\right) \cdot\left(0.23 \mathrm{~m}^{2}\right)}
$$

where: $0.23 \mathrm{~m}^{2}=$ ground area covered by the collector base.

\section{LOWER LIMIT OF DETECTION}

The NaI detector and counting chamber were enclosed in a 2-in. thick lead shield (Figure 18). This shield reduced the background counting rate in the Bi-214 energy range from 12.2 to 1.39 counts per second. The calibration factor, determined by the net counting rate of an NBS Ra-226 standard (Bi-214 peak) measured at $10 \mathrm{~cm}$ from the detector face, was 169.3 counts per second per microcurie.

If the lower detection limit is defined as a counting rate equal to two standard deviations of the background count rate, then the following formula can be used to determine this limit, based on an 800-second counting interval:

$$
\text { Lower detection limit }=\frac{2 \sqrt{\mathrm{C}_{\mathrm{b}} \times \mathrm{t}}}{\mathrm{C}_{\mathrm{s}} \times \mathrm{t}} \times \mathrm{A}_{\mathrm{s}}=0.5 \mathrm{nCi}
$$

where: $C_{b}=$ background counting rate (counts/second),

$\mathrm{t}=$ counting interval (seconds),

$\mathrm{C}_{\mathbf{S}}=$ counting rate of standard (counts/second), and

$\mathrm{A}_{\mathrm{S}}=$ activity of standard ( $\mathrm{nCi}$ ).

The corresponding limit for flux density detection using a 24-hour collection interval is $0.025 \pm 0.013 \mathrm{pCi} / \mathrm{m}^{2} \cdot \mathrm{s}$. 


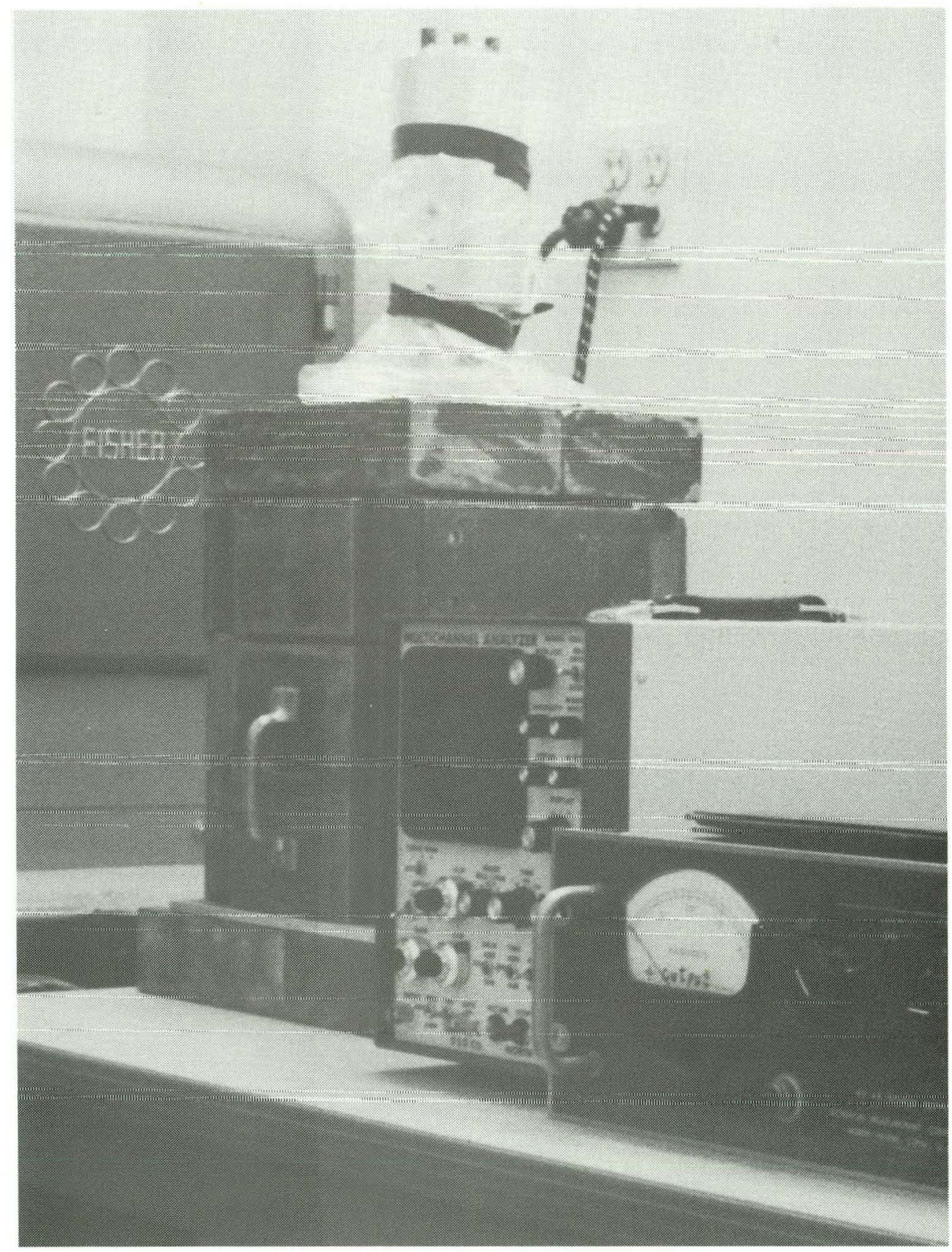

Figure 18. Canister Counting System. 


\section{FIELD MEASUREMENT OF RADON FLUX}

\section{NORMALIZATION OF RADON FLUX FIELD MEASUREMENTS}

Since atmospheric conditions cause changes in radon release rates, a reference location was established at an easily accessible location in the inactive open pit. Radon was collected each day from 1 March through $12 \mathrm{July}$, except for short interruptions in June. The radon activity in the canisters was measured after 24-hour collection intervals on weekdays and 48or 72-hour intervals over weekends. The flux at the reference location varied from 0.44 to $10.6 \mathrm{pCi} / \mathrm{m}^{2} \cdot \mathrm{s}$; the mean and standard deviation for 122 measurements was $1.9 \pm 1.5 \mathrm{pCi} / \mathrm{m}^{2} \cdot \mathrm{s}$. Figure 19 shows the temporal correlation between radon flux and barometric pressure. A $1 \%$ decrease in barometric pressure is associated with a two-fold increase in radon flux. This significant effect of barometric pressure is responsible for the large standard deviation in the average daily flux. An increase in flux of 20 to $60 \%$ for a change in barometric pressure of 1 to $2 \%$ has been previously reported (Clements and Wilkening 1974).

A comparison of radon flux measured at the reference location and the background site (SA-1) is shown in Figure 20. The mean and standard deviation of 56 measurements at Station SA-1 was $0.3 \pm 0.2 \mathrm{pCi} / \mathrm{m}^{2} \cdot \mathrm{s}$. A moving average of three successive values was used to smooth the data from each location. To plot these data on the same scale, the background values were multiplied by the ratio of the means of the data from each location. The plot shows that radon flux variations at the background location concur with the barometric pressure-induced changes observed at the reference location. The fact that other parameters affect radon flux is demonstrated by the difference in magnitude of the concurrent variations.

The data collected at the reference point were used as a control to adjust the short-term series of measurcments made at other locations for the time-related barometric pressure effect. The procedure used for normalizing short-term flux measurements to a 5-month average is as follows:

$$
\Phi_{g}=\Phi_{g \Delta t} \times \frac{\Phi_{c}}{\Phi_{c \Delta t}}
$$

where: $\Phi_{\mathrm{c}}=$ the average flux density at the control location (c), measured over the total 5-month period;

$\Phi_{\mathrm{g} \Delta \mathrm{t}}=$ the flux density at a given location $(\mathrm{g})$, measured over a short interval $(\Delta t)$;

$\Phi_{c \Delta t}=$ the flux density at the control location (c), measured over the same short interval $(\Delta t)$;

$\frac{\Phi_{C}}{\Phi_{c \Delta t}}=$ the normalization factor $\left(\mathrm{N}_{\mathrm{f}}\right)$; and

$\Phi_{\mathrm{g}}=$ the normalized flux density for a given location. 


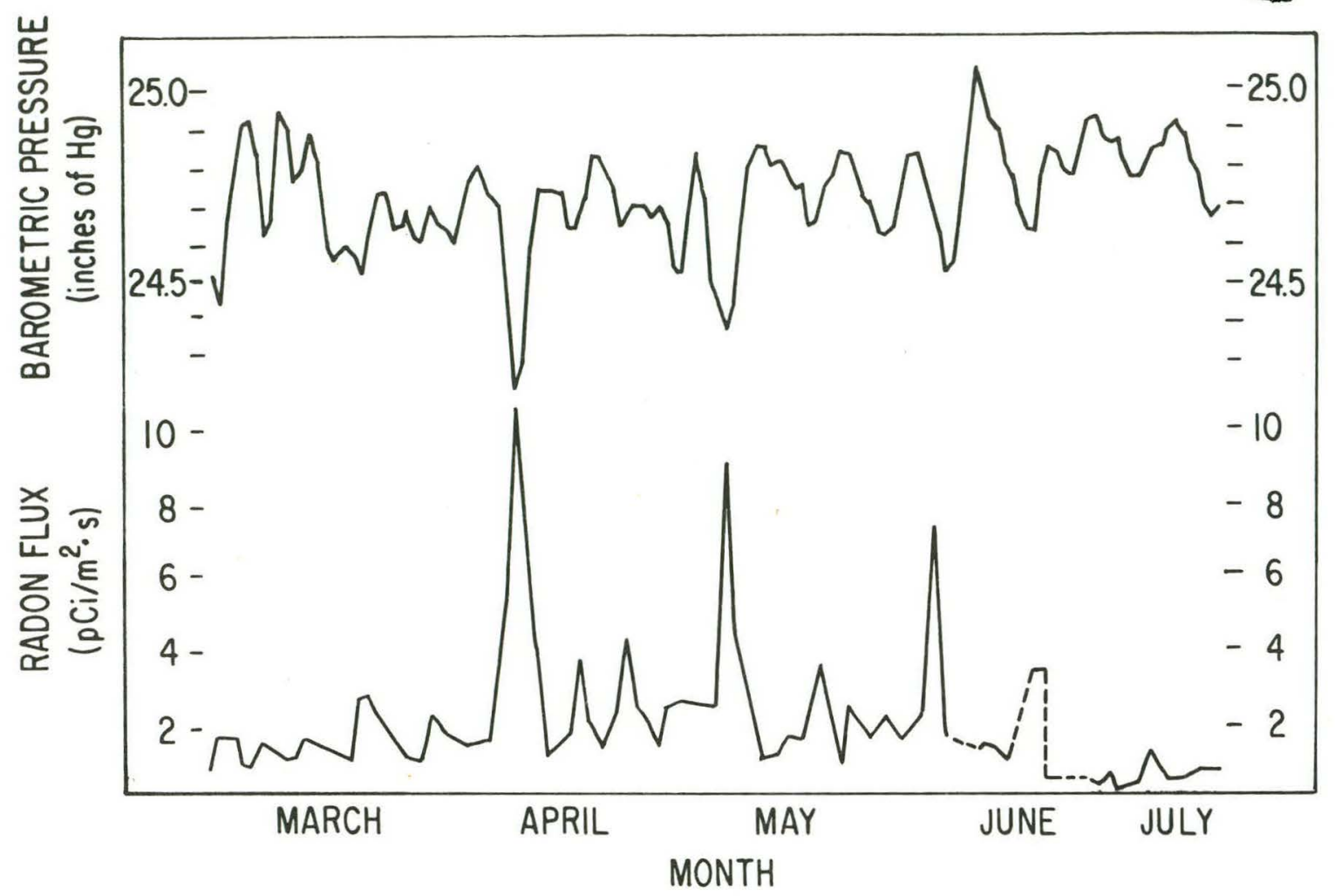

Figure 19. Comparison of Radon Flux with Barometric Pressure at the Inactive Pit, I March to 12 July 1979. Solid lines indicate average daily flux; dashed lines indicate interruptions.

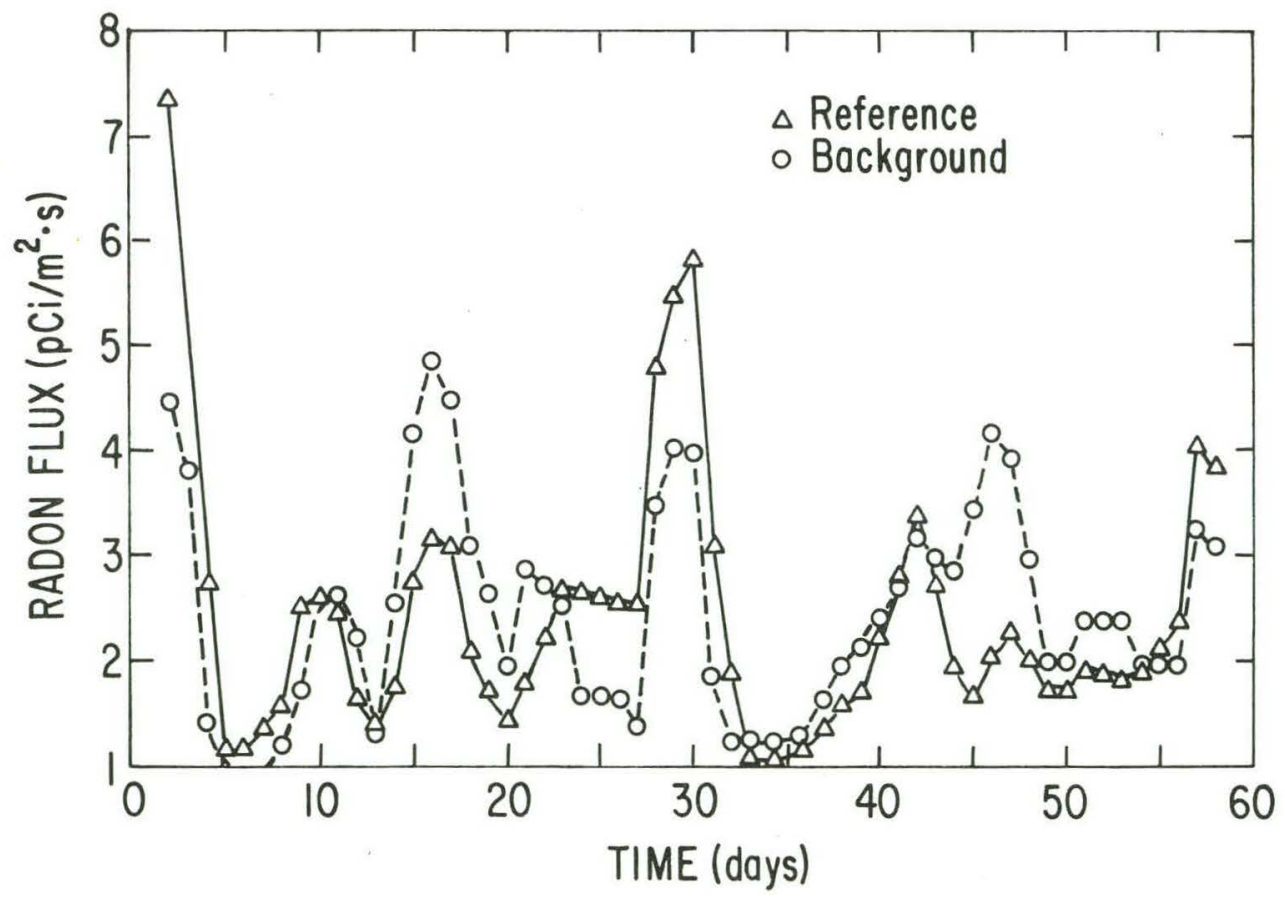

Figure 20. Comparison of Radon Flux at Reference and Background Locations. 
SURFACE AREA ESTIMATES AT THE ST. ANTHONY MINE

An enlargement of an aerial photograph taken by the Environmental Monitoring and Support Laboratory-Las Vegas (Figure 21) and a schematic representing the vertical cross section of the inactive mine (Figure 22) were used to describe the surface areas corresponding to the different levels of the pit. Level 1 represents the natural ground surface before excavation. Levels 2-6 represent sections in the developed open pit mine. A compensating polar planimeter was used to measure the areas of the outlined sections in Figure 21. These areas, multiplied by the appropriate scale factor, determined the horizontal surface areas of the corresponding mine shelves. The vertical surface area corresponding to the different levels was determined using the perimeter of the pit at each level and the estimated distance between adjacent shelves. Table 1 lists the estimated surface areas of the mine levels.

\section{RADON RELEASE FROM THE INACTIVE MINE}

Measurements of radon flux were made at 35 locations in the inactive pit. Radon was collected for 24-hour intervals using the previously described charcoal canister method. A summary of these measurements is presented in Table 2. The sequential flux measurements at each location were averaged and then normalized for variations in atmospheric conditions using the average flux at the reference point (see section on Normalization of Radon Flux Field Measurements). The normalized flux values for each section were averaged to obtain the radon release rate for that level. Level 1 represents background measurements made over undisturbed topsoil. The flux values for the different mine levels (2-6) range from $0.03 \mathrm{pCi} \mathrm{Rn}-222 / \mathrm{m}^{2} \cdot \mathrm{s}$ at Level 2 to $7.3 \mathrm{pCi}$ $\mathrm{Rn}-222 / \mathrm{m}^{2} \cdot \mathrm{s}$ at Leve1 5 , the ore zone. The highest average flux measured was $35.97 \mathrm{pCi} \mathrm{Rn}-222 / \mathrm{m}^{2} \cdot \mathrm{s}$ at Location 4, Leve1 5 .

The radon release rate from each section of the mine was determined by multiplying the surface area of that section (Table 1 ) by its average radon flux (Table 2). The flux values for the vertical surfaces were calculated from the average flux of the adjacent horizontal levels. The calculated release rates are presented in Table 3. The total release rate for the inactive open pit mine was $3.5 \times 10^{5} \mathrm{pCi} \mathrm{Rn}-222 / \mathrm{s}$. The relative contributions to this release rate are $6.6 \%$ from overburden and $93.4 \%$ from the ore zone. If it is assumed that the average release rate measured over this 5-month period represents an average for the entire year, then the annual radon release from the inactive pit would be $11 \mathrm{Ci} / \mathrm{yr}$. In comparison, the annual release from undisturbed topsoil (Level 1 ) with an area equal to the horizontal surface area of the mine would be $0.54 \mathrm{Ci} / \mathrm{yr}$.

The radon flux values for 16 random locations in the ore zone are listed in order of decreasing magnitude in Table 4. These flux values can be subdivided into two distinct ranges: 36 to $4.8 \mathrm{pCi} \mathrm{Rn}-222 / \mathrm{m}^{2} \cdot \mathrm{s}$ from ore; 2.5 to $0.4 \mathrm{pCi} \mathrm{Rn}-222 / \mathrm{m}^{2}$. s from subore. The estimated average flux from ore in the inactive pit at St. Anthony was $14.18 \mathrm{pCi} \mathrm{Rn}-222 / \mathrm{m}^{2} \cdot \mathrm{s}$, whereas that for subore was $1.69 \mathrm{pCi} \mathrm{Rn}-222 / \mathrm{m}^{2}$.s. If the flux from these individual locations is representative of the entire ore zone, then the fraction of the total observations relative to quality ore will be 0.25 . This assumption is 


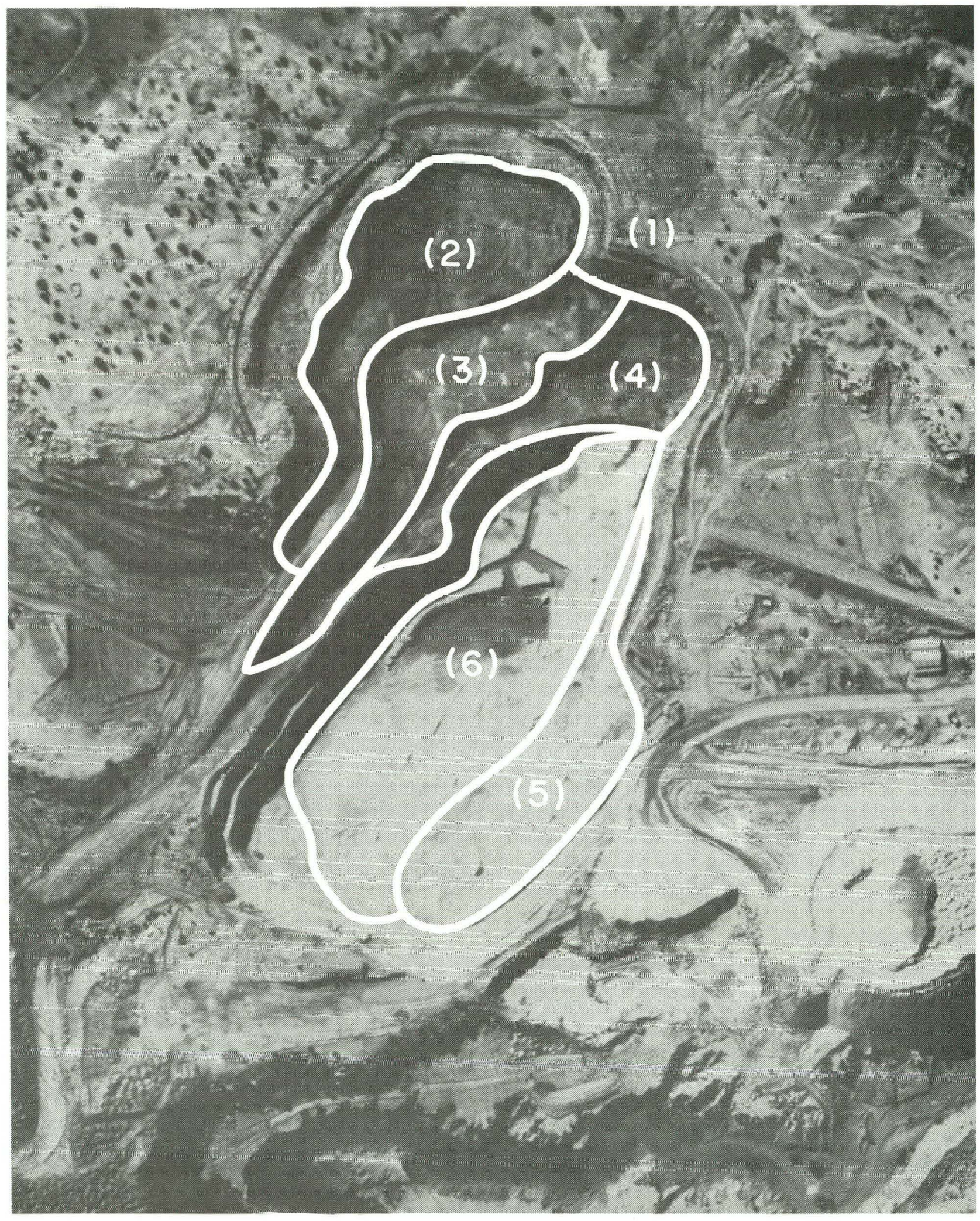

Figure 21. Enlarged Aerial View of the Inactive Pit Showing the Different Levels. 


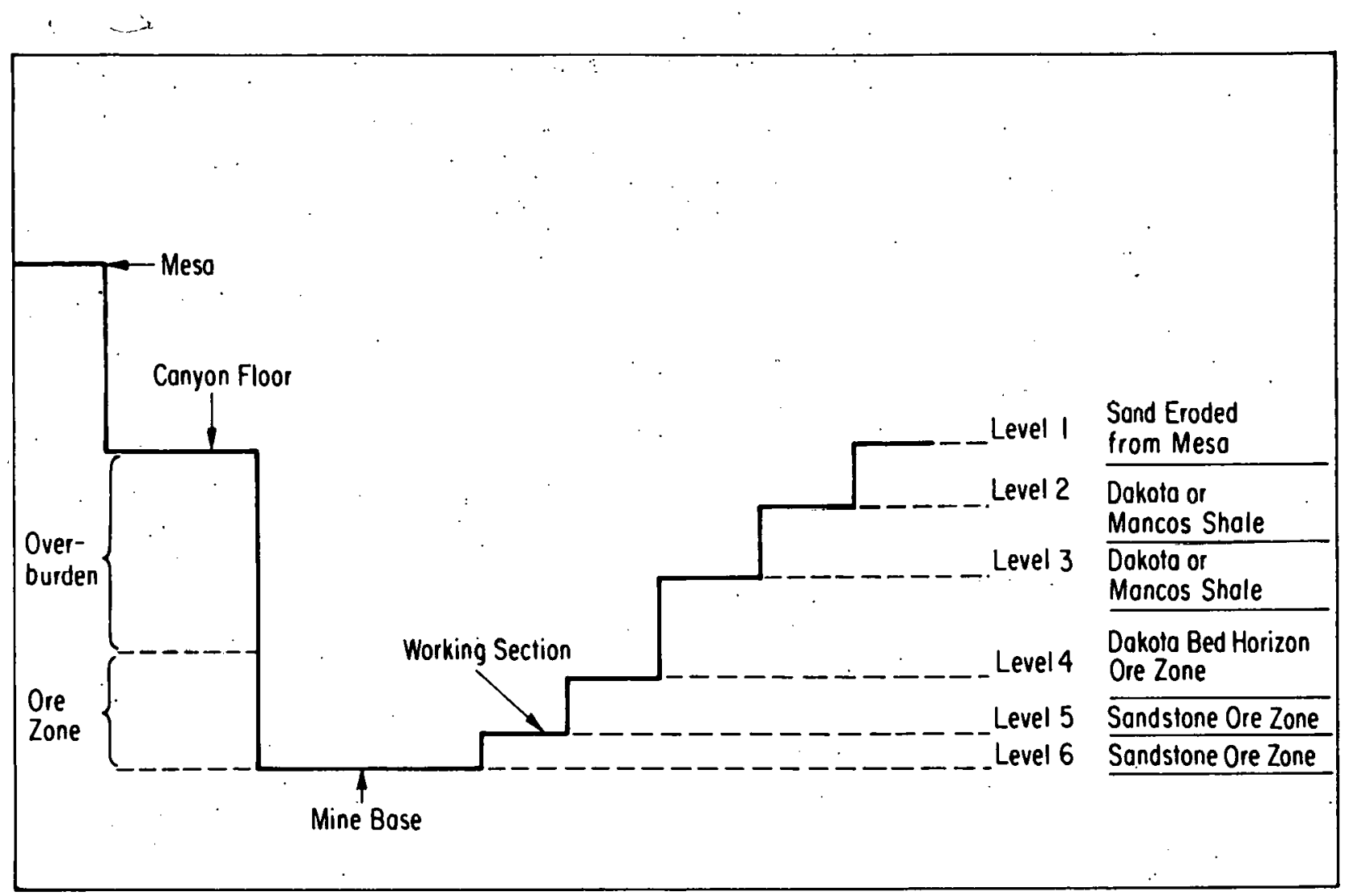

Figure 22. Schematic Vertical Cross Section of the Inactive Pit.

Table 1. Estimated Surface Areas of Inactive Open Pit Mine Areas

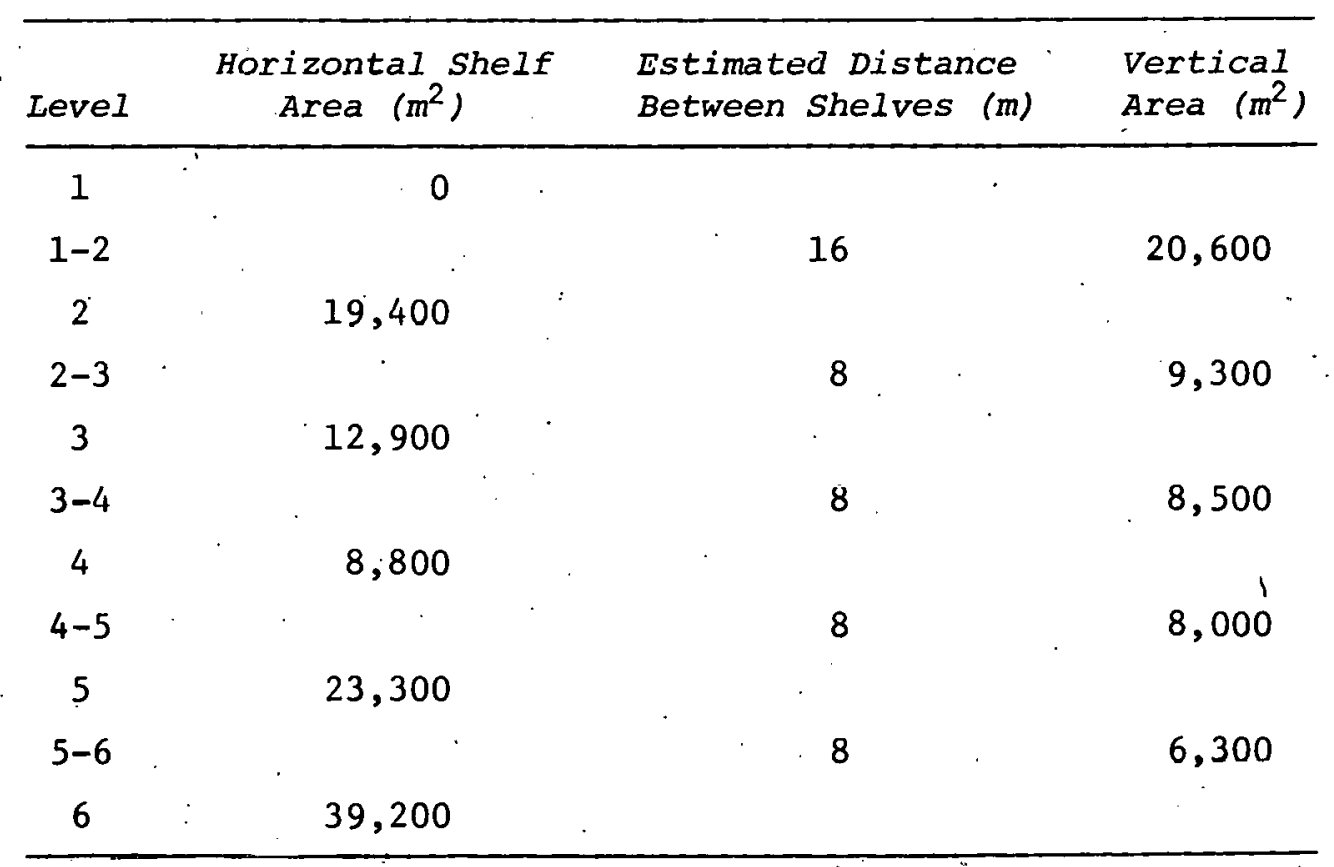


Table 2. Radon Flux Measured at Levels in the Inactive Open Pit

\begin{tabular}{|c|c|c|c|c|c|c|c|}
\hline Level & Description & Location & $\begin{array}{l}\text { Measurements } \\
\text { per Location }\end{array}$ & $\begin{array}{l}\text { Average Flux } \\
\text { per Location } \\
\left(\text { pCi/m } m^{2} \cdot s\right)\end{array}$ & $\begin{array}{l}\text { Normalization } \\
\text { Factor }\left(N_{f}\right)\end{array}$ & $\begin{array}{c}\text { Normalized } \\
\text { Flux } \\
\left(p C i / m^{2} \cdot s\right)\end{array}$ & $\begin{array}{c}\text { Average Flux } \\
\text { per Level } \\
\left(p C i / m^{2} \cdot s\right)\end{array}$ \\
\hline \multirow[t]{4}{*}{1} & \multirow{4}{*}{$\begin{array}{l}\text { Sand eroded } \\
\text { from mesas }\end{array}$} & 1 & 7 & 0.17 & 0.729 & 0.12 & \\
\hline & & 2 & 7 & 0.17 & 0.729 & 0.13. & \\
\hline & & 3 & 56 & 0.29 & 0.737 & 0.22 & \\
\hline & & 4 & 10 & 0.19 & 0.996 & 0.19 & 0.165 \\
\hline \multirow[t]{5}{*}{2} & \multirow{5}{*}{$\begin{array}{l}\text { Dakota or } \\
\text { Mancos Shale }\end{array}$} & 1 & 12 & 0.045 & 0.934 & 0.042 & \\
\hline & & 2 & 12 & 0.016 & 0.934 & 0.015 & \\
\hline & & 3 & 12 & 0.028 & 0.934 & 0.026 & \\
\hline & & 4 & 12 & 0.026 & 0.934 & 0.024 & \\
\hline & & .5 & 12 & 0.027 & 0.934 & 0.016 & 0.025 \\
\hline \multirow[t]{5}{*}{3} & \multirow{5}{*}{$\begin{array}{l}\text { Dakota or } \\
\text { Mancos Shale }\end{array}$} & 1 & 9 & 0.096 & 0.628 & 0.060 & \\
\hline & & 2 & 9 & 0.057 & 0.628 & 0.036 & \\
\hline & & 3 & 9 & 0.024 & 0.628 & 0.015 & \\
\hline & & 4 & 9 & 0.210 & 0.628 & 0.132 & \\
\hline & & 5 & 9 & 0.107 & 0.628 & 0.067 & 0.062 \\
\hline \multirow[t]{5}{*}{4} & \multirow{5}{*}{$\begin{array}{l}\text { Dakota bed, } \\
\text { Horizon ore } \\
\text { zone }\end{array}$} & 1 & 11 & 2.70 & 1.114 & 3.01 & \\
\hline & & 2 & 11 & 0.55 & 1.114 & 0.61 & \\
\hline & & 3 & 11 & 0.42 & 1.114 & 0.47 & \\
\hline & & 4 & 11 & 0.58 & 1.114 & 0.65 & \\
\hline & & 5 & 11 & 2.36 & 1.114 & 2.62 & 1.470 \\
\hline \multirow[t]{8}{*}{5} & \multirow{8}{*}{$\begin{array}{l}\text { Sandstone } \\
\text { ore zone }\end{array}$} & $1^{a}$ & 122 & 1.90 & (1) & 1.90 & \\
\hline & & 2 & 30 & 9.18 & 0.765 & 7.02 & \\
\hline & & 3 & 14 & 12.83 & 0.696 & 8.93 & \\
\hline & & 4 & 30 & 47.00 & 0.765 & 35.97 & \\
\hline & & 5 & 30 & 2.53 & 0.765 & 1.93 & \\
\hline & & 6 & 14 & 2.31 & 0.696 & 1.61 & \\
\hline & & 7 & 16 & 1.02 & 0.838 & 0.85 & \\
\hline & & 8 & 16 & 0.49 & 0.838 & 0.41 & 7.327 \\
\hline \multirow[t]{8}{*}{6} & \multirow{8}{*}{$\begin{array}{l}\text { Sandstone } \\
\text { ore zone }\end{array}$} & 1 & 22 & 1.29 & 1.274 & 1.64 & \\
\hline & & 2 & 12 & 0.96 & 1.405 & 1.35 & \\
\hline & & 3 & 12 & 0.86 & 1.405 & 1.26 & \\
\hline & & 4 & 22 & 1.80 & 1.274 & 2.29 & \\
\hline & & 5 & 12 & 1.48 & 1.405 & 2.07 & \\
\hline & & 6 & 10 & 4.18 & 1.147 & 4.80 & \\
\hline & & 7 & 10 & 2.20 & 1.147 & 2.52 & \\
\hline & & 8 & 10 & 2.14 & 1.147 & 2.46 & 2.299 \\
\hline
\end{tabular}

acontrol. 
Table 3. Radon Release Rate by Leve1

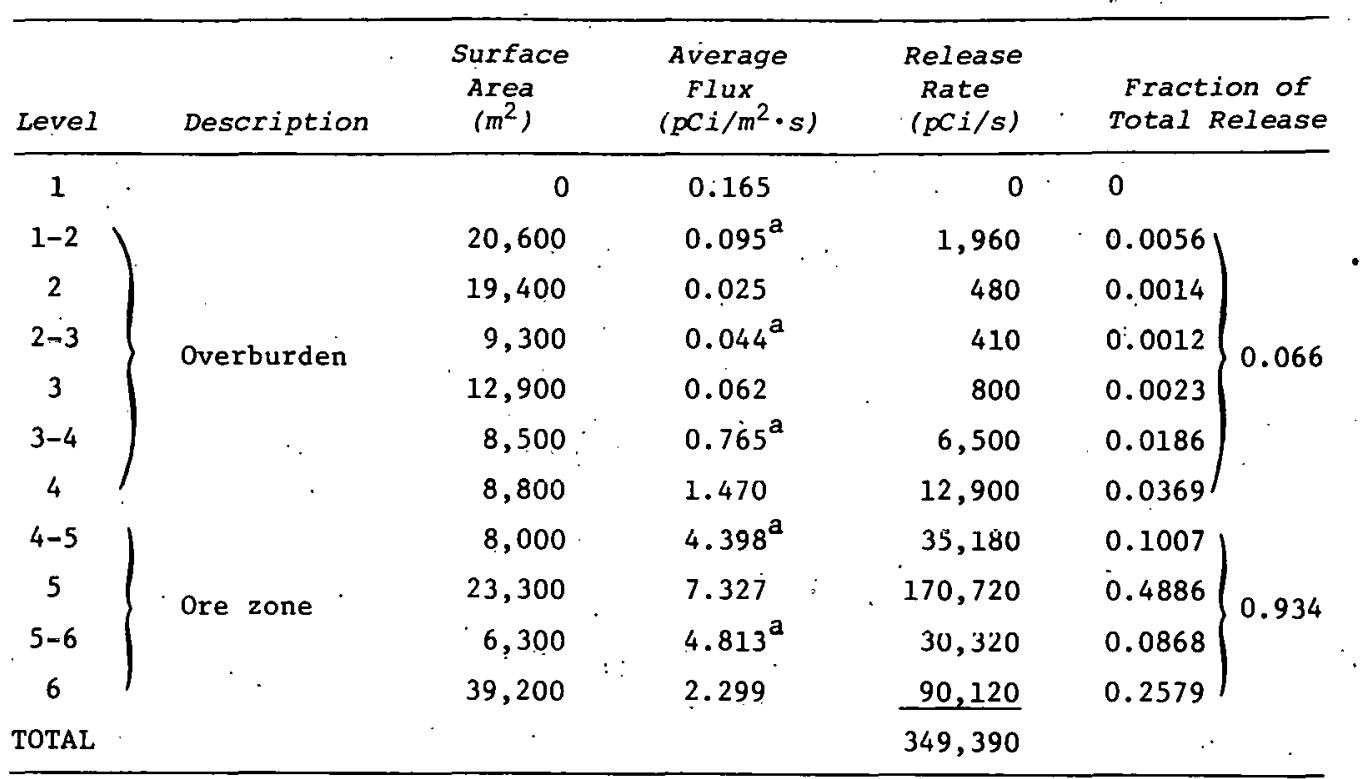

$a_{F l u x}$ was not measured on the vertical surfaces of the mine. These values were, determined by the average of the adjacent levcls.

Table 4. Ore Zone Flux in Order of Magnitude

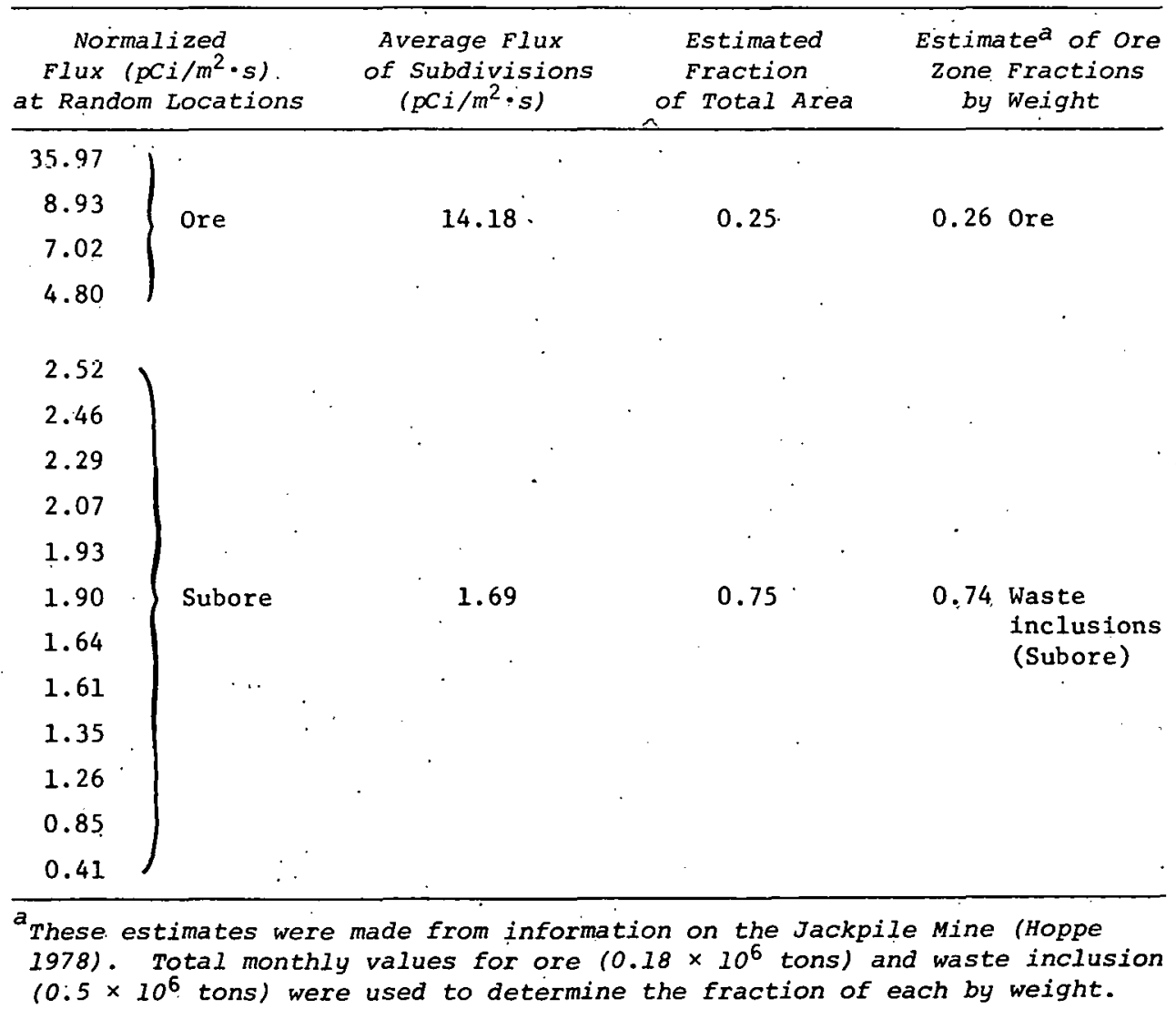


supported by information from the nearby Jackpile Mine operation (Hoppe 1978), which indicates that $26 \%$ of the material removed from the ore zone is quality ore and $74 \%$ is inclusive waste.

PROJECTION OF RADON RELEASE AS A FUNCTION OF MINE AGE

Increase in Surface Area as a Function of Mine Development

Since $93.4 \%$ of the radon from the open pit is released from the ore zone, the surface areas associated with this section of the mine are most important. The total horizontal area of the zone includes the working area $\left(S_{5}\right)$ and the mine base $\left(S_{6}\right)$ (Figure 22 ). The vertical surface of the ore zone is that area included between Levels 4 and 6 [ $\mathrm{S}_{4-6}$ ]. The following formulas (Equations 9-11) were used to determine the surface area of each section as a function of the volume of material removed from the ore zone.

The working area of the ore zone is composed of two equal sections alternately used for ripping and ore removal. The area of these sections can be determined from the volume of material removed per day and the ripping depth. Assuming the ore removal rate does not change, the surface area $\mathrm{S}_{5}$. will remain constant for the life of the mine.

$$
\mathrm{S}_{5}=2 \frac{\text { (Volume removed/day) }}{\text { (Ripping depth }} \times t
$$

where: $\dot{t}=1$ day.

The $S_{6}$ surface area, corresponding to the mine base, is the total horizontal area of the ore zone minus the working area; $\mathrm{S}_{6}$ will increase linearly with time and is directly related to the volume of material removed.

$$
\mathrm{S}_{6}=\left[\frac{(\text { Volume removed/year })}{\text { (Ore zone depth) }} \times \mathrm{T}\right]-\mathrm{S}_{5}
$$

where: $\mathrm{T}=$ mine age in years.

The vertical surface area of the ore zone wall included between Levels 4 and 6 is determined from the perimeter of the mine base (assuming a square geometry) and the depth of the ore zone.

$$
\mathrm{S}_{4-6}=\text { Ore zone depth } \times 4 \sqrt{\frac{\text { Volume removed/year }}{\text { Ore zone depth }}} \times \mathrm{T}
$$

The estimated parameters used for converting the ore production rate to volume. removed from the ore zone per day are given in Table 5. United Nuclear personnel (Abbiss and Savignac 1980--personal communication) viewed these parameters as reasonable estimates for the St. Anthony Mine. This calculation was done as follows:

$$
\begin{aligned}
V_{d}(\text { Volume removed } / \text { day }) & =\frac{r \text { (tons } / \text { day })}{f} \times \frac{0.9072 \text { metric tons } / \text { ton }}{\rho\left(\text { metric tons } / \mathrm{m}^{3}\right)} \\
& =3820 \mathrm{~m}^{3} / \text { day }
\end{aligned}
$$


Table 5. Parameters Used to Convert Ore Production Rate to Volume

\begin{tabular}{lcl}
\hline Parameter & Symbol & Volume \\
\hline $\begin{array}{l}\text { Ore production rate } \\
\text { Ore }\end{array}$ & $\mathrm{r}$ & 2000 tons/day \\
$\begin{array}{l}\text { (Ore + Subore + Waste inclusion) } \\
\text { Ore zone depth }\end{array}$ & $\mathrm{f}$ & 0.25 \\
Ripping depth & $16 \mathrm{~m}$ \\
Mine working days per year & $0.5 \mathrm{~m}$ \\
Ore density & 0 & $1.9 \frac{\text { tons (metric) }^{3}}{\mathrm{~m}^{3}}$
\end{tabular}

or

$$
\begin{aligned}
V_{y}(\text { Volume removed/year }) & =3820 \mathrm{~m}^{3} / \text { day } \times 285 \text { day } / \mathrm{yr} \\
& =1.09 \times 10^{6} \mathrm{~m}^{3} / \mathrm{yr}
\end{aligned}
$$

These rates, and the surface area formulas were used to determine the area projections presented in Figure 23.

\section{Projection of Radon Release Rates}

The projected surface areas and measured radon flux density values presented in Table 2 were used to determine the annual radon release for each section of the ore zone. The release rates given in Table 6 were calculated for yearly increments of mine age. The surface area $S_{5}$ and its corresponding radon flux density $\left(7.3 \mathrm{pCi} \mathrm{Rn}-222 / \mathrm{m}^{2} \cdot \mathrm{s}\right)$ yielded an annual release of $3.53 \mathrm{Ci} / \mathrm{yr}$. Since the area is constant and assuming that the ore quality and mining:rate do not change, this annual release remains constant for the life of the mine. However, the annual radon release for $S_{6}$ increases as the mine base surface area expands with continued mine development:. The average of the flux density values for Levels 4 and 6 was used to calculate the annual radon release from the vertical surface of the ore zone. The data in Table 6 indicate that this release increases gradually with mine age:

The relative contribution from each section of the ore zone to the total annual radon release as a function of both mine age and $\mathrm{U}_{3} \mathrm{O}_{8}$ production is shown in Figure 24. The annual radon releases'presented in Figure 24 represent $93.4 \%$ of the total release from the open pit. Radon release from dynamic processes such as ripping and removal has been considered, and an estimate $\left(10.04 \mathrm{Ci} / \mathrm{yr}\right.$ ) for an ore quality of $0.07 \% \mathrm{U}_{3} \mathrm{O}_{8}$ was obtained (see Appendix B): 


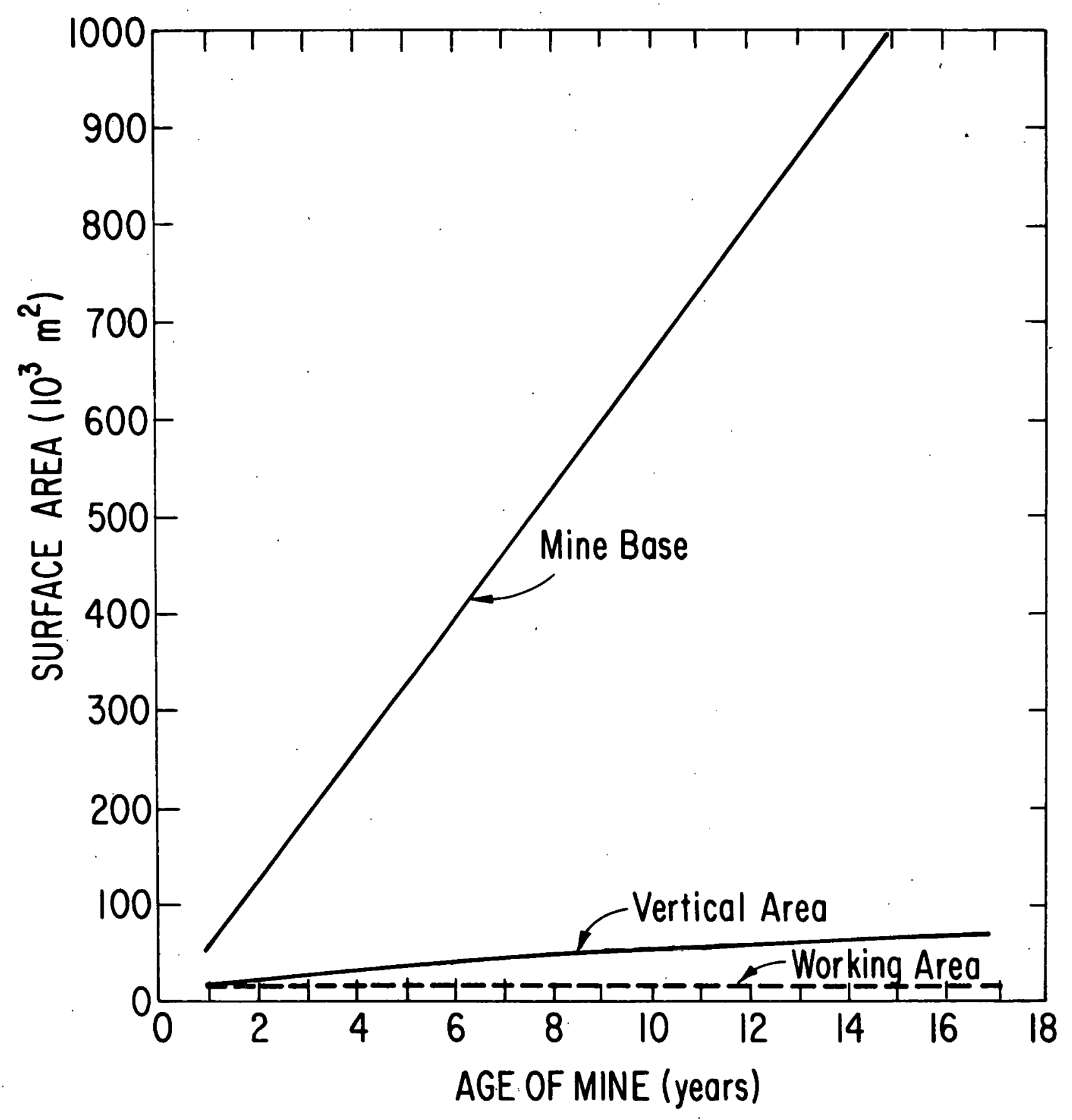

Figure 23. Projection of Ore Zone Surface Areas. 
Table 6. Projected Annual Radon Release

\begin{tabular}{ccccc}
\hline & \multicolumn{4}{c}{ Annual Release (Ci/yr) } \\
\cline { 2 - 5 } $\begin{array}{l}\text { Years of } \\
\text { Operation }\end{array}$ & Level 5 & Level 6 & Levels $4-6$ & $\begin{array}{c}\text { Total } \\
\text { Ore Zone }\end{array}$ \\
\hline 1 & 3.53 & 3.83 & 0.99 & 8.35 \\
2 & 3.53 & 8.78 & 1.40 & 13.71 \\
3 & 3.53 & 13.72 & 1.72 & 18.97 \\
4 & 3.53 & 18.66 & 1.99 & 24.18 \\
5 & 3.53 & 23.60 & 2.22 & 29.35 \\
6 & 3.53 & 28.55 & 2.43 & 34.51 \\
7 & 3.53 & 33.50 & 2.63 & 39.66 \\
8 & 3.53 & 38.48 & 2.81 & .44 .77 \\
9 & 3.53 & 43.37 & 2.98 & 49.88 \\
10 & 3.53 & 48.31 & 3.14 & 54.98 \\
11 & 3.53 & 53.26 & 3.29 & 60.08 \\
12 & 3.53 & 58.20 & 3.44 & 65.17 \\
13 & 3.53 & 63.14 & 3.58 & 70.25 \\
14 & 3.53 & 68.09 & 3.72 & .75 .34 \\
15 & 3.53 & 73.03 & 3.85 & 80.41 \\
16 & 3.53 & 77.97 & 3.97 & 85.47 \\
17 & 3.53 & 82.91 & 4.09 & 90.53 \\
\hline
\end{tabular}

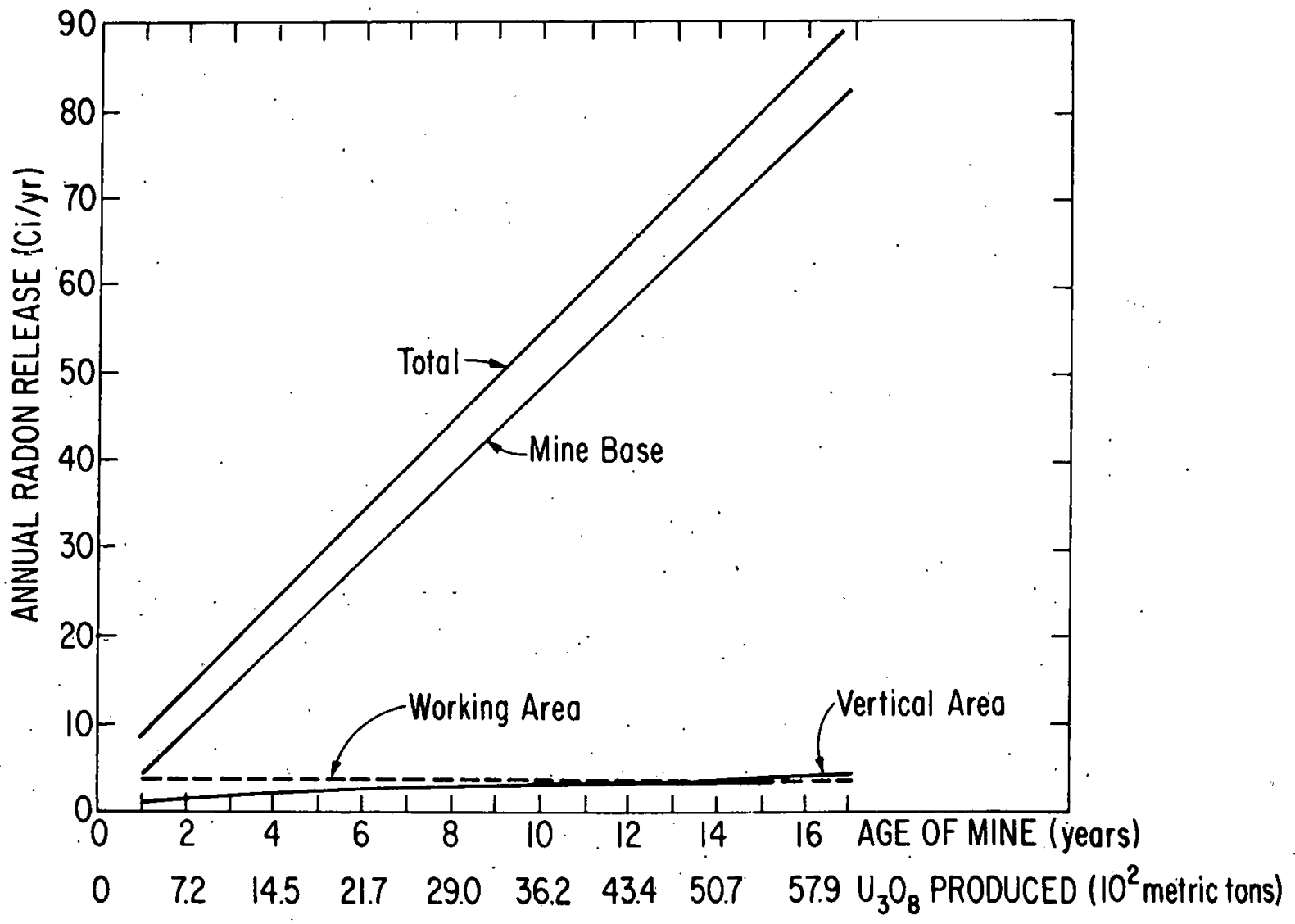

Figure 24. Projection of Radon Released from the Ore Zone. 
COMPARISON OF RADON FLUX WITH RADIUM-226 CONTENT OF ORE

In open pit mining, overburden is removed to reach the ore zone. The ore zone is then ripped to a depth of approximately 2 feet to facilitate ore removal. Mine personnel determine the approximate ore quality at several locations in the ripped area, and flags of different colors--each color corresponding to a specific ore quality range--are used to mark each location.

Radon flux was measured over these flagged locations using the methodology described in previous sections. Sixteen radon collectors were set out at the same time: three collectors at each of four different flagged locations, three in the adjacent unripped area, and one at the control location. Radon was collected for 24 hours and the radon flux density determined for each location (Table 7). These measurements were normalized to correct for the concurrent atmospheric conditions. The variation in flux values is indicative of radon release rates over deposits that have a nonuniform radium content.

Table 7. Radon Flux from Ripped Ore in the Active Open Pit

\begin{tabular}{|c|c|c|c|}
\hline Location & $\begin{array}{l}\text { Flux Density } \\
\left(p C i / m^{2} \cdot s\right)\end{array}$ & $\begin{array}{c}\text { Normalization } \\
\text { Factor }\left(N_{f}\right)\end{array}$ & $\begin{array}{l}\text { Corrected } \\
\text { Flux Density } \\
\left(p C i / m^{2} \cdot s\right)\end{array}$ \\
\hline \multirow[t]{3}{*}{ Red flag } & 1.8 & 1.416 & $2.55^{\mathrm{a}}$ \\
\hline & 2.6 & & 3.68 \\
\hline & 0.8 & & 1.13 \\
\hline \multirow[t]{3}{*}{ Yellow flag } & 0.2 & 1.416 & $0.28^{a}$ \\
\hline & 0.2 & & 0.28 \\
\hline & 0.1 & & 0.14 \\
\hline \multirow[t]{3}{*}{ White flag } & 0.8 & 1.416 & $1.13^{\mathrm{a}}$ \\
\hline & 1.4 & & 1.98 \\
\hline & 2.8 & & 3.96 \\
\hline \multirow[t]{3}{*}{ Blue flag } & 0.9 & 1.416 & $1.27^{\mathrm{a}}$ \\
\hline & 0.5 & & 0.71 \\
\hline & 1.8 & & 2.55 \\
\hline \multirow[t]{3}{*}{ Unripped area } & 1.3 & 1.416 & $1.84^{\mathrm{a}}$ \\
\hline & 0.3 & & 0.42 \\
\hline & 5.8 & & 8.21 \\
\hline
\end{tabular}

${ }^{a}$ Samples taken for Ra-226 analysis. 
Surface ore samples $(500 \mathrm{~g}$ ) were taken from under one of the three radon collectors located at each site. In the laboratory, the ore was dried at $80^{\circ} \mathrm{C}$ for 24 hours in an oven. Each sample was weighed before and after drying to determine the moisture content of the ore. Two 10-g (dry weight) fractions were taken from each sample. The radium was leached by heating the fractions in concentrated nitric acid for 48 hours. Following this, the solution was centrifuged to remove the undissolved material and diluted to $100 \mathrm{~mL}$. Ten milliliters of the radium leach solution was slowly evaporated to dryness. The residue was redissolved in $10 \mathrm{~mL}$ of $0.1 \mathrm{~N}$ nitric acid (to prevent damage to the radon bubbler from concentrated acid). This solution was then transferred to a radon bubbler and sealed. Radon was allowed to build up to $88.6 \%$ equilibrtum ( 12 days). The radon was de-emanated from the solution into an evacuated scintillation cell using nitrogen as the carrier gas. The radon de-emanation apparatus used is similar to that described and illustrated by Rushing et al. (1964) the American Public Health Association (1971), and Beckman (1975). Included in this system are a vacuum pump, mercury manometer, radon bubbler, scintillation cell, and counting equipment. The scintillation rate in the cells was measured with a 3-inch photomultiplier tube connected to a scaler. The activity of Ra-226 was calculated from the counting rate $\left(R_{S}\right)$ as follows:

$$
\operatorname{Ra}(p C i)=\frac{R_{s}-R_{b}}{R_{c}} \frac{1}{1-e^{-\lambda L_{1}}} \cdot \frac{1}{e^{-\lambda t_{2}}} \frac{\lambda t_{3}}{1-e^{-\lambda t_{3}}}
$$

where: $t_{1}=$ time interval allowed for growth of radon from radium (time between sealing and de-emanating bubbler) (days);

$t_{2}=$ time between sealing the cell and counting it (days);

$t_{3}=$ time interval of counting (days);

$\lambda=$ decay constant for $\mathrm{Rn}-222=0.181 \mathrm{~d}^{-1}$;

$\mathrm{R}_{\mathrm{S}}=$ observed count rate of sample (counts per minute [cpm]);

$\mathrm{R}_{\mathrm{b}}=$ background count rate $(\mathrm{cpm})$; and

$R_{c}=$ cell calibration factor (cpm/pCi $R n-222$ in equilibrium with daughters).

The percent moisture and $\mathrm{Ra}-226$ activity ( $\mathrm{pCi} / \mathrm{g}$ ) of the ore at each flagged location are presented in Table 8 . The moisture content of the ore varied from approximately 3 to $16 \%$. The $\mathrm{Ra}-226$ activity of the fractions analyzed ranged from 32.9 to $256.1 \mathrm{pCi} / \mathrm{g}$. The difference in activity between two fractions indicates a lack of homogeneity in the $500-g$ sample.

In Table 9, the Ra-226 concentrations are compared to the corresponding Rn-222. flux density values. The calculated specific flux, the ratio of flux. density ( $\mathrm{pCi} \mathrm{Rn}-222 / \mathrm{m}^{2} \cdot \mathrm{s}$ ) to $\mathrm{Ra}-226$ activity $(\mathrm{pCi} / \mathrm{g}$ ), varied from location to location. This ratin is affected by (1) spacial distribution of radium, (2) percent radon emanation, and (3) radon transport parameters, particularly moisture.

At the St. Anthony Mine, uranium ore is found in scattered stringers which are 6 to 18 inches deep (Anon. 1979). This irregularity in ore deposition results in nonuniform distribution of radium. 
Table 8. Radium-226 Assay of Ore from the Active Mine

\begin{tabular}{|c|c|c|c|}
\hline Location & $\%$ Moisture & $\begin{array}{l}\text { Ra-226 Activity } \\
(p C i / g d r y)\end{array}$ & $\begin{array}{c}\text { Average } \\
\text { Ra-226 Activity } \\
(p C i / g \text { dry })\end{array}$ \\
\hline \multirow[t]{2}{*}{ Red flag } & 15.8 & 256.1 & \\
\hline & & 198.8 & 227.5 \\
\hline \multirow[t]{2}{*}{ Yellow flag } & 14.3 & 60.5 & \\
\hline & & 79.5 & 70.0 \\
\hline \multirow[t]{2}{*}{ White flag } & 7.3 & 50.6 & \\
\hline & & 32.9 & 41.8 \\
\hline \multirow[t]{2}{*}{ Blue flag } & 3.4 & 38.9 & \\
\hline & & 53.8 & 46.4 \\
\hline \multirow[t]{2}{*}{ Unripped area } & 6.4 & 136.4 & \\
\hline & & 108.4 & 122.4 \\
\hline
\end{tabular}

Table 9. Comparison of Radon Flux with Radium-226 Concentration of Ore

\begin{tabular}{lccc}
\hline Location & $\begin{array}{c}\text { Radon Flux Density } \\
\left(p C i / m^{2} \cdot s\right)\end{array}$ & $\begin{array}{c}\text { Ra-226 ACtivity } \\
(p C i / g d r y)\end{array}$ & $\begin{array}{c}\text { Specific Flux } \\
\left(\frac{p C i R n-222 / m^{2} \cdot s}{p C i R a-226 / g}\right)\end{array}$ \\
\hline Red flag & 2.55 & 227.5 & 0.011 \\
Yellow flag & 0.28 & 70.0 & 0.004 \\
White flag & 1.13 & 41.8 & 0.027 \\
Blue flag & 1.27 & 46.4 & 0.027 \\
Unripped area & 1.84 & 122.4 & 0.015 \\
\hline
\end{tabular}


Laboratory studies have shown that variations in the percent emanation are large, even with ores from one locale. Austin (1975) reported a range of values for the effective emanating power of ore from different mines of 0.01 to 0.90. Many characteristics--including particle size, porosity, and mineral species--can affect the number of Rn-222 atoms that escape from the ore mineral grain. The theory for the emanating process has been outlined by Tanner (1964).

In light of the differences in measured moisture content of the ore (Table 8), its effect on radon transport should be considered. Tanner (1964) describes in detail the mechanisms controlling this effect.

The average of the specific flux values in Table 9 is 0.017 , with a range of 0.004 to $0.027\left(\mathrm{pCi} \mathrm{Rn}-222 / \mathrm{m}^{2} \cdot \mathrm{s}\right) /(\mathrm{pCi}$. Ra-226/g). This range demonstrates the effects caused by the conditions previously described. The average radon flux density for the 15 measurements $\left(2.01 \mathrm{pCi} / \mathrm{m}^{2} \cdot \mathrm{s}\right.$ [Table 7]) was less than the $7.33 \mathrm{pCi} / \mathrm{m}^{2} \cdot \mathrm{s}$ measured over the unripped working area in the inactive pit. This difference is probably due to the ripping procedure, which releases radon from the void space in the ore, thus reducing the subsequent radon flux. A more representative estimate of specific flux, 0.072 (pCi $\mathrm{Rn}-222 / \mathrm{m}^{2} \cdot \mathrm{s}$ )/(pCi Ra-226/g), was obtained using the average $\mathrm{Ra}-226$ content of the samples in Table 8 (102 pCi/g) and the average radon flux density measured at 8 locations over undisturbed ore $\left(7.33 \mathrm{pCi} / \mathrm{m}^{2} \cdot \mathrm{s}\right.$ [Table 2]).

Although the correlation between radium and radon appears obvious, the parameters affecting radon release vary to such a degree from location to location that estimates of radon flux density using theoretical methods based on diffusion phenomena and an average radium-226 concentration should be critically questioned. This is not to say that a theoretical method could not be devised. However, the data needed for a site-specific estimate would be more difficult to obtain than actual radon flux measurements.

\section{RADON AIR CONCENTRATION AND WORKING LEVEL}

Continuous measurements of working level and radon concentration in the air were made at Stations SA-1, SA-2 and SA-3 (see Figure 4) in the mine complex, and at Station SA-4 (background), located about $11 \mathrm{~km}$ north of the mine.

A description of the continuous radon and working level monitor (CRWM) (Figure 25) has been previously reported (Momeni et al. 1979). Air is drawn through a membrane filter at the rate of $30 \mathrm{~L} / \mathrm{min}$. The airborne radon daughters, Po-218 and Po-214, are collected on the filter, and their alpha activity is counted with a silicon-diffused junction detector. A fraction of this filtered air is directed through a scintillation cell, which is used to detect the alpha disintegrations from radon in the air. The response of the scintillation cells used in this system ranged from 3 to $5 \mathrm{cpm} / \mathrm{pCi} \mathrm{Rn} / \mathrm{L}$ and the background ranged from 1 to $4 \mathrm{cpm}$. The estimated lower limit of detection for the cells was $0.15 \pm 0.07 \mathrm{pCi} \mathrm{Rn} / \mathrm{L}$, or $150 \pm 70 \mathrm{pCi} \mathrm{Rn} / \mathrm{m}^{3}$.

The background for the silicon detector systems was less than 5 counts per hour and did not change significantly during the field studies. Efficiency 


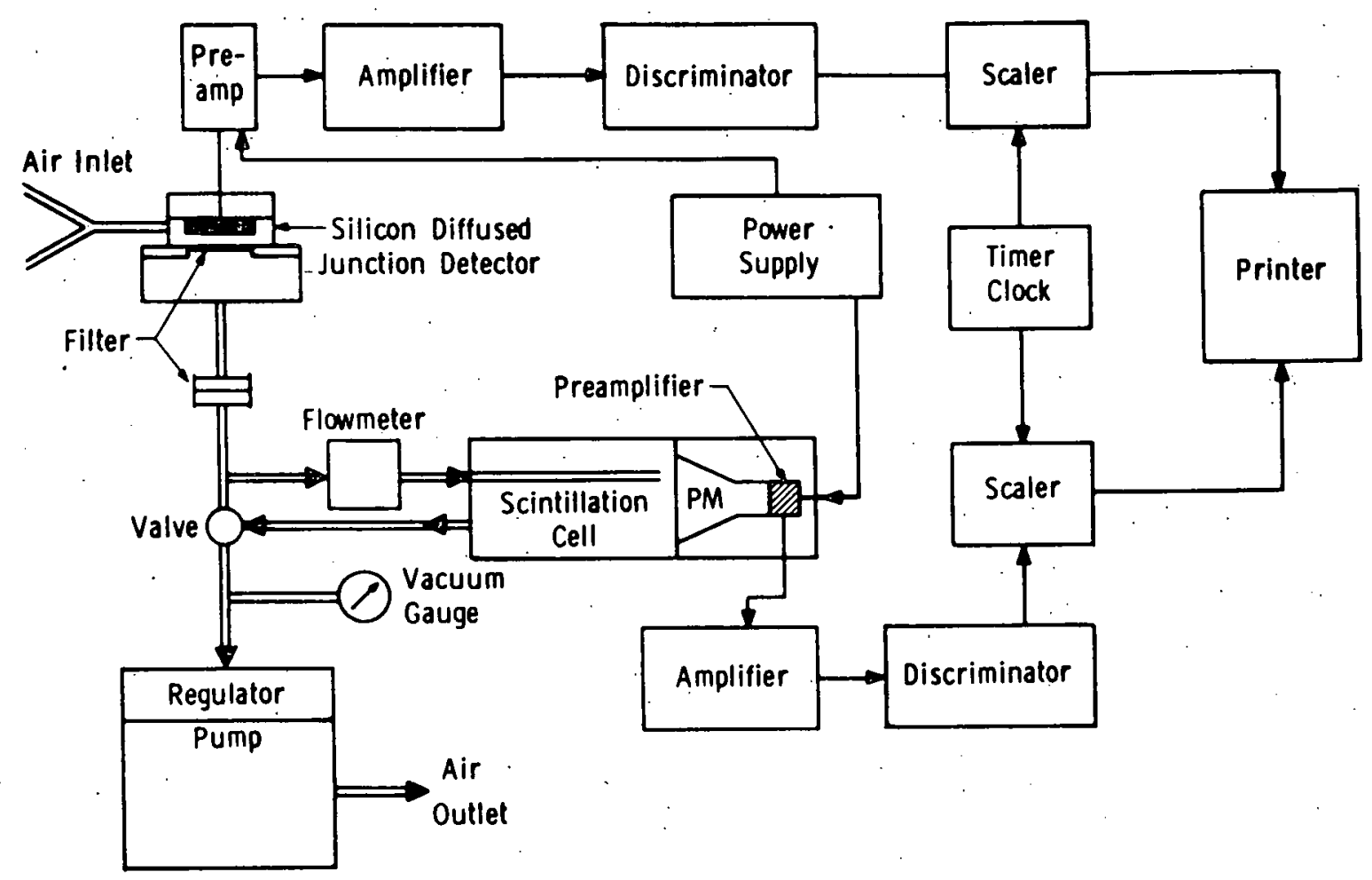

Figure 25. Continuous Radon and Working-Level Monitor.

estimates for these detectors ranged from 10 to $15 \%$, and the lower limit of detection was $1 \times 10^{-4} \pm 0.5 \times 10^{-4}$ working leve1 (WL), or $0.1 \pm 0.05 \mathrm{milli}$ working level (mWL).

\section{RADON CONCENTRATION IN AIR}

Typical hourly variations in the air concentration of radon measured at Station SA-1 on three different days are shown in Figure 26. Radon concentration is highest during the early morning hours and lowest during the middle afternoon. This phenomenon, previously observed by Momeni et al. (1979) was attributed to a thermal inversion. The complex radon concentration profile indicates four distinct peaks during 30 June 1979. A comparison of the data from Station SA-1 with that from the background Station SA-4 (Figure 26c) indicates that the radon air concentrations at these locations are nearly the same. This is also confirmed by the daily averages for SA-1 and SA-4.

Average monthly radon concentrations measured during June and July 1979 are given in Table 10. The means and standard deviations for Station SA-1 in June and July were $750 \pm 170 \mathrm{pCi} / \mathrm{m}^{3}$ and $1030 \pm 200 \mathrm{pCi} / \mathrm{m}^{3}$, respectively. At Station SA-3, located on a mesa $600 \mathrm{~m}$ due west of SA-1, the mean and standard deviation was $150 \pm 140 \mathrm{pCi} / \mathrm{m}^{3}$. Radon concentrations at the mesa station were about five times lower than those at the station in the valley. 

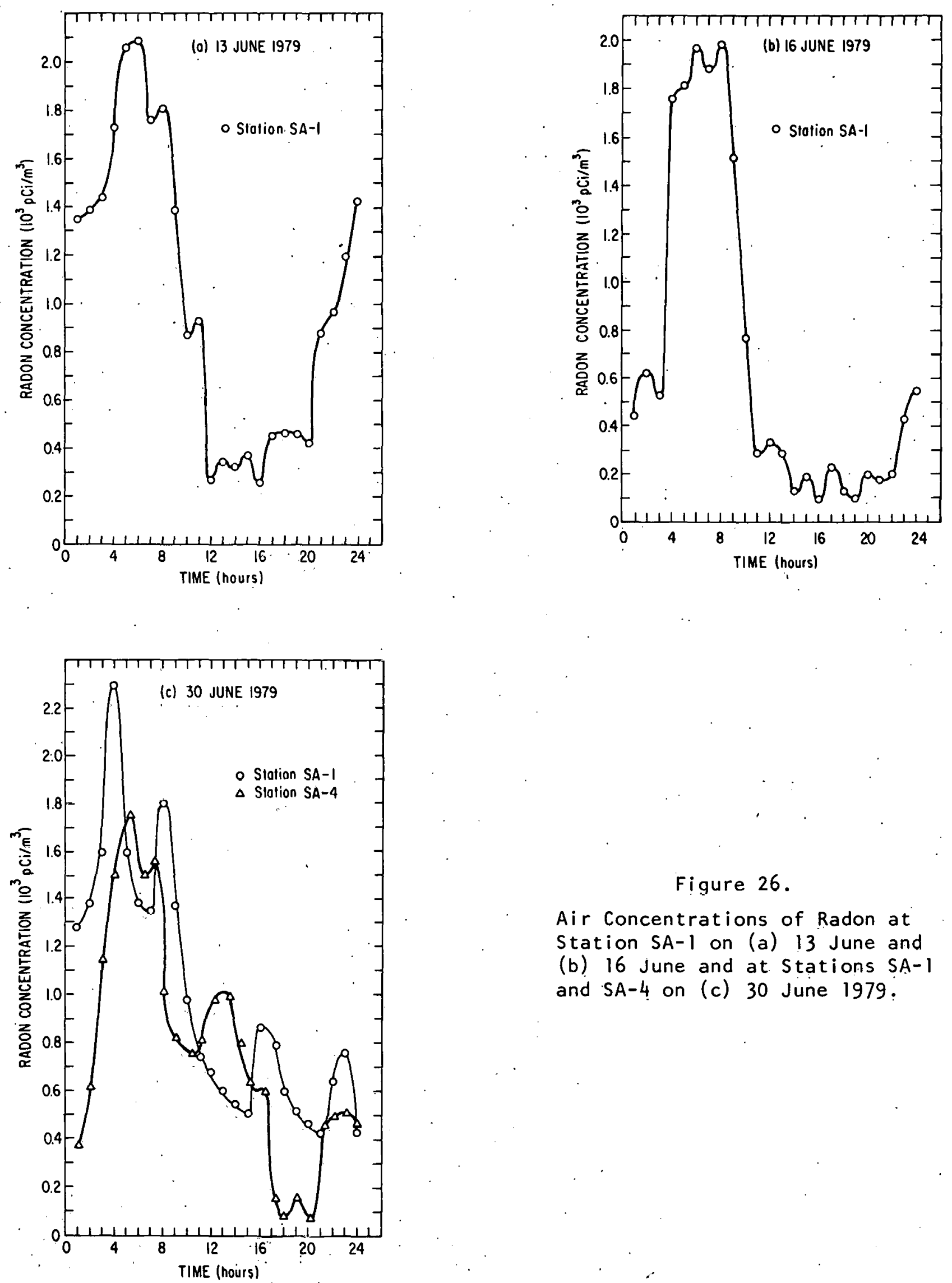

Figure 26.

Air Concentrations of Radon at Station SA-1 on (a) 13 June and (b) 16 June and at Stations SA-1 and SA-4 on (c) 30 June 1979: 
Table 10. Summary of Working Level and Radon Concentration Data at St. Anthony Mine ${ }^{a}$

\begin{tabular}{|c|c|c|c|c|c|c|c|}
\hline \multirow[b]{2}{*}{ Unit } & \multirow[b]{2}{*}{ Date ${ }^{b}$} & \multicolumn{3}{|c|}{ Working Level } & \multicolumn{3}{|c|}{ Radon Concentration $\left(\mathrm{CC} / \mathrm{m}^{3}\right)$} \\
\hline & & $\begin{array}{c}\text { Hourly } \\
\text { Measurements }\end{array}$ & Mean & $\begin{array}{l}\text { Est. } \\
\text { std. Dev. }\end{array}$ & $\begin{array}{c}\text { Hourly } \\
\text { Measurements }\end{array}$ & Mean & $\begin{array}{c}\text { Est. } \\
\text { std. Dev. }\end{array}$ \\
\hline \multicolumn{8}{|c|}{ Station SA-1 } \\
\hline CRWM 104 & Jun 79 & 491 & $9.182 \mathrm{E}-03$ & $1.877 \mathrm{E}-03$ & 491 & $7.478 \mathrm{E}+02$ & $1.678 \mathrm{E}+02$ \\
\hline CRWM 104 & Jul 79 & 275 & $1.023 \mathrm{E}-02$ & $2.193 \mathrm{E}-03$ & 275 & $1.034 \mathrm{E}+03$ & $2.005 E+02$ \\
\hline \multicolumn{8}{|c|}{ Station SA-2 } \\
\hline CRWM 103 & Jun 79 & 218 & $3.708 \mathrm{E}-03$ & $7.076 \mathrm{E}-04$ & 0 & 0 & 0 \\
\hline CRWM 103 & Jul 79 & 203 & $5.561 \mathrm{E}-03$ & $1.156 \mathrm{E}-03$ & 0 & 0 & 0 \\
\hline \multicolumn{8}{|c|}{ Station SA-3 } \\
\hline CRM 102 & Jun 79 & 0 & 0 & 0 & 161 & $1.491 \mathrm{E}+02$ & $1.439 \mathrm{E}+02$ \\
\hline \multicolumn{8}{|c|}{ Station SA-4 } \\
\hline CRWM 102 & Jun 79 & 415 & $1.231 \mathrm{E}-03$ & $2.318 \mathrm{E}-04$ & 415 & $8.808 \mathrm{E}+02$ & $2.007 E+02$ \\
\hline CRWM 102 & Ju1 79 & 382 & $1.290 \mathrm{E}-03$ & $2.350 \mathrm{E}-04$ & 382 & $9.745 \mathrm{E}+02$ & $2.108 E+02$ \\
\hline
\end{tabular}

\footnotetext{
Location of stations: SA-1, near the 10-m tower in the middle of the valley; SA-2, between active and inactive pits (about $10 \mathrm{~m}$ above the base of the valley on topsoil storage site); SA-3, on the mesa near the 33-m tower (about $100 \mathrm{~m}$ above the valley floor); $S A-4$ (background), at field laboratory trailer about $11 \mathrm{~km}$ north of the mine.

${ }^{b}$ Calibration date for all units was 6 June 1979.
}

(The data used to prepare this surmary are available as a supplement to. this document on request from Argonne National Laboratory.)

The means and standard deviations for the background Station SA-4 in June and July 1979 were $880 \pm 200 \mathrm{pCi} / \mathrm{m}^{3}$ and $975 \pm 210 \mathrm{pCi} / \mathrm{m}^{3}$, respectively. A comparison of the background data with that collected in the mine valley (SA-1) shows no significant differences in the air concentration of radon. It should be noted that these radon concentrations may include contributions from the Jackpile Mine and the Sohio Uranium Mill, which are near the St. Anthony Mine.

\section{WORKING LEVEL CONCENTRATION}

Hourly variations in working level and radon concentration at Station SA-1 during 14 June 1979 are shown in Figure 27. Although the fluctuations in radon concentration are more pronounced, the 24 -hour profiles seem relatively consistent. With few exceptions, this general relationship between radon concentration and working level was observed.

The means and standard deviations of working level measurements at the background station (SA-4) for June and July 1979 were $1.23 \pm 0.23 \mathrm{mWL}$ and $1.29 \pm 0.24 \mathrm{mWL}$, respectively (Table 10). At SA-1, the means and standard deviations for the same two months were $9.18 \pm 1.88 \mathrm{mWL}$ and $10.2 \pm 2.19 \mathrm{mWL}$ (Table 10), respectively. The measurements made at Station SA-2, which is located between the active and inactive pits, had means and standard deviations of $3.71 \pm 0.71 \mathrm{mWL}$ and $5.56 \pm 1.16 \cdot \mathrm{mWL}$ for these corresponding periods 


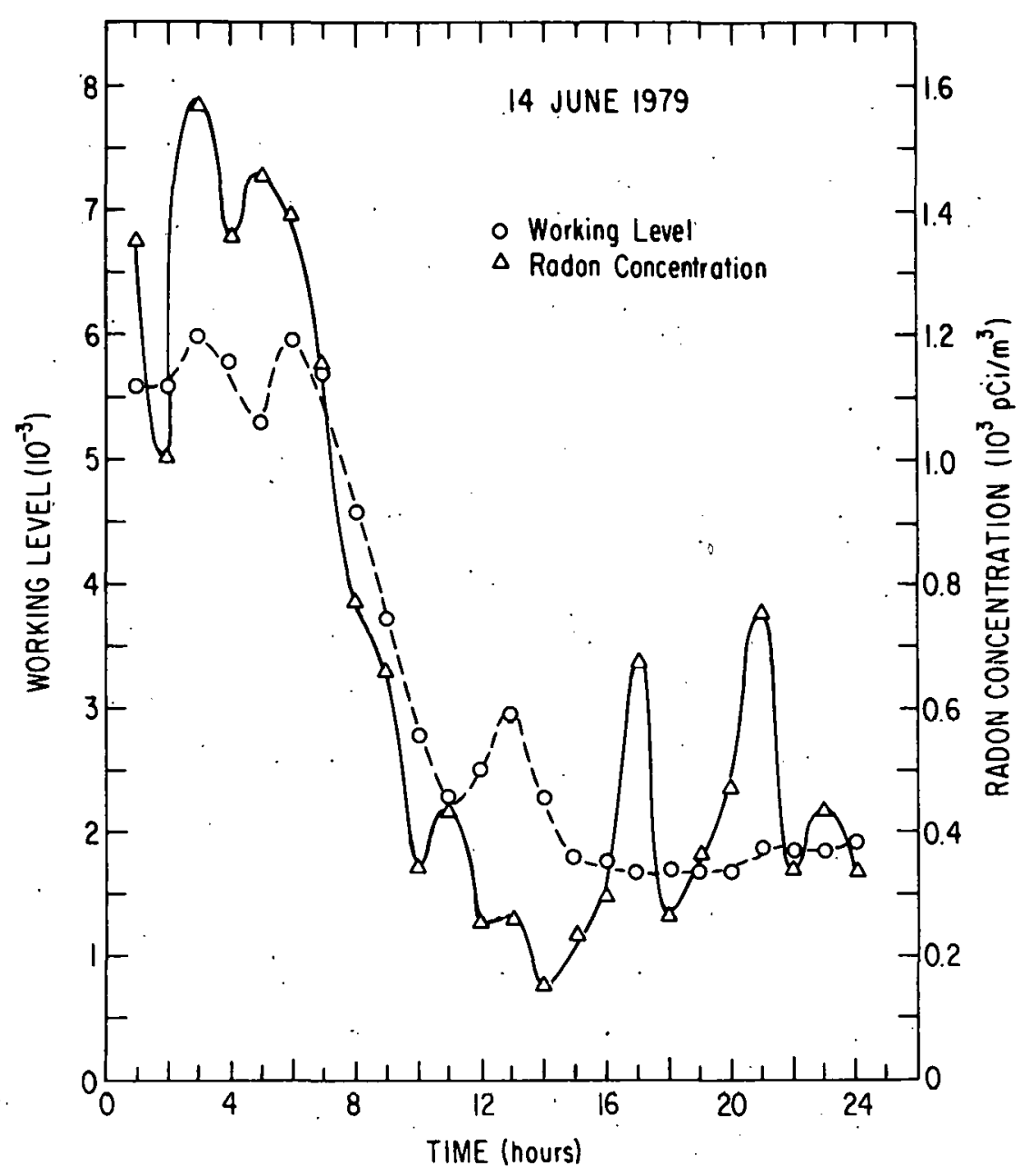

Figure 27. Comparison of Working Level and Radon Air Concentration at Station SA-I on 14 June 1979.

(Table 10). Working level averages at the mine show an elevated concentration when compared to the background averages. This conclusion, however, is not supported by corresponding radon concentrations at SA-1 and SA-4. Differences in topography should allow a higher buildup of radon-progeny in the mine canyon, but at this time any conclusion is only tentative.

\section{COMPARISON OF RADON GROUND FLUXं WITH RADON AIR CONCENTRATION}

The exhalation rate of radon from any ground surface is dependent on meteorological and climatic factors. The difficulty in understanding the effect of a single variable on the radon exhalation rate is due to the complex interrelationship between variables. The major portion of flux data has been obtained with radon collections of short duration. It is difficult to correlate the variations in these measurements with changes in atmospheric conditions. To facilitate a better comprehension of the observed variation in radon flux, a continuous radon flux monitor (CRFM) was constructed. 
The design of the CRFM* is shown schematically in Figure 28 and in photographs in Figure 29. The principle of measurement is based on the simultaneous determination of radon concentration in air before and after mixing with the radon exhaled from the surface area of the ground. Air is continuously pulled through the system at a height of $1.5 \mathrm{~m}$ above the ground using two mass-flow-regulated pumps, $P_{1}$ and $P_{2}$. Large particles are filtered from the inlet air using a stainless steel screen (S). The air flow is subdivided at junction $\mathrm{J}$, and one stream designated as "Air" is passed through a membrane filter $\left(F_{1}\right)$. The air, free from radon daughters, is then passed through a 2-liter aluminum scintillation cell $\left(C_{1}\right)$. During the passage of radon through the cell, it decays to Po-218 ions, which subsequently deposit on the scintillation surface due to their electrostatic charge. The alpha emission from Po-218, and subsequently from Po-214, results in scintillations within the cell, which then are detected by the phototube $\left(\mathrm{PM}_{1}\right)$.

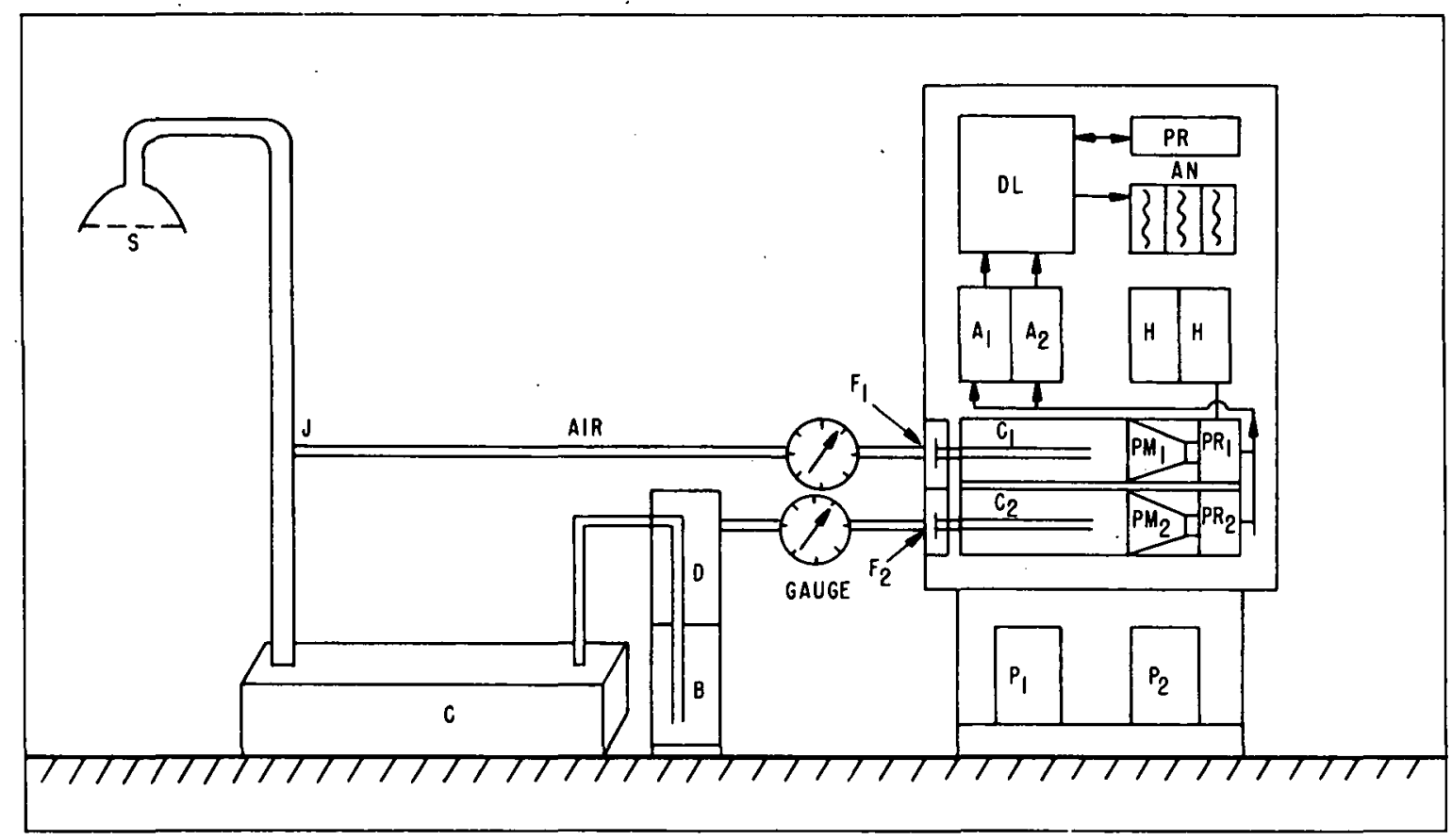

Figure 28. Schematic of Continuous Radon Flux Monitor.

The photomultiplier signal was amplified $\left(P R_{1}, A_{l}\right)$ and processed (DL) for both analog (AN) and digital (PR) readout. The operation of the system is programmed for preselected intervals of data integration.

The remaining air flow subdivided at junction $J$ passes through the radon collector (C). Radon released from the ground under the collector is mixed with this air which, in addition to the radon, carries moisture evaporated from the ground surface. The condensor (B) and drier (D) remove moisture before the air passes through the filter $\left(F_{2}\right)$ and cell $\left(C_{2}\right)$. The detection and readout system is similar to that described above.

*Patent application in progress. 

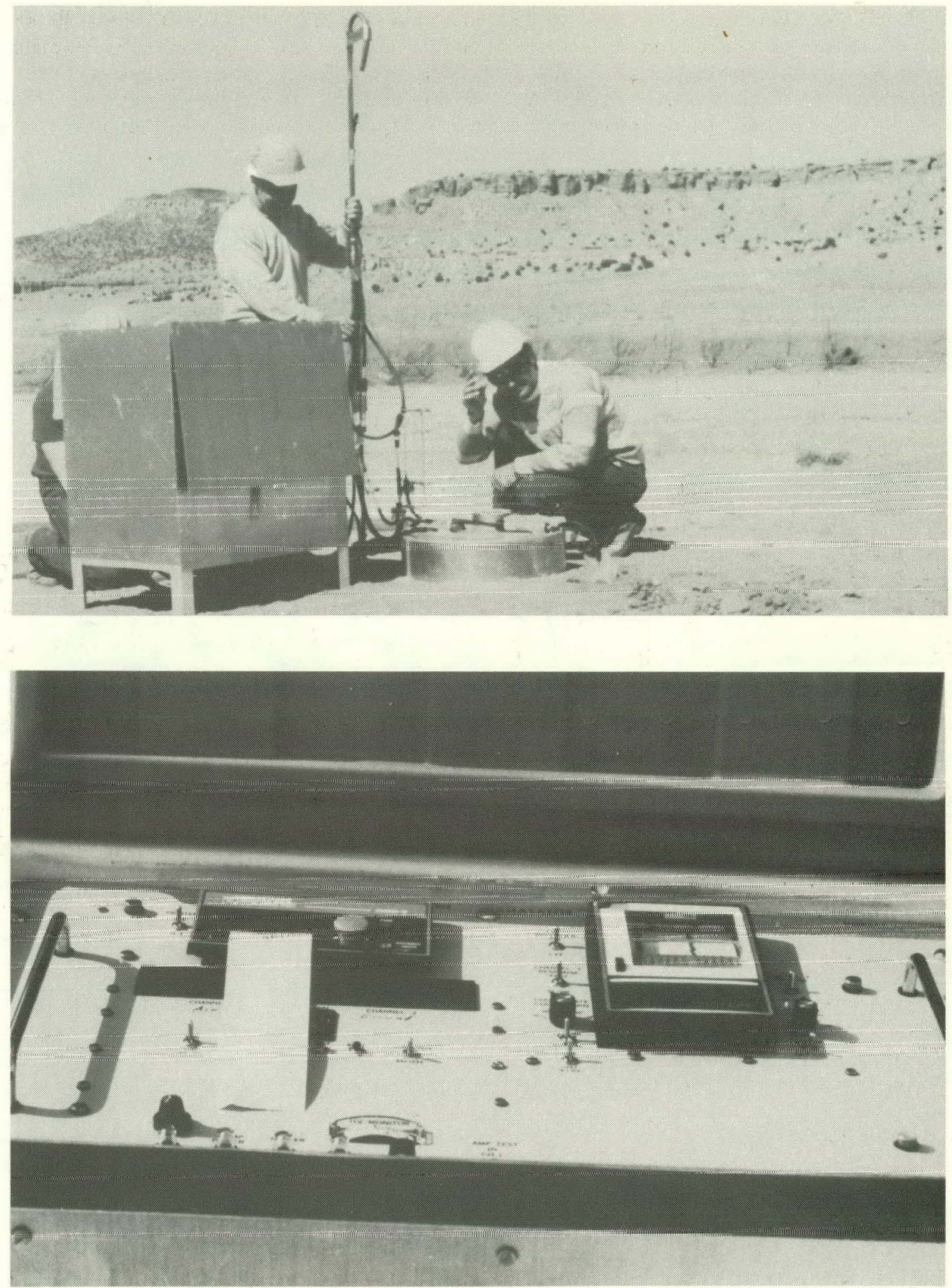

Figure 29. Photographs of Continuous Radon Flux Monitor. Top: instrument at field location; bottom: instrument panel. 
The CRFM was field-tested at the Anaconda Uranium Mill. Figure 30 shows radon flux and air concentration as a function of time. Radon flux varied from $8 \mathrm{pCi} \mathrm{Rn}-222 / \mathrm{m}^{2} \cdot \mathrm{s}$ to $38.5 \mathrm{pCi} \mathrm{Rn}-222 / \mathrm{m}^{2} \cdot \mathrm{s}$. This demonstrates a fivefold change in flux within an 85-hour measurement. Over short periods, the flux showed well-defined variations, which seemed to follow a diurnal cycle.

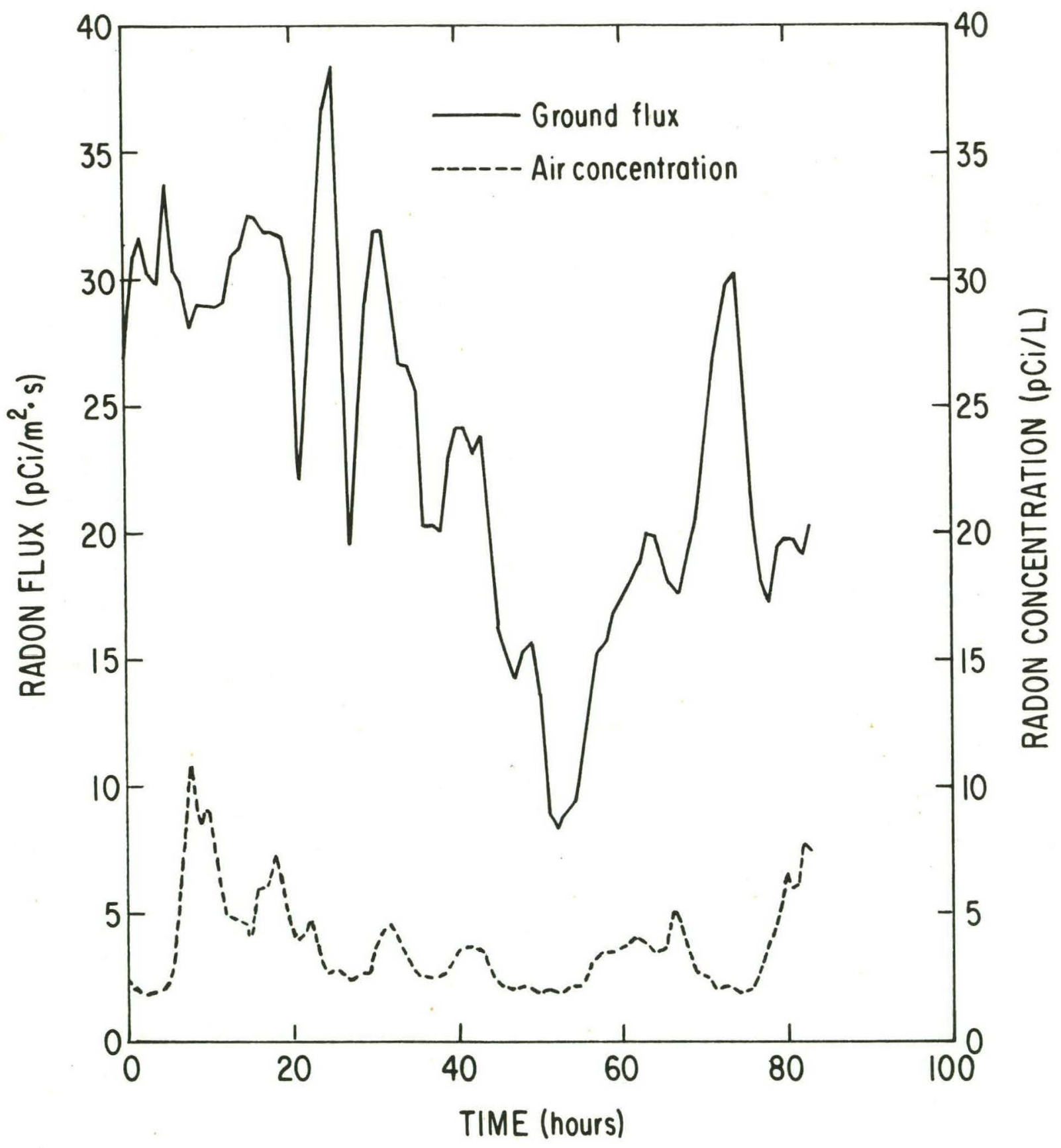

Figure 30. Concurrent Radon Air Concentration and Ground Flux at the Anaconda Uranium Mill. 
$\because$,

The plot of the radon flux and air concentration measurements made at St. Anthony Mine Station SA-I (Figure 31) shows a parallel rise and fall of ground exhalation and radon air concentration. Over this 24-hour period, the air concentration varied by approximately a factor of four, while ground flux varied by less than a factor of two. Preliminary data measured at Station SA-1 are given in Table 11 .

In open pit mining, explosives are used to loosen, overburden. This blasting process results in an instantaneous radon release from the open pit. This release was observed at Station SA-1, about $400 \mathrm{~m}$ away, as a temporary increase in radon air concentration. The radon ground flux was not significantly increased by the blasting (Table 11).

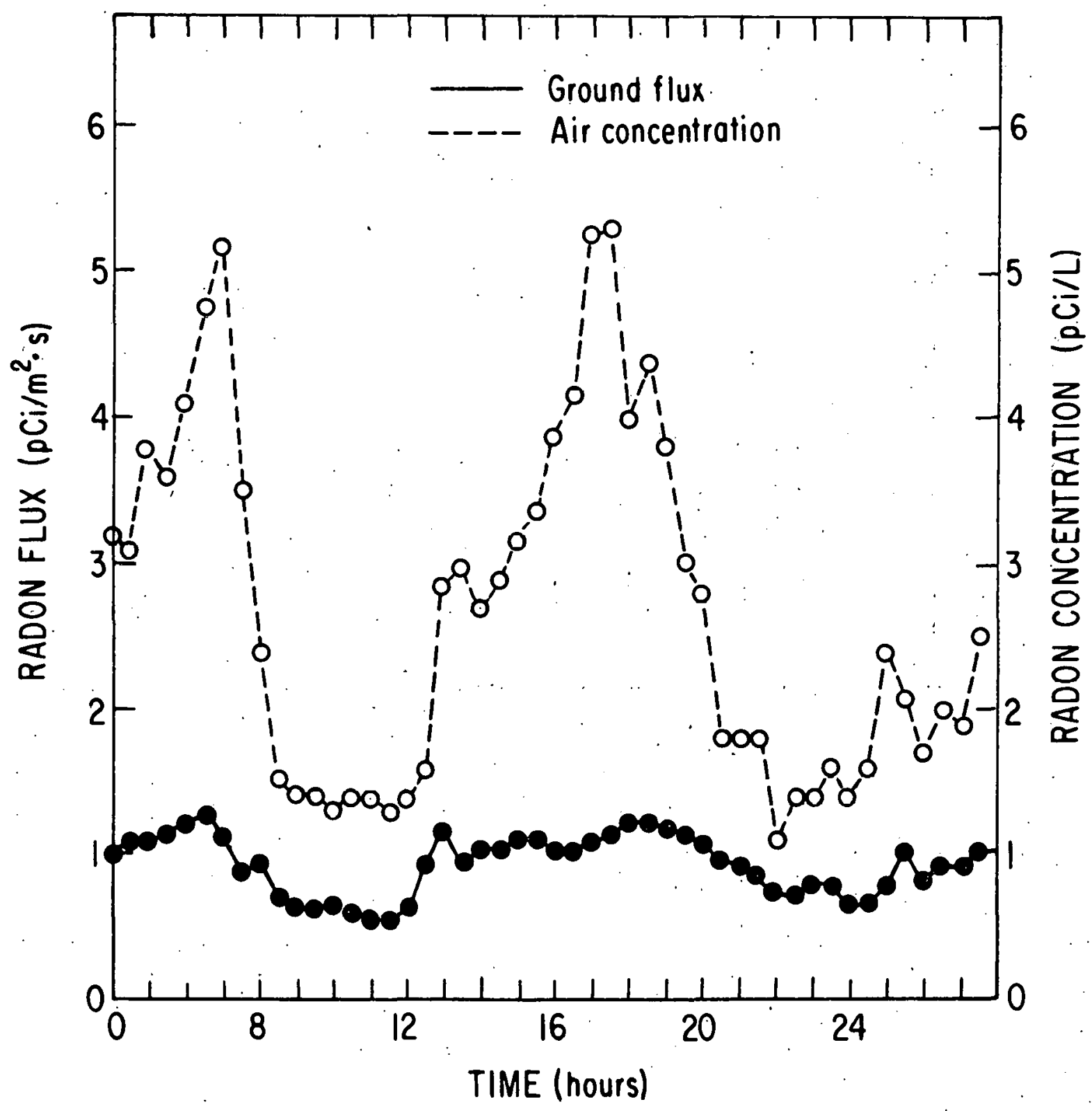

Figure 31. Concurrent Radon Air Concentration and Ground Flux at the St.. Anthony Mine. 
Table 11. Radon Air Concentration and Flux Measurements at St. Anthony Mine Station SA-1, April 1979

\begin{tabular}{|c|c|c|c|c|c|c|}
\hline \multirow[b]{2}{*}{$\begin{array}{l}\text { Time } \\
\text { (h) }\end{array}$} & \multicolumn{2}{|c|}{11 April } & \multicolumn{2}{|c|}{12 April } & \multicolumn{2}{|c|}{15 April } \\
\hline & $\begin{array}{c}\text { Radon } \\
\text { Concentration } \\
(p C i / L)\end{array}$ & $\begin{array}{l}\text { Radon Flux } \\
\left(p C i / m^{2} \cdot s\right)\end{array}$ & $\begin{array}{c}\text { Radon } \\
\text { Concentration } \\
(p C i / L)\end{array}$ & $\begin{array}{l}\text { Radon Flux } \\
\left(p C i / m^{2} \cdot s\right)\end{array}$ & $\begin{array}{c}\text { Radon } \\
\text { Concentration } \\
(p C i / L)\end{array}$ & $\begin{array}{c}\text { Radon FIux } \\
\left(p C i / m^{2} \cdot s\right)\end{array}$ \\
\hline 1 & 2.3 & 0.87 & 2.0 & 0.84 & 3.2 & 1.02 \\
\hline 2 & 2.0 & 0.85 & 2.0 & 0.72 & 3.1 & 1.07 \\
\hline 3 & 2.2 & 0.78 & 1.8 & 0.83 & 3.8 & 1.06 \\
\hline 4 & $2.1^{\circ}$ & 0.88 & 1.9 & 0.91 & 3.6. & 1.14 \\
\hline 5 & 2.1 & 0.86 & 2.1 & 0.99 & 4.1 & 1.22 \\
\hline 6 & 2.8 & 0.86 & 2.1 & 0.88 & 4.8 & 1.26 \\
\hline 7 & 1.9 & 0.73 & $1.6^{\mathrm{a}}$ & $0.71^{\mathrm{a}}$ & 5.2 & 1.13 \\
\hline 8 & 2.1 & 0.76 & 1.5 & 0.63 & 3.5 & 0.91 \\
\hline 9 & 1.9 & 0.55 & $1.5^{b}$ & $0.65^{\mathrm{b}}$ & 2.4 & 0.95 \\
\hline 10 & 1.8 & 0.71 & 1.5 & 0.64 & 1.5 & 0.72 \\
\hline 11 & 1.9 & 0.73 & & & 1.4 & 0.65 \\
\hline 12 & & & & & 1.4 & 0.66 \\
\hline 13 & 1.7 & 0.59 & & & 1.3 & 0.66 \\
\hline 14 & 1.8 & 0.50 & 1.8 & 0.57 & 1.4 & 0.70 \\
\hline 15 & 1.8 & 0.56 & 1.7 & 0.59 & 1.4 & 0.62 \\
\hline 16 & $24.7^{c}$ & $0.71^{c}$ & $9.6^{c}$ & $0.28^{c}$ & 1.3 & 0.56 \\
\hline 17 & 1.6 & 0.63 & 1.6 & 0.77 & 1.4 & 0.53 \\
\hline 18 & 2.0 & 0.82 & 1.4 & 0.86 & 1.6 & 0.67 \\
\hline 19 & 1.8 & 0.86 & 1.5 & 0.84 & 2.9 & 0.96 \\
\hline 20 & 1.8 & 0.87 & 1.4 & 1.06 & 3.0 & 1.13 \\
\hline 21 & 10.4 & 0.36 & 1.9 & 0.92 & 2.7 & 0.93 \\
\hline 22 & 1.8 & 0.86 & 1.8 & 1.04 & 2.9 & 1.06 \\
\hline 23 & 1.8 & 0.77 & 2.0 & 1.05 & 3.2 & 1.05 \\
\hline 24 & 1.8 & 0.80 & 1.8 & 0.88 & 3.4 & 1.12 \\
\hline
\end{tabular}

$a_{\text {Windy, }} \approx 50 \mathrm{mph}$.

$b_{\text {Pump fluctuation. }}$

$c_{\text {Blasting. }}$ 


\section{REFERENCES}

Abbiss, J., and N. Savignac. 1980. Personal communication (United Nuclear Corporation).

American Public Health Association. 1971. "Standard Methods for the Examination of Water and Wastewater." New York. pp. 617-628.

Anonymous. 1979. "United Nuclear recovers uranium by ripping parent sandstone." Eng. Min. J. 180:55,59.

Austin, S.R. 1975. "A laboratory study of radon emanation from.domestic uranium ores," pp. 151-163. In "Radon in Uranium Mining." IAEA-PL565/8. International Atomic Energy Agency.

Beckman, R.T. 1975. "Calibration Procedures for Radon and Radon Daughter Measurement Equipment." MESA Inf. Rep. IR 1005. Mining Enforcement and Safety Administration.

Boyle, R.W. 1907. "The absorption of the radioactive emanations by charcoal." J. Phys. Chem. 12:484.

Clements, W.E., and M.H. Wilkening. 1974. "Atmospheric pressure effects on ${ }^{222} \mathrm{Rn}$ transport across the earth-air interface." J. Geophys. Res. $79: 5025$.

Countess, R.J. 1977. "Measurement of Rn-222 flux with charcoal canisters," pp. 149-154. In A.J. Breslin (ed.),. "Radon Workshop:" HASL-325.

Dewar, J. 1903. "The absorption and thermal evolution of gases occluded in charcoa1." Proc. R. Soc. 74:122.

Environmental Data Service. 1979. "Local Climatological Data, Monthly Summary for Albuquerque, NM." National Climatic Center, Asheville, NC.

Hilpert, L.S., and V.L. Freeman. 1955. "Guides to uranium deposits in the Morrison Formation, Gallup-Laguna area, New Mexico." In "Geology of Uranium and Thorium." International Conference, U.S. Geological Survey.

Hoppe, R. 1978. "The jackpot at Jackpile is still paying off." Eng. Min: J. (November) : 86-90.

Momeni, M.H., J. Miranda, W. Kisieleski, and N. Kretz. 1979. "Continuous Measurement of Rn-222 Flux, Concentration and Working Level." Presented at the Health Physics Society Annual Meeting, 8-13 July 1979, Philadelphia, PA.

Rushing, D.R., W.J. Garcia, and D.A. Clark. 1964. "Analysis of effluents and environmental samples from uranium mills and of biological samples for radium, polonium and uranium," pp. 187-230. In "Radiological Health and Safety, in Mining and Milling of Nuclear Materials." International Atomic Energy Agency, Vienna. Vo1. 2. 
Rutherford, E. 1906. Letter to Nature magazine, October 6 .

Tanner, A.B. 1964. "Radon migration in the ground: a review," pp. 161-190. In J.A.S. Adams and W.M. Lowder (eds.), "The Natural Radiation Environment." University of Chicago Press. 
APPENDIX A. SUMMARY OF METEOROLOGICAL DATA MEASURED ON A 10-METER AND A 30-METER TOWER AT ST. ANTHONY MINE 
Table A.I. Meteorological Data from 6 September 1979

DATA FROM THE 30 anO 3 METER LEVFls OF tHe 30 METER TOWER

DATA FROM THE

UPPEN LEVEL

\begin{tabular}{|c|c|c|}
\hline $\begin{array}{l}\text { MONT } \\
\text { OAY }\end{array}$ & & HOUR \\
\hline 91 & 6 & 0 \\
\hline $9 /$ & 6 & 100 \\
\hline $9 /$ & 6 & 200 \\
\hline 91 & 6 & 300 \\
\hline 91 & 6 & 400 \\
\hline 91 & 6 & 500 \\
\hline 91 & 6 & 600 \\
\hline 91 & $h$ & 700 \\
\hline $9 /$ & 6 & 800 \\
\hline 91 & 6 & 900 \\
\hline 91 & $h$ & 1000 \\
\hline 91 & 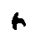 & 1100 \\
\hline 91 & $h$ & 1200 \\
\hline 91 & $t$ & 1300 \\
\hline 91 & h & 1400 \\
\hline 91 & 6 & 1500 \\
\hline 91 & 6 & 1600 \\
\hline $9 /$ & 6 & 1700 \\
\hline $9 /$ & 6 & 1800 \\
\hline 91 & 6 & 1900 \\
\hline $9 /$ & h & 2000 \\
\hline $9 /$ & 6 & 2100 \\
\hline 91 & $\begin{array}{l}6 \\
6\end{array}$ & $\begin{array}{l}2200 \\
2300\end{array}$ \\
\hline
\end{tabular}

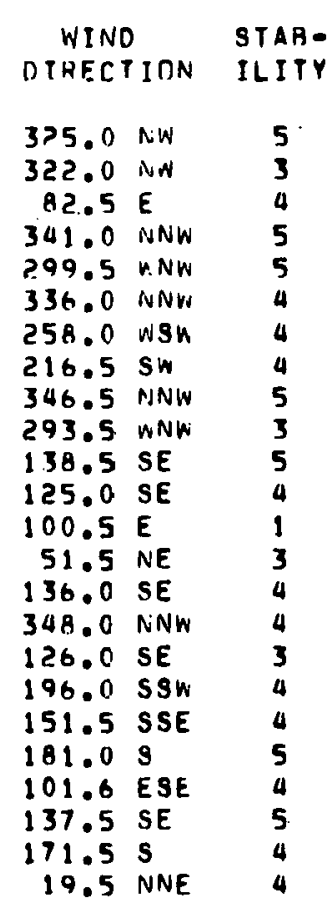

LOWER LEVEL

\begin{tabular}{|c|c|c|}
\hline $\begin{array}{l}\text { WIND } \\
\text { SPEED } \\
\text { (MPH) }\end{array}$ & \multicolumn{2}{|c|}{$\begin{array}{l}\text { WIND } \\
\text { DIRECTTON }\end{array}$} \\
\hline 2.6 & 2.2.5 5 & WNW \\
\hline 0.8 & 251.0 & WSW \\
\hline 3.1 & 131.5 & SE. \\
\hline 2.3 & 328.0 & NNW \\
\hline 3. & 266.5 & $w$ \\
\hline 1.2 & 275.0 & $w$ \\
\hline 3.1 & 192.0 & SSW \\
\hline 2.6 & 137.5 & SE \\
\hline 1.5 & 99.5 & $E$ \\
\hline 3.1 & 104.5 & ESE \\
\hline 3.8 & $8 B .0$ & E \\
\hline .0 & $4 \mathrm{~A} \cdot \mathrm{n}$ & NE \\
\hline 4.4 & 344.0 & NNW \\
\hline 5.4 & $14 ? .3$ & SE \\
\hline .2 & 27.0 & NNF \\
\hline 5.2 & 176.0 & 3 \\
\hline & $16 \mathrm{~h} .5$ & $\begin{array}{l}\text { SSE } \\
\text { SSF }\end{array}$ \\
\hline 2 & 181.0 & 8 \\
\hline 3.1 & 61.0 & ENE \\
\hline 1.6 & 158.5 & SSE \\
\hline 2. & $\begin{array}{l}172.0 \\
322.0\end{array}$ & \\
\hline
\end{tabular}

$S T A R$
$I L I T$
4
4
4
3
3
4
5
5
3
4
3
3
1
2
2
2
3
2
3
4
3
4
4
4

TEN METER TOWER

$\begin{array}{ccc}\text { WIND } & \text { TEMP } & \text { DEW } \\ \text { SPEED } & \text { (C) } & \text { POINT } \\ \text { (MPH) } & & \text { (C) } \\ 1.3 & 23.0 & -7.9 \\ 2.5 & 22.8 & -8.1 \\ 4.3 & 21.6 & -8.3 \\ 3.0 & 21.4 & -8.0 \\ 1.7 & 20.3 & -8.9 \\ 2.0 & 17.7 & -7.8 \\ 0.9 & 16.9 & -6.9 \\ 1.2 & 19.8 & -5.4 \\ 1.6 & 24.1 & -5.1 \\ 3.6 & 27.7 & -5.8 \\ 4.7 & 30.3 & -6.6 \\ 4.7 & 32.4 & -6.3 \\ 5.0 & 32.8 & -9.0 \\ 5.9 & 32.9 & -5.2 \\ 4.7 & 33.2 & -4.9 \\ 5.7 & 33.7 & -4.4 \\ 5.4 & 33.5 & -4.6 \\ 3.7 & 33.2 & -5.7 \\ 0.7 & 31.1 & -7.1 \\ 5.2 & 29.2 & -5.3 \\ 9.4 & 29.6 & -2.3 \\ 3.3 & 27.6 & -2.4 \\ 3.5 & 24.0 & -2.8 \\ 1.3 & 23.4 & -2.1 \\ & & \end{array}$

\section{UAILY SUMMARY}

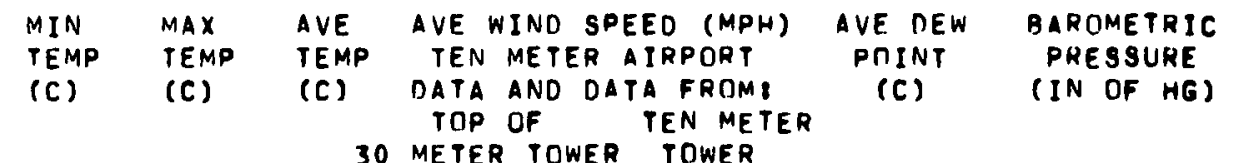

ST ANTHONY

$\begin{array}{llllll}16.9 & 33.7 & 26.8 & 5.1 & 3.6 & -5.7\end{array}$

ALBUDUERQUE

A IFPOR T

$\begin{array}{llll}17.2 & 36.7 & 27.2 & 9.2\end{array}$

9.2

1.7

24.82 
Táble A.2. Meteorological Data from 7 September 1979 "

DATA FRTM THE 30 AND 3 METER LEVELS OF THE 30 METER TOWER

DATA FROM THE

$$
\text { UPPER LEVEL }
$$

LOWER LEVEL

$\begin{array}{lcc}\text { WIND : WINA } & \text { STAR- } \\ \text { SPEED } & \text { OIRECTION } & \text { ILITY } \\ \text { (MPH) } & & \\ 1.5 & 16.5 \text { NNE } & 3\end{array}$

OAY HOUR

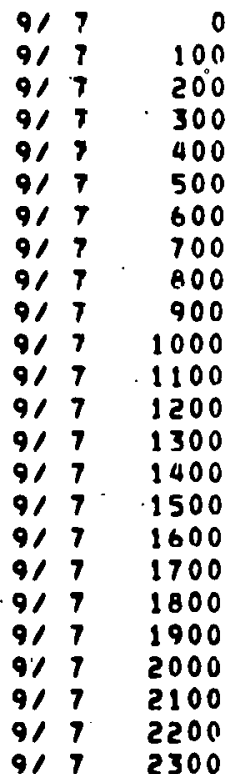

WINO WINA
SPEER DIPECTION SABP
(MPH)

4. 4

6.4

3.7

(3.0 E

$1.9360 .0 \mathrm{~N}$

$1.8 \quad 5.5 \mathrm{~N}$

$1.9272 .5 \mathrm{~W}$

1.6 15.0 NNE

2.4 35.5 NE

5.0 144.0 SE

$6.6 \quad 144.5 \mathrm{SE}$

$8.0 \quad 187.5 \mathrm{~S}$

$6.4 \quad 165.0 \mathrm{SSE}$

$6.6 \quad 164.0$ SSE

$5.2 \quad 126.6 \mathrm{SE}$

$5.7 \quad 192.0 \mathrm{SSW}$

B.4 $356.5 \mathrm{~N}$

$6.4 \quad 341.5 \mathrm{NNm}$

$5.7 \quad 214.0 \mathrm{SW}$

$4.8 \quad 106.5$ ESE $\begin{array}{rr}7.6 & 346.0 \\ 3.9 & 85.5 \mathrm{E}\end{array}$

4
5
5
4
6
4
5
4
5
5
4
4
4
4
4
4
4
4
4
5
5
5
4
5

1.5
2.4

$2.4 \quad 104.0$ NSF

$0.7 \quad 29.0$ NNE

$0.630 \mathrm{~h} .5 \mathrm{NN}$

1.0 2.82.5. WNW

$0.8 \quad 301.0 \mathrm{WNW}$

$1.1336 .0 \mathrm{NN}$

$0.8 \quad 333.5 \mathrm{NNW}$

$1.6 \quad 356.0 \mathrm{~N}$

$\begin{array}{lll}3.8 & 134.7 \mathrm{SE} \\ 4.1 & 51.5 \mathrm{SSE}\end{array}$

$6.3173 .0 \mathrm{~s}$

$5.8 \quad 159.0$ SSE

$5.7 \quad 193.5 \mathrm{SSW}$

3.1 25.5 NNE

$0.4 \quad 170.5 \mathrm{~s}$

$5.0-349.5 \mathrm{~N}$

$2.5 \quad 37.0 \mathrm{NE}$

$\begin{array}{ll}5.4 & 323.5 \mathrm{NW} \\ 4.2 & 329.0 \mathrm{NNW}\end{array}$

$\begin{array}{ll}4.2 & 329.0 \\ 3.8 & 186.0 \mathrm{~N}\end{array}$

$2.0 \quad 17.0$ NAE
2.5 .116 .9 ESE

3
3
4
5
5
5
4
4
4
4
4
4
4
3
3
4
4
4
4
5
4
6
4
5

TEMP .....

TEN METER TOWER

WINO TEMP OEW

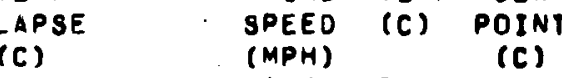

$\begin{array}{llll}0.5 & 1.5 & 22.5 & -1.8\end{array}$

$\begin{array}{llll}0.8 & 2.0 & 21.3 & -1.3\end{array}$

$\begin{array}{llll}0.5 & 2.6 & 19.1 & -1.3\end{array}$

$0.7 \quad 3.0 \quad 18.3 \quad-1.3$

$\begin{array}{llll}0.6 & 3.6 & 17.7 & -1.3\end{array}$

$\begin{array}{llll}0.9 & 2.3 & 17.0 & -1.2\end{array}$

$1.3 \quad 1.5 \quad 16.9 \quad-1.1$

$\begin{array}{rrrr}0.8 & 0.2 & 21.1 & 0.2 \\ -0.3 & 1.3 & 25.0 & 1.2\end{array}$

$-0.8$

$-1.6$

$-1.8$

$-2.4$

$-2.5$

$-2.3$

$-1.5$

$-2.0$

$-1.1$

$-1.0$

$-0.7$

$-0.3$

0.2

0.0

1.3
3.3

3.3
4.6

6.3

6.3
5.6
6.1

6.6

$\begin{array}{ll}25.0 & 1.2 \\ 26.9 & 1.6\end{array}$

$27.7 \quad 1.0$

28.50 .3

$29.0 \quad 0.3$

$29.7 \quad 0.2$

$\begin{array}{lll}3.1 & 31.3 \quad-1.0\end{array}$

$\begin{array}{lll}4.2 & 31.8 & -2.9\end{array}$

$\begin{array}{lll}5.8 & 31.7 & -3.6\end{array}$

$\begin{array}{lll}2.6 & 31.3 & -3.6\end{array}$

$\begin{array}{lll}5.5 & 30.9 & -3.3\end{array}$

$\begin{array}{lll}4.3 & 29.4 & -2.0\end{array}$

$\begin{array}{lll}4.3 & 29.4 & -2.0 \\ 1.5 & 29.0 & -1.0\end{array}$

$\begin{array}{lll}1.5 & 29.0 & -1.0 \\ 1.4 & 27.9 & -1.7\end{array}$

$3.3 \quad 25.4 \quad-2.8$

DAILY SUMMARY

\begin{tabular}{|c|c|c|c|c|c|c|c|c|}
\hline $\begin{array}{l}\text { MIN } \\
\text { TEMP }\end{array}$ & $\begin{array}{l}\text { MAX } \\
\text { TEMP }\end{array}$ & $\begin{array}{l}\text { AVE } \\
\text { TEMP }\end{array}$ & $\begin{array}{l}\text { AVE } \\
\text { TEN }\end{array}$ & $\begin{array}{l}\text { WINO } \\
\text { METE }\end{array}$ & $\begin{array}{l}\text { SPEED } \\
\text { ER AIR }\end{array}$ & $\begin{array}{l}\text { (MPH) } \\
\text { PORT }\end{array}$ & $\begin{array}{l}\text { AVE NEW } \\
\text { POINT. }\end{array}$ & $\begin{array}{l}\text { BARUMETRIC } \\
\text { PRESSURE }\end{array}$ \\
\hline (c) & (c) & (C) & $\begin{array}{l}\text { DATA } \\
\text { TOP }\end{array}$ & $\begin{array}{l}\text { AND } \\
\text { OF }\end{array}$ & DATA & $\begin{array}{l}\text { FROM: } \\
\text { N METER }\end{array}$ & (C) & (IN OF HG) \\
\hline
\end{tabular}
30 METER TOWER TOWER

ST. ANTHONY

MINE

A I KPOR T

16

$16.9 \quad 31.8 \quad 25.5 \quad 4.8$

$3.3-1.2$

$16.7 \quad 35.6 \quad 26.1 \quad 5.8$

5.8

5.6

24.86 
Table A.3. Meteorological Data from 8 September 1979

DATA. FROM THE 30 AND 3 METER LEVELS OF. THE 30 METER TDWER UPPER LEVEL

\begin{tabular}{|c|c|c|}
\hline \multicolumn{2}{|c|}{$\begin{array}{l}\text { MONTHA } \\
\text { DAY }\end{array}$} & HOUR \\
\hline 91 & B & 0 \\
\hline 91 & A & 1.00 \\
\hline 91 & 8 & 200 \\
\hline 91 & A & 300 \\
\hline 91. & B & 400 \\
\hline 91 & A & 500 \\
\hline 91 & B & 600 \\
\hline 91 & A & 700 \\
\hline 9.1 & A & 800 \\
\hline 91 & A & 9.00 \\
\hline 91 & A & 1000 \\
\hline $9 /$. & $\theta$ & 1100 \\
\hline 91 & B & 1200 \\
\hline 91 & A & 1300 \\
\hline 91 & A & 1400 \\
\hline 91 & A & 1500 \\
\hline 91 & 8 & 1600 \\
\hline & ค & 1700 \\
\hline 91 & A & 1800 \\
\hline & 8 & 1900 \\
\hline 91 & B & 2000 \\
\hline & A & $210 n$ \\
\hline 91 & 8 & 2200 \\
\hline 91 & A & 2300 \\
\hline
\end{tabular}

\section{LOWER LEVEL}

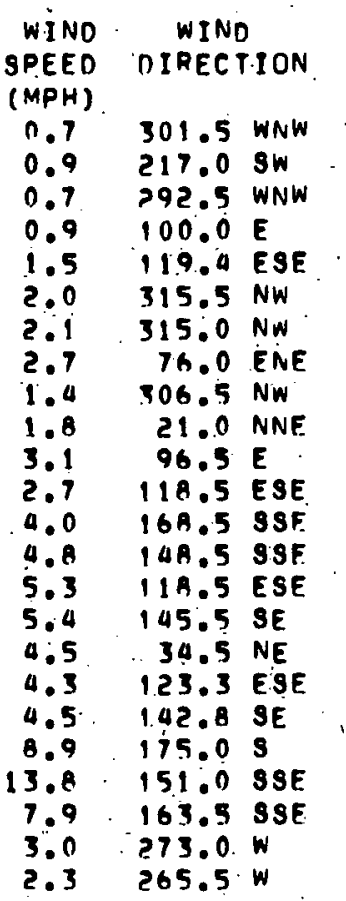

DAILY SUMMARY
DATA FROM THE TEN METER TOWER

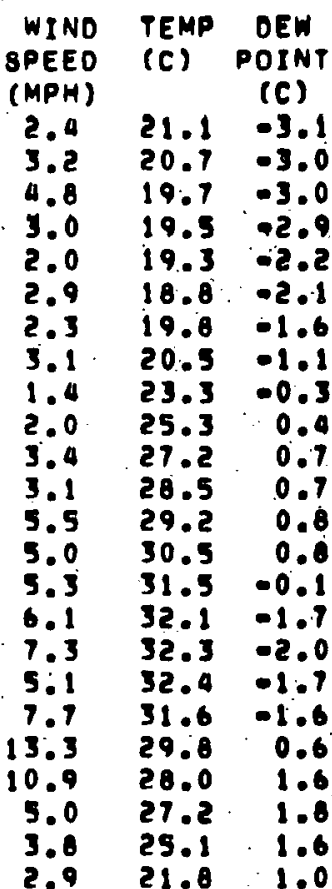

$$
\begin{aligned}
& \text { MIN MAX AVE AVE WINO SPEED (MPH) AVE.DEW AAROMETRIC } \\
& \text { TEMP TEMP TEMP TEN METER AIRPORT PNINT PRESSURE } \\
& \begin{array}{lllll}
\text { (C) } & \text { (C) } & \text { (C) DATA AND DATA FROM: } & \text { (C) } \\
\text { (IN OF HG) }
\end{array} \\
& \begin{array}{l}
30 \text { METER TOWER TOWER } \\
\text { TON TET }
\end{array}
\end{aligned}
$$

\begin{tabular}{|c|c|c|c|c|c|c|}
\hline MINE & 18.8 & 32.4 & 25.6 & 6.2 & 4.6 & -0.7 \\
\hline $\begin{array}{l}\text { AIRPORT } \\
\end{array}$ & 18.9 & 34.4 & 26.7 & 9.2 & 9.2 & 0.9 \\
\hline
\end{tabular}


Table A.4. Meteorological Data from 9 September 1979

DATA FROM THE 30 AND 3 METER LEVELS OF THE 30 METER TOWER UPPER LEVEL

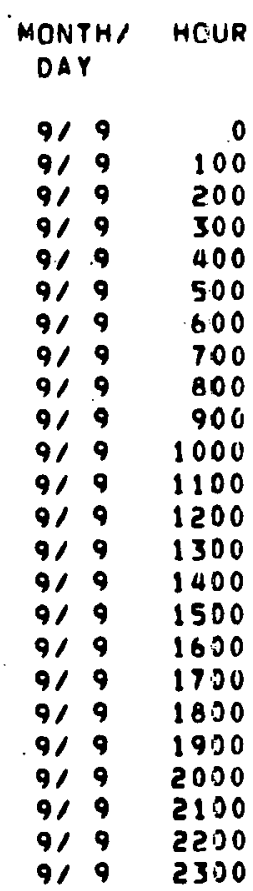

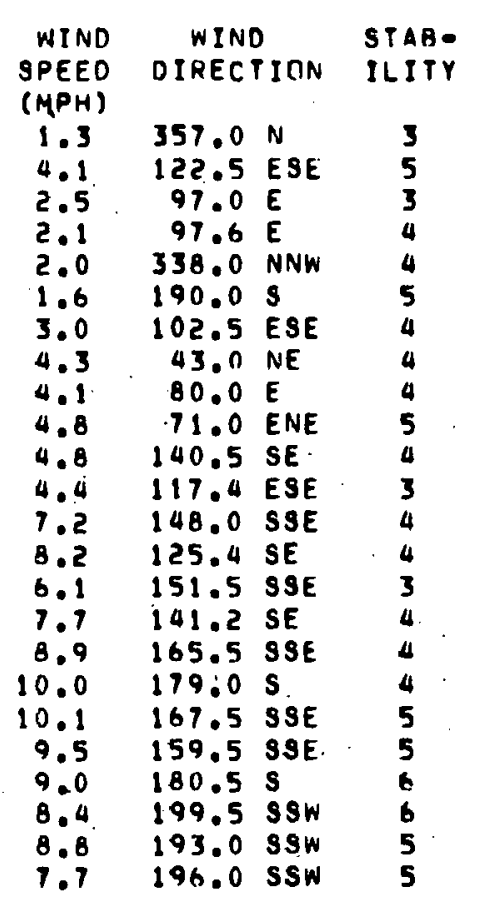

LOWER. LEVEL

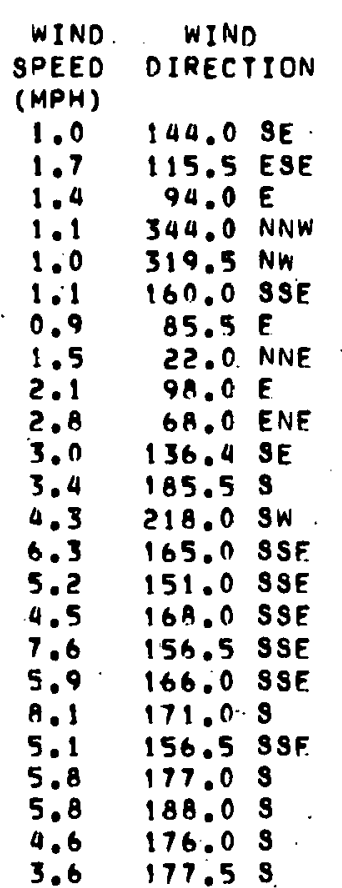

DATA FROM THE TEN METER TOWER

$\begin{array}{ccc}\text { WINO } & \text { TEMP } & \text { OEW } \\ \text { SPEED } & \text { (C) } & \text { POINT } \\ \text { (MPH) } & & \text { (C) } \\ 2.2 & 20.9 & 0.3 \\ 1.5 & 20.2 & 0.2 \\ 1.4 & 19.2 & 0.2 \\ 1.9 & 18.8 & -0.2 \\ 2.0 & 16.2 & 0.1 \\ 2.5 & 17.7 & 0.2 \\ 2.2 & 17.4 & 0.1 \\ 2.2 & 17.5 & 0.1 \\ 0.9 & 21.6 & 1.1 \\ 3.3 & 24.3 & 1.7 \\ 2.6 & 25.3 & 1.4 \\ 3.8 & 26.9 & 1.6 \\ 6.3 & 27.4 .4 & 0.7 \\ 6.5 & 28.5 & -0.1 \\ 6.4 & 29.2 & 0.0 \\ 7.0 & 29.5 & -0.7 \\ 6.3 & 30.1 & -1.9 \\ 6.7 & 30.2 & -2.4 \\ 5.8 & 30.1 & -3.1 \\ 5.2 & 29.2 & -2.6 \\ 3.3 & 27.7 & -2.6 \\ 2.1 & 26.2 & -3.1 \\ 2.8 & 21.9 & -3.0 \\ 1.8 & 20.1 & -2.7\end{array}$

DAILY SUMMARY

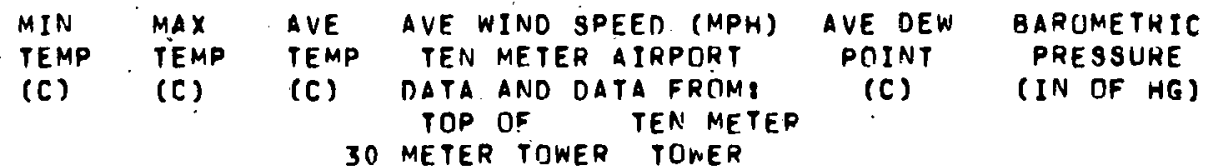

ST. ANTHONY

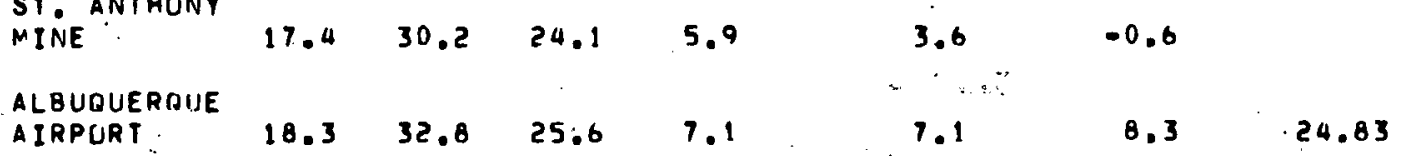


Table A.5: Meteorological Data from 10 September 1979

DATA FRTM THE 30 aND 3 METER LEVELS OF THE 30 METER TUWER

DATA FROM THE

$$
\text { UPPER LEVEL }
$$

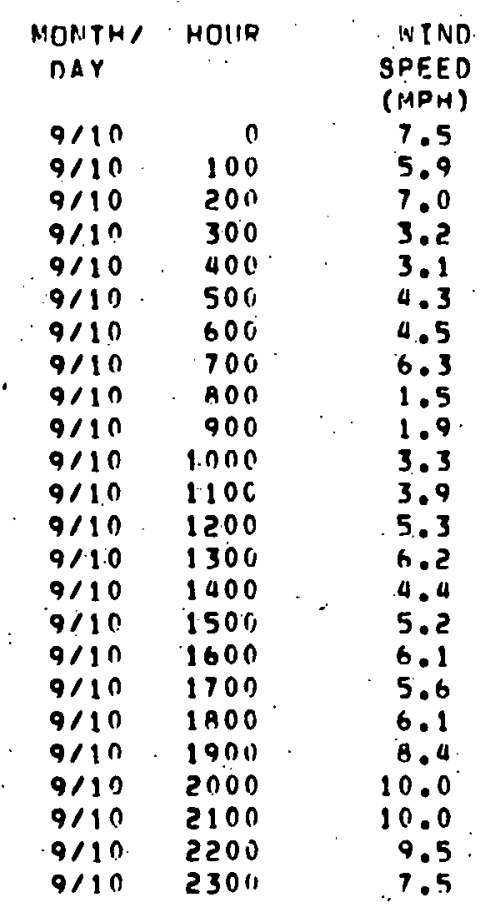

$$
\begin{aligned}
& \text { WIND STABO } \\
& \text { DIHECTION ILITY }
\end{aligned}
$$

$242.0 \mathrm{WSW}$ $222.5 \mathrm{sW}$ $216.5 \mathrm{SW}$ 246.0 WSW $215.0 \mathrm{sW}$ 74.5 ENE 39.5 NE 64.5 ENE 50.5 NE 74.5 ENE 162.C SSE $142 . h \cdot S E$ 148.5 SSE 125.3 SE 252.0 W9W $218.0 \mathrm{sW}$ $143.5 \mathrm{SE}$ 196.0 SSW $167.5 \mathrm{SSE}$ 196.5 5SW $17 \mathrm{~h} .5 \mathrm{~s}$ $186.0 \mathrm{~s}$ $219.5 \mathrm{sW}$

6
5
6
4
3
5
4
5
4
4
4
3
3
4
3
2
3
4
4
5
6
6
5
5

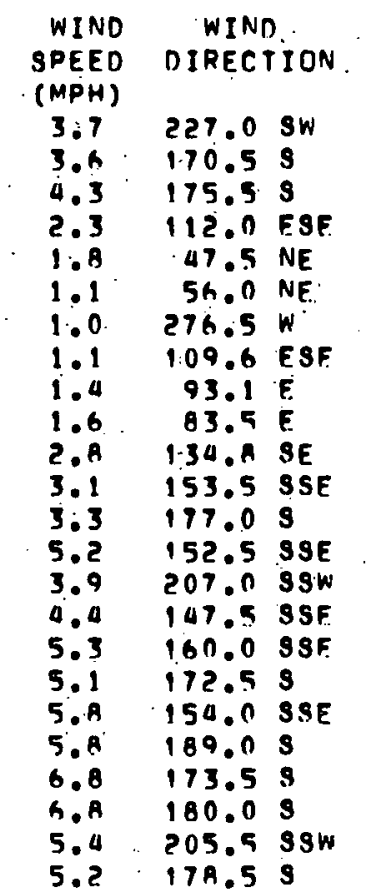

STAR- TEMP ILITY LAPSE

5 (C)

$\begin{array}{ll}5 & 1.3 \\ 5 & 1.8\end{array}$

$5 \quad 2.3$ $5 \quad 1.6$

DAILY SUMMARY

$$
\begin{aligned}
& \begin{array}{l}
\text { MIN MAX AVE AVE WINO SPEED (MPH) AVE DEW PAROMETRIC } \\
\text { TEMP TEMP TEMP TEN.METER AIRPORT POINT PRESSURE }
\end{array} \\
& \begin{array}{l}
\text { TEMP TEMP TEMP TEN METERAIRPORT POINT POI PRESSURE } \\
\text { (C) }
\end{array} \\
& \text { (C) (C) (C) DATA ANO DATA FROME: } \\
& \text { 30. METER TOWER TOWER : }
\end{aligned}
$$

7.3 
Table A.6." Meteorological Data from 11 September 1979

DATA FROM THE 30 AND 3 meter LEVELS OF THE 30 meter tOWER

$\begin{array}{lr}\text { MONTHI } & \text { HOUR } \\ \text { OAY } & \\ & \\ 9 / 11 & 0 \\ 9111 & 100 \\ 9111 & 200 \\ 9111 & 300 \\ 9111 & 400 \\ 9111 & 500 \\ 9111 & 600 \\ 9111 & 700 \\ 9111 & 800 \\ 9111 & 900 \\ 9111 & 1000 \\ 9111 & 1100 \\ 9111 & 1200 \\ 9111 & 1300 \\ 9111 & 1400 \\ 9111 & 1500 \\ 9111 & 1600 \\ 9111 & 1700 \\ 9111 & 1800 \\ 9111 & 1900 \\ 9111 & 2000 \\ 9111 & 2100 \\ 9111 & 2200 \\ 9111 & 2300 \\ 911 & \\ & \end{array}$
UPPER LEVEL

\section{LOWER. LEVEL}

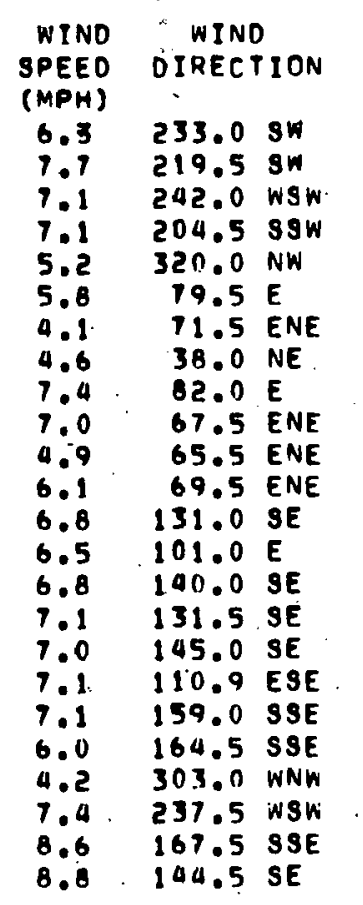

STAB-
ILITY
5
6
5
5
3
1
4
5
4
4
4
4
4
4
4
4
4
4
4
4
4
5
4
5

WIND
SPEED
(MPH)
Q.a

(MPH)

0.6
3.6

$4 . B \quad 206.5 \mathrm{SSW}$

$2.7345 .0 \mathrm{NNW}$

$2.1 \quad 19.4 \mathrm{E}$

O.B 110.0 ESE

$1.6 \quad 13.5$ NNE

3.2 43.0 NE.

3.3 5B.5 ENF

$3.5 \quad 0.5 \mathrm{~N}$

$\begin{array}{rr}3.5 & 3 a .0 \\ 5.2 & 140.0 \mathrm{SE}\end{array}$

4.3 3?.5 NNE

5.9 145.5 SE

$6.5100 .5 \mathrm{SE}$

h.1 153.5 SSE

4.5 150.5 SSE

5.4. 164.0 SSE

5.0 159.0 SSE

$1.7 \quad 273.5 \mathrm{~W}$

6.4240 .0 WSW

5.3 16月.0. SSE

7.0 144.0 SE

$\begin{array}{cc}\text { STAR } & \text { TEMP } \\ \text { ILITY LAPSE } & \text { LAC } \\ & \text { (C) } \\ 5 & 1.4 \\ 5 & 2.3 \\ 5 & 2.2 \\ 5 & 1.6 \\ 4 & 0.5 \\ 4 & 0.6 \\ 4 & 0.9 \\ 4 & 0.6 \\ 4 & 0.0 \\ 4 & -0.9 \\ 3 & -1.0 \\ 4 & -1.6 \\ 3 & -1.9 \\ 4 & -1.6 \\ 4 & -2.0 \\ 4 & -2.2 \\ 4 & -1.9 \\ 4 & -1.5 \\ 5 & -1.0 \\ 4 & 0.2 \\ 4 & 0.0 \\ 4 & -0.1 \\ 4 & 0.0 \\ 4 & -0.2\end{array}$

DATA FROM THE

\section{TEN METER TOWER}

$\begin{array}{ccc}\text { WINO } & \text { TEMP } & \text { DEW } \\ \text { SPEEO } & \text { (C) } & \text { POINT } \\ \text { (MPH) } & & \text { (C) } \\ 2.3 & 20.9 & -3.6 \\ 3.4 & 20.4 & -2.2 \\ 1.3 & 18.9 & -2.6 \\ 2.7 & 18.4 & -2.3 \\ 2.4 & 18.6 & -2.1 \\ 2.0 & 20.0 & -2.6 \\ 2.9 & 17.6 & -2.6 \\ 0.6 & 17.7 & -2.4 \\ 1.6 & 21.6 & -1.7 \\ 3.4 & 23.6 & -1.6 \\ 3.6 & 25.3 & -1.2 \\ 5.6 & 27.0 & -1.4 \\ 5.6 & 27.7 & -1.2 \\ 5.5 & 28.2 & -1.4 \\ 6.4 & 29.1 & -1.2 \\ 6.8 & 30.2 & -1.1 \\ 7.9 & 30.3 & -1.4 \\ 7.1 & 30.4 & -2.2 \\ 6.2 & 30.2 & -2.0 \\ 5.4 & 29.0 & -1.9 \\ 3.4 & 26.3 & -1.7 \\ 9.1 & 27.4 & -1.1 \\ 11.8 & 25.6 & 0.3 \\ 5.4 & 25.0 & 0.4 \\ 1.4 & & \end{array}$

DAILY SIIMMARY

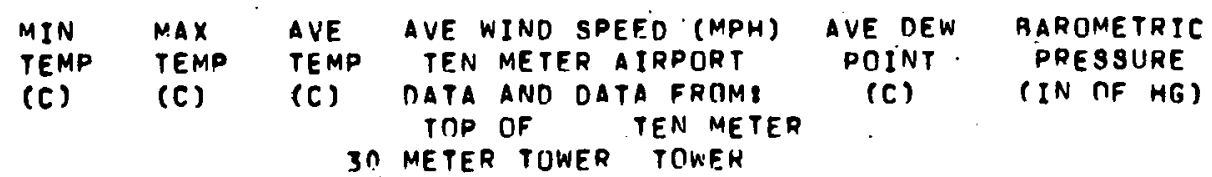

$\begin{array}{lccccccc}\text { ST. ANTHONY } & & & & & \\ \text { MINE } & 17.6 & 30.4 & 24.5 & 0.5 & 4.5 & -1.7 \\ \text { ALBUDUEROUE } & 16.7 & 34.4 & 25.6 & 9.1 & 9.1 & 6.7 & 24.72 \\ \text { AIRPOPT } & 16.7 & \end{array}$


Table A.7. Meteorological Data from 12 September 1979

DATA FROM THE 30 AND 3 METER LEVELS DF THE 30 METER TOWER

$$
\text { UPPER LEVEL }
$$

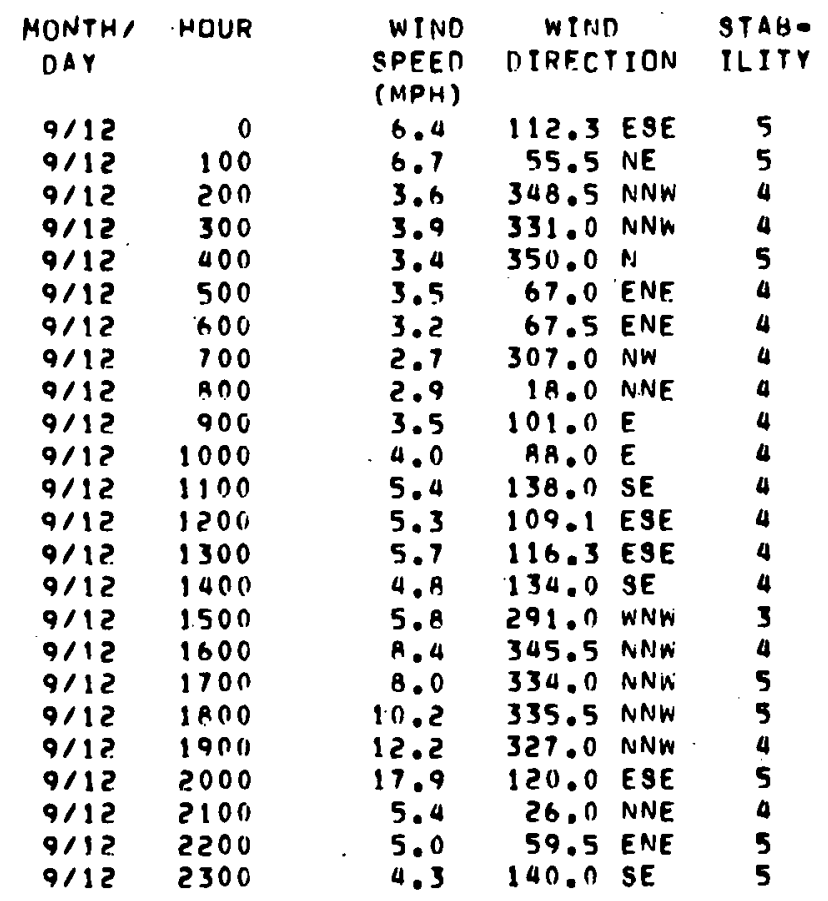

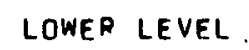

LOWER LEVEL

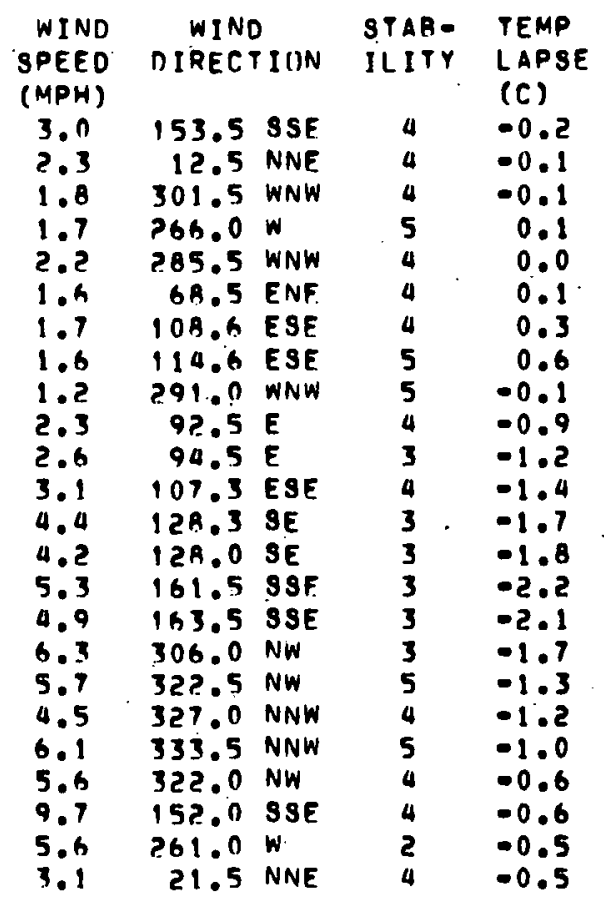

DATA FROM THE TEN METER TOWER

$\begin{array}{ccc}\text { WIND } & \text { TEMP } & \text { DEW } \\ \text { SPEED } & \text { (C) } & \text { POINT } \\ \text { (MPH) } & & \text { (C) } \\ 4.6 & 24.3 & -0.9 \\ 3.4 & 23.6 & -0.7 \\ 2.8 & 21.7 & -1.1 \\ 2.2 & 20.8 & -1.3 \\ 1.9 & 19.7 & -1.3 \\ 1.5 & 18.2 & -1.7 \\ 1.6 & 17.0 & -1.9 \\ 2.7 & 17.1 & -1.3 \\ 0.9 & 20.4 & -0.8 \\ 1.6 & 23.3 & -0.6 \\ 2.6 & 24.6 & -0.0 \\ 3.2 & 26.8 & -0.4 \\ 3.9 & 28.3 & -0.6 \\ 3.9 & 29.4 & -1.1 \\ 9.3 & 30.3 & -2.7 \\ 5.0 & 30.9 & -5.0 \\ 7.0 & 32.3 & -5.2 \\ 5.8 & 32.2 & -6.0 \\ 7.8 & 32.1 & -6.6 \\ 10.5 & 29.1 & -3.8 \\ 10.7 & 27.6 & -0.9 \\ 0.2 & 26.3 & -0.7 \\ 3.4 & 24.8 & -0.7 \\ 2.5 & 23.8 & -0.8 \\ 1.9 & & \end{array}$

\section{DAILY SUMMARY}

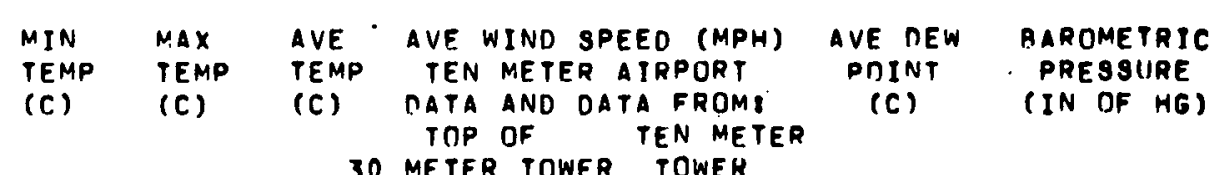
30 METER TOWER TOWER

ST. ANTHONY

MINE

$17.0 \quad 32.3 \quad 25.2 \quad 5.9$

4.1

$-1.9$

alaUOIIERTIJE AIRPORT

$\begin{array}{llll}16.1 & 35.0 \quad 25.6 & 12.7\end{array}$

12.7

6.1

24.72 
Table A.8. Meteorological Data from 13 September 1979

DATA FROM THE 30 ANO I METER LEVELS OF THE 30 METER TOWER

DATA FROM THE

$$
\text { UPPER LEVEL }
$$

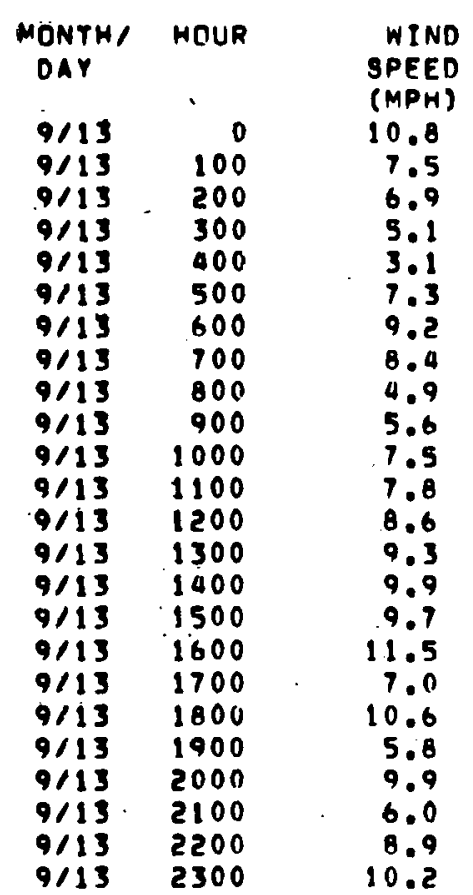

WIND
OIRECTION ILITY

111.0 ESE

115.5 ESE

112.2 ESE

$139.0 \mathrm{SE}$

$199.035 \mathrm{~W}$

$248.0 \mathrm{WSW}$

$204.593 \mathrm{~W}$

$206.053 W$

155.5 S9E

$179.5 \mathrm{~s}$

$151.5 \mathrm{SSE}$

156.5 SSE

152.0 SSE

$175.5 \mathrm{~S}$

$149.0-33 E$

$170.0 \mathrm{~S}$

57.0 ENE

31.0 NNE

167.0 SSE

$177.5 \mathrm{~s}$

247.5 WSW

$224.0 \mathrm{sw}$

$215.0 \mathrm{sw}$

5
5
5
4
4
5
6
6
4
4
4
4
4
4
4
5
3
3
4
4
5
5
5
5

LOWER LEVEL

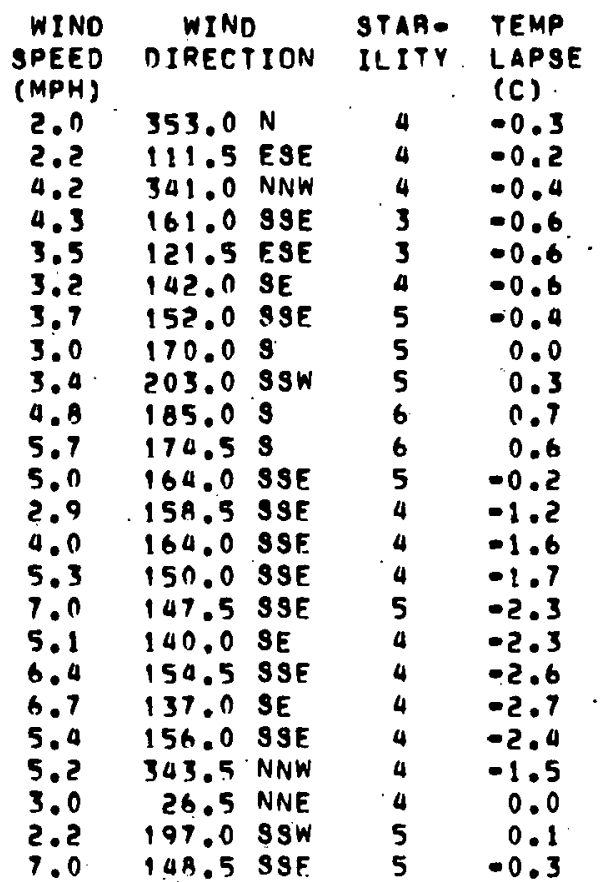

TEN METER TOWER

$\begin{array}{ccc}\begin{array}{c}\text { WIND } \\ \text { SPEED }\end{array} & \text { TEMP } & \text { DEW } \\ \text { POINT } & \text { POP } \\ \text { (MPH) } & & \text { (C) } \\ 7.1 & 23.2 & 0.6 \\ 5.5 & 21.5 & 2.9 \\ 3.8 & .20 .6 & 2.9 \\ 2.7 & 20.5 & 2.4 \\ 2.3 & 18.8 & 2.3 \\ 2.0 & 17.2 & 0.8 \\ 2.0 & 17.1 & 1.3 \\ 2.6 & 16.5 & 0.6 \\ 2.5 & 18.6 & 1.3 \\ 3.9 & 19.4 & 1.1 \\ 5.7 & 20.3 & 1.2 \\ 6.9 & 21.6 & 1.3 \\ 6.9 & 23.2 & 0.9 \\ 7.8 & 24.6 & 1.0 \\ 6.0 & 26.1 & 1.1 \\ 7.4 & 27.6 & 0.6 \\ 6.8 & 22.3 & 4.7 \\ 6.8 & 23.5 & 0.3 \\ 4.7 & 23.0 & 2.2 \\ 4.2 & 22.7 & 2.6 \\ 5.5 & 22.4 & 2.1 \\ 2.5 & 22.1 & 1.7 \\ 3.8 & 22.0 & 1.2 \\ 4.0 & 21.5 & 1.2\end{array}$

\section{DAILY SIJMMARY}

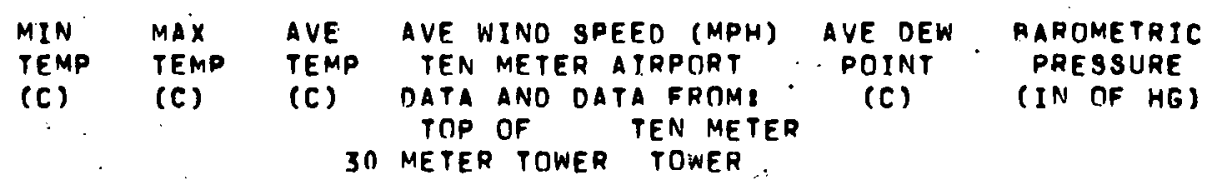

ST. ANTHONY

MINE

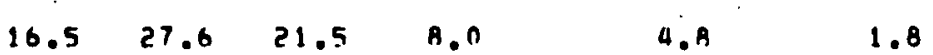

ALEUOUERQUE

AIRPORT

$15.6 \quad 30.6 \quad 23.3 \quad 12.8$

1?.8

8. 3

24.77 
Table A.9. Meteorological Data from 14 September 1979

DATA FROM THE 30 anO 3 METER LEVELS DF THE 30 METER TOWER

DATA FROM THE UPPER LEVEL

LOWER LEVEL

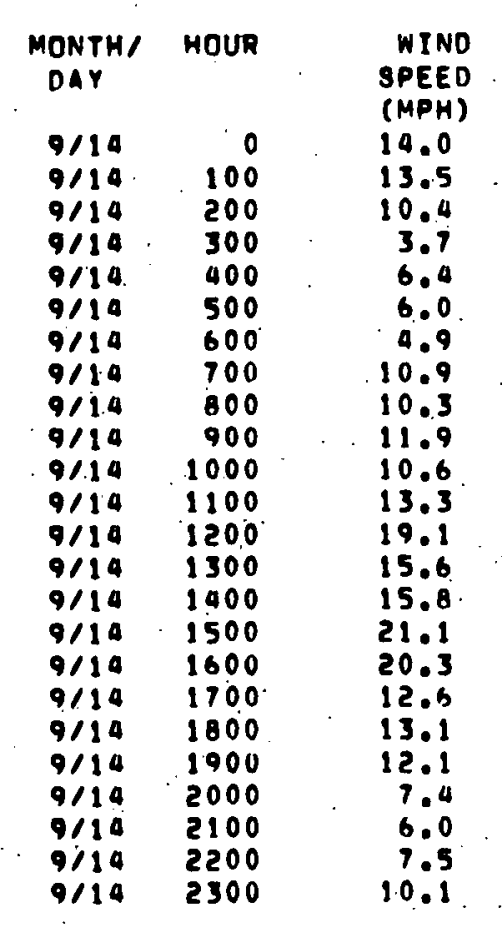

WIND
OIRECTION

32.0 NNE
18.5 NNE
15.0 NNE
92.0 NE
105.5 ESE
101.5 ESE
71.5 ENE
77.5 ENE
71.0 ENE
66.0 ENE
61.5 ENE
280.5 W
59.5 ENE.
256.0 WSW
247.0 NSW
241.5 WSW
227.0 SW
238.5 WSW
19.5 NNE.
354.0 N
206.5 SSW
212.5 SSW
193.0 SSW
199.0 SSW

STAB-

ILITY
SPEEO
(MPH)

WIND: DIRECTION ILITY LAPSE

$4.3 \cdot 151.5$ SSE

$4.7 \quad 236.5 \mathrm{WSW}$

$4.8 \quad 206.5 \mathrm{ssw}$

$3.8220 .5 \mathrm{sW}$

6.3 2.12.0 $39 \mathrm{~W}$

$6.4 \quad 191.5 \mathrm{sSW}$

B.1 $203.5 \mathrm{SSW}$

$1.6 \quad 175.5 \mathrm{~s}$

$8.4 \quad 188.5 \mathrm{~s}$

$4.8 \quad 176.0 \mathrm{~S}$

1.8
3.4 7.0 ENE

$3.1 \quad 37.5$ NE

$4.3 \quad 99.5 \mathrm{E}$

5.9 23.5 NNE

7.7 31.5 NNF

$9.6 \quad 34.5 \mathrm{NE}$

$8.3 \quad 30.0$ NNE

7.5 29.0 NNE

5.8 26.5 NNE

6.7 20.0 NNE

$4.350 .5 \mathrm{NE}$

3.a. 5B:0 ENE

$3.6 \quad 25.5$ NNE
ILITY LAPSE
(C)

$\begin{array}{ll}4 & 0.1 \\ 5 & 0.4\end{array}$

0.4

0.7

0.7

0.6

0.9

1.4

1.5

1.2
-0.2

$-0.2$

-0.2
-0.4

-0.4
-0.4

$-0.8$

$-1.0$

$-1.0$

-1.0
-0.9

-0.9
-0.8

$-0.7$

$-0.7$

$-0.5$

$-0.4$

$-0.4$
TEN MEPER TOWER

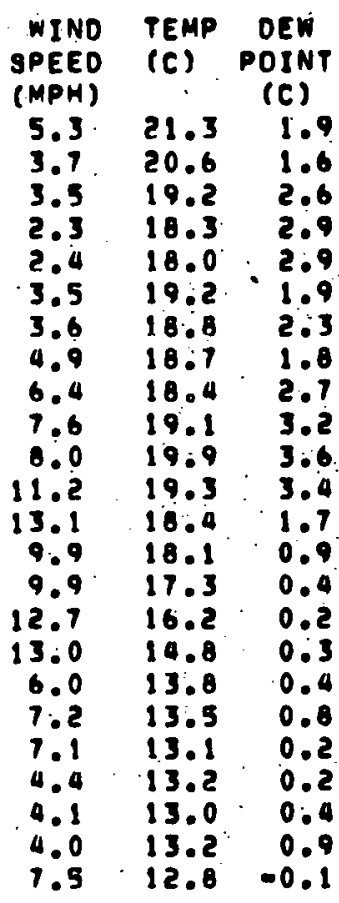

DAILY SUMMARY

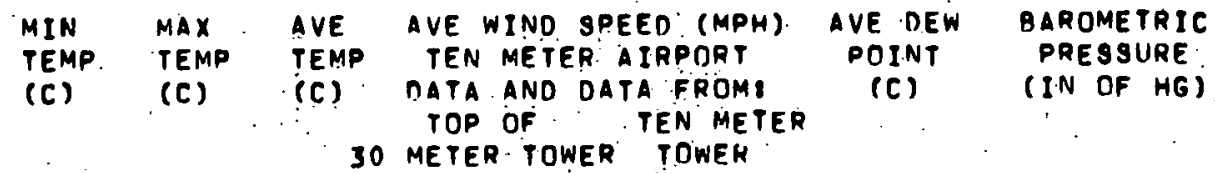

ST: ANTHONY

MINE

$12.8 \quad 21.3 \quad 17.0 \quad 11.5$

6.7

1.5

ALBIJQUERDUE AIRPORT

$8.9 \quad 18.9 \quad 13.9 \quad 23.6$

23.6

6.7

24.86 
Table A.10. Meteorological Data from 15 September 1979

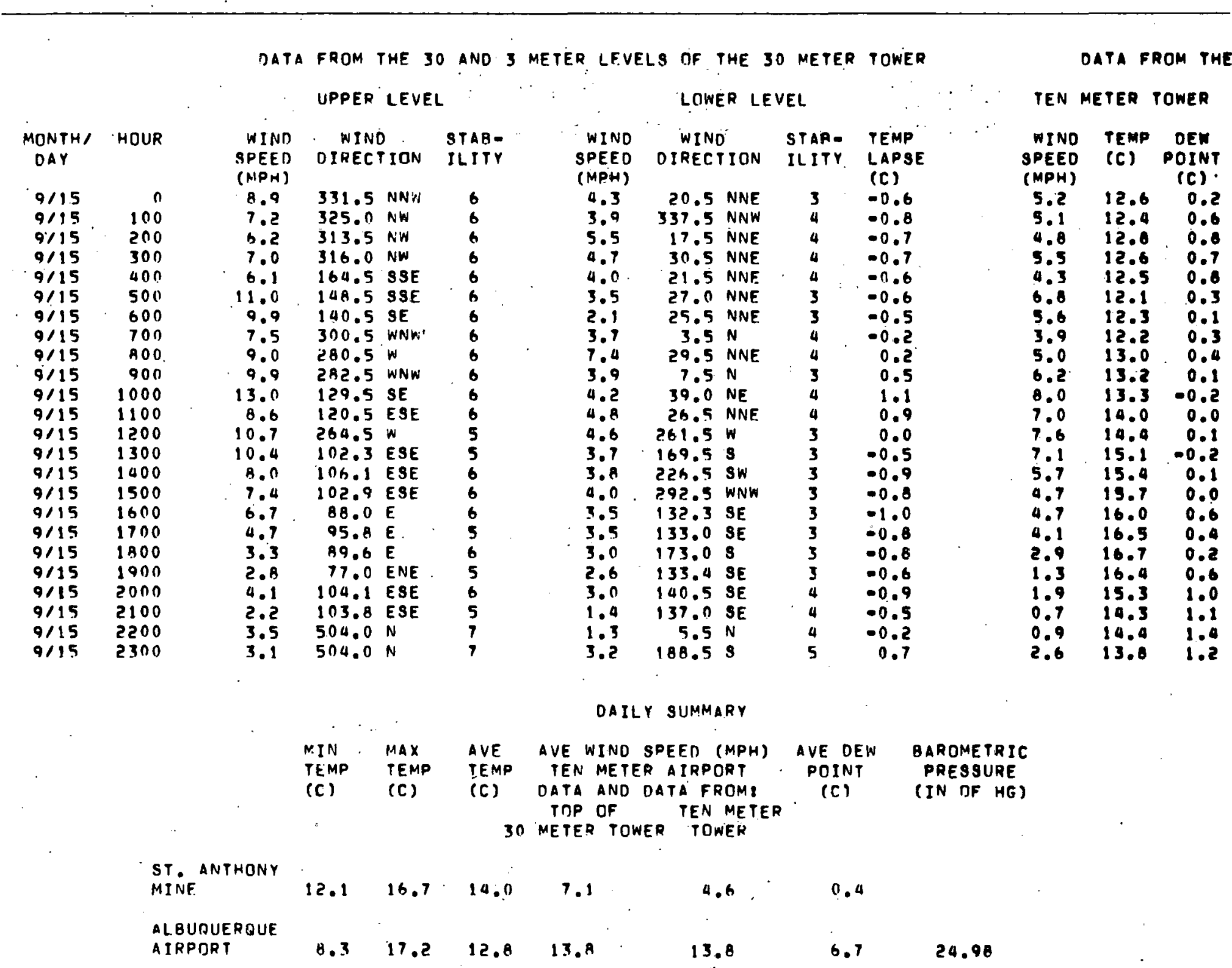


Table A.11. Meteorological Data from 16 September 1979

DATA FROM THE 30 ANO 3 METER LEVELS OF THE 30 meter TOWEA UPPER LEVEL

$\begin{array}{lr}\text { MONTH/ } & \text { HOUR } \\ \text { OAY } & \\ & \\ 9 / 16 & \\ 9 / 16 & 100 \\ 9 / 16 & 200 \\ 9 / 16 & 300 \\ 9 / 16 & 900 \\ 9 / 16 & 500 \\ 9 / 16 & 600 \\ 9 / 16 & 700 \\ 9 / 16 & 800 \\ 9 / 16 & 900 \\ 9116 & 1000 \\ 9 / 16 & 1100 \\ 9 / 16 & 1200 \\ 9 / 16 & 1300 \\ 9 / 16 & 1900 \\ 9 / 16 & 1500 \\ 9 / 16 & 1600 \\ 9116 & 1700 \\ 9 / 16 & 1800 \\ 9 / 16 & 1900 \\ 9 / 16 & 2000 \\ 9 / 16 & 2100 \\ 9 / 16 & 2200 \\ 9 / 16 & 2300\end{array}$

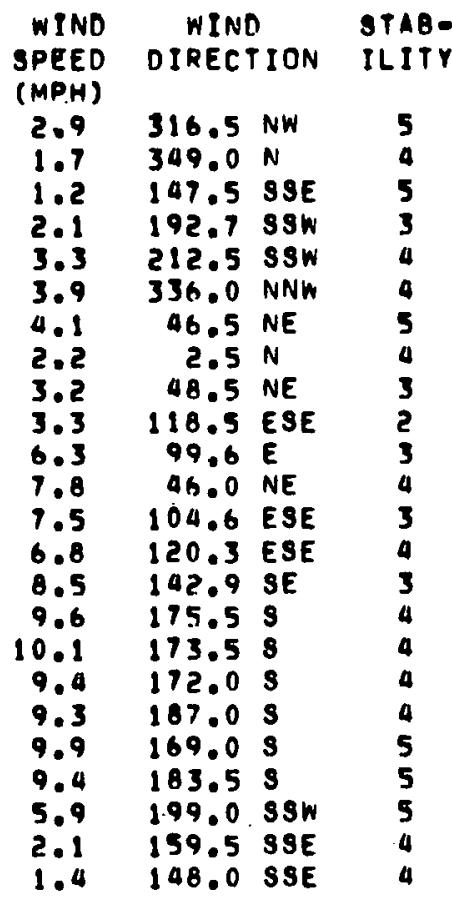

LOWER LEVEL

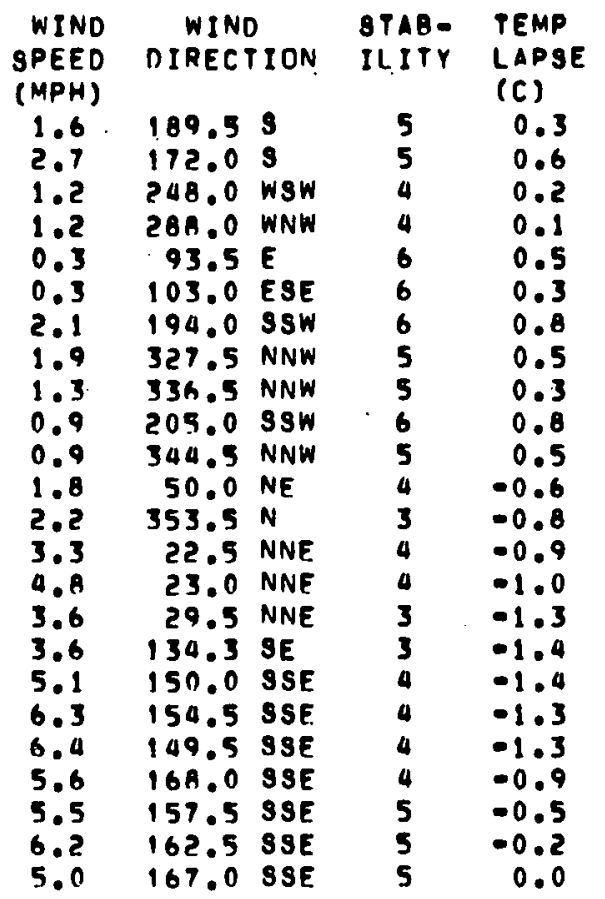

DATA FROM THE TEN METER TOWER

$\begin{array}{ccc}\text { WINO } & \text { TEMP } & \text { OEW } \\ \text { SPEEO } & \text { (C) } & \text { POINT } \\ \text { (MPH) } & & \text { (C) } \\ 1.2 & 14.0 & 1.9 \\ 1.6 & 13.4 & 1.3 \\ 1.6 & 12.5 & 1.3 \\ 2.8 & 12.9 & 0.0 \\ 9.3 & 12.9 & 0.8 \\ 1.5 & 13.3 & 1.0 \\ 1.8 & 12.8 & 0.8 \\ 2.4 & 12.0 & 0.4 \\ 1.6 & 14.0 & 2.0 \\ 1.7 & 16.6 & 2.8 \\ 4.6 & 18.8 & 2.4 \\ 5.7 & 20.1 & 2.1 \\ 5.3 & 20.8 & 2.3 \\ 6.3 & 20.9 & 2.6 \\ 7.4 & 21.5 & 2.3 \\ 6.7 & 21.4 & 2.7 \\ 6.8 & 21.4 & 2.7 \\ 6.4 & 21.1 & 2.6 \\ 6.4 & 20.6 & 2.9 \\ 6.9 & 19.5 & 3.0 \\ 6.2 & 18.9 & 2.9 \\ 3.7 & 17.9 & 2.1 \\ 1.5 & 17.7 & 2.6 \\ 1.1 & 17.1 & 3.0\end{array}$

\section{DAILY SUMMARY}

\begin{tabular}{|c|c|c|c|c|c|c|}
\hline $\begin{array}{l}\text { MIN } \\
\text { TEMP }\end{array}$ & $\begin{array}{l}\text { MAX } \\
\text { TEMP }\end{array}$ & $\begin{array}{l}\text { AVE } \\
\text { TEMP }\end{array}$ & $\begin{array}{l}\text { AVE WIND } \\
\text { TEN METER }\end{array}$ & $\begin{array}{l}\text { SPEED (MPH) } \\
\text { R AIRPORT }\end{array}$ & $\begin{array}{l}\text { AVE OEW } \\
\text { POINT }\end{array}$ & $\begin{array}{l}\text { BAROME TRIC } \\
\text { PRESSURE }\end{array}$ \\
\hline (c) & (C) & (C) & $\begin{array}{ll}\text { DATA AND } & \\
\text { TOP OF } & \end{array}$ & $\begin{array}{l}\text { DATA FROM: } \\
\text { TEN METER }\end{array}$ & (C) & (IN OF HG) \\
\hline
\end{tabular}

\begin{tabular}{|c|c|c|c|c|c|c|c|}
\hline $\begin{array}{l}\text { ST ANTHONY } \\
\text { MINE }\end{array}$ & 12.0 & 21.5 & 17.1 & 5.5 & 4.0 & 2.0 & \\
\hline IIRPORT & 8.3 & 22.8 & 15.6 & 7.9 & 7.9 & 8.9 & 29.91 \\
\hline
\end{tabular}


Table A.12. Meteorological Data from 17 September 1979

DATA FROM THE 30 AND 3 METER LEVELS OF THE 30 METER TOWER UPPER LEVEL

$\begin{array}{lr}\text { MONTH, } & \text { HOUR } \\ \text { DAY } & \\ & \\ 9 / 17 & 0 \\ 9 / 17 & 100 \\ 9117 & 200 \\ 9117 & 300 \\ 9117 & 400 \\ 9117 & 500 \\ 9 / 17 & 200 \\ 9117 & 700 \\ 9117 & 600 \\ 9117 & 900 \\ 9117 & 1000 \\ 9117 & 1100 \\ 9 / 17 & 1200 \\ 9117 & 1300 \\ 9117 & 1400 \\ 9117 & 1500 \\ 9117 & 1600 \\ 9117 & 1700 \\ 9117 & 1800 \\ 9117 & 1900 \\ 9117 & 2000 \\ 9117 & 2100 \\ 9117 & 2200 \\ 9117 & 2300\end{array}$

WIND
DIRECTION
114.0 ESE
207.0 SSW
$142.59 \mathrm{SE}$
$161.5 \mathrm{SSE}$
$204.0 \mathrm{SSW}$
$198.5 \mathrm{SSW}$
$256.5 \mathrm{WSW}$
$194.0 \mathrm{SSW}$
$92.0 \mathrm{E}$
$41.5 \mathrm{NE}$
$86.9 \mathrm{~S}$
$143.0 \mathrm{SE}$
$161.0 \mathrm{SSE}$
$150.0 \mathrm{SSE}$
$172.5 \mathrm{~S}$
$158.5 \mathrm{SSE}$
$148.0 \mathrm{SSE}$
$133.5 \mathrm{SE}$
$141.5 \mathrm{SE}$
$142.5 \mathrm{SE}$
$170.5 \mathrm{~S}$
$338.0 \mathrm{NNW}$
$326.0 \mathrm{NW}$
$19.5 \mathrm{NNE}$
$\begin{array}{lcl}\text { WIND WIND } & \text { STABE } \\ \text { SPEED DIRECTION } & \text { ILITY }\end{array}$$$
5.2
$$$$
6.0
$$$$
2.4
$$$$
3.7
$$$$
3.2
$$

3.0

3.6

2.3

2.7

3.6

4.4

6.6

6.7
5.9

6.0

7.4

6.9

5.5
4.5

2.6

2.0

3.8

4.5
2.2

\begin{tabular}{cl} 
WIND & \multicolumn{2}{l}{ WIND } \\
SPEED & DIRECTION \\
(MPH) & \\
2.6 & 169.5 SSE \\
0.8 & 122.5 ESE \\
0.4 & $346.0 \mathrm{NNW}$ \\
2.6 & $185.0 \mathrm{~S}$ \\
3.5 & $176.5 \mathrm{~S}$ \\
1.3 & $140.5 \mathrm{SE}$ \\
1.3 & $151.0 \mathrm{SSE}$ \\
1.7 & $184.0 \mathrm{~S}$ \\
1.3 & $201.5 \mathrm{SSW}$ \\
2.2 & $164.0 \mathrm{SSE}$ \\
0.7 & $218.0 \mathrm{SW}$ \\
1.7 & $124.5 \mathrm{SE}$ \\
2.0 & $52.5 \mathrm{NE}$ \\
2.4 & $130.5 \mathrm{SE}$ \\
4.4 & $176.0 \mathrm{~S}$ \\
5.6 & $150.5 \mathrm{SSE}$ \\
4.2 & $147.0 \mathrm{SSE}$ \\
3.2 & $137.5 \mathrm{SE}$ \\
3.0 & $139.0 \mathrm{SE}$ \\
1.7 & $136.5 \mathrm{SE}$ \\
1.0 & $137.0 \mathrm{SE}$ \\
0.4 & $283.5 \mathrm{WNW}$ \\
1.3 & $234.0 \mathrm{SW}$ \\
0.7 & $306.5 \mathrm{NW}$ \\
&
\end{tabular}

STAB- TEMP

ITY LAPSE

(C)

-0.2
-0.3

$-0.2$

0.0

0.0

0.0
-0.2

$-0.3$

$-0.2$

$-0.3$

$-0.2$

$-0.3$

$-0.5$

$-0.9$

$-0.9$

$-1.7$

$-1.4$

$-1.1$

$-1.1$

$-0.6$

$-0.3$

0.0

0.0

$-0.2$

$-0.2$

DATA FROM THE TEN METER TOWER

DAILY SUMMARY

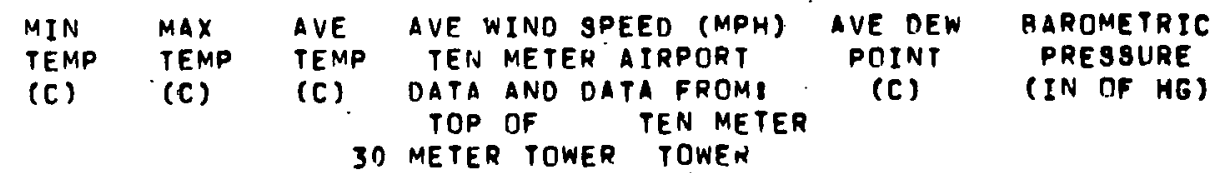

ST. ANTHONY

$$
\text { MINE. }
$$

$16.5 \quad 21.1 \quad 18.5 \quad 0.3$

3.5

3.0

ALAIJOIJERQUE

A IRPOR T

12.8

$23.3 \quad 18.3 \quad 6.9$

6.8

10.0

29.87 
Table A.13. Meteorologica1 Data from 18 September 1979

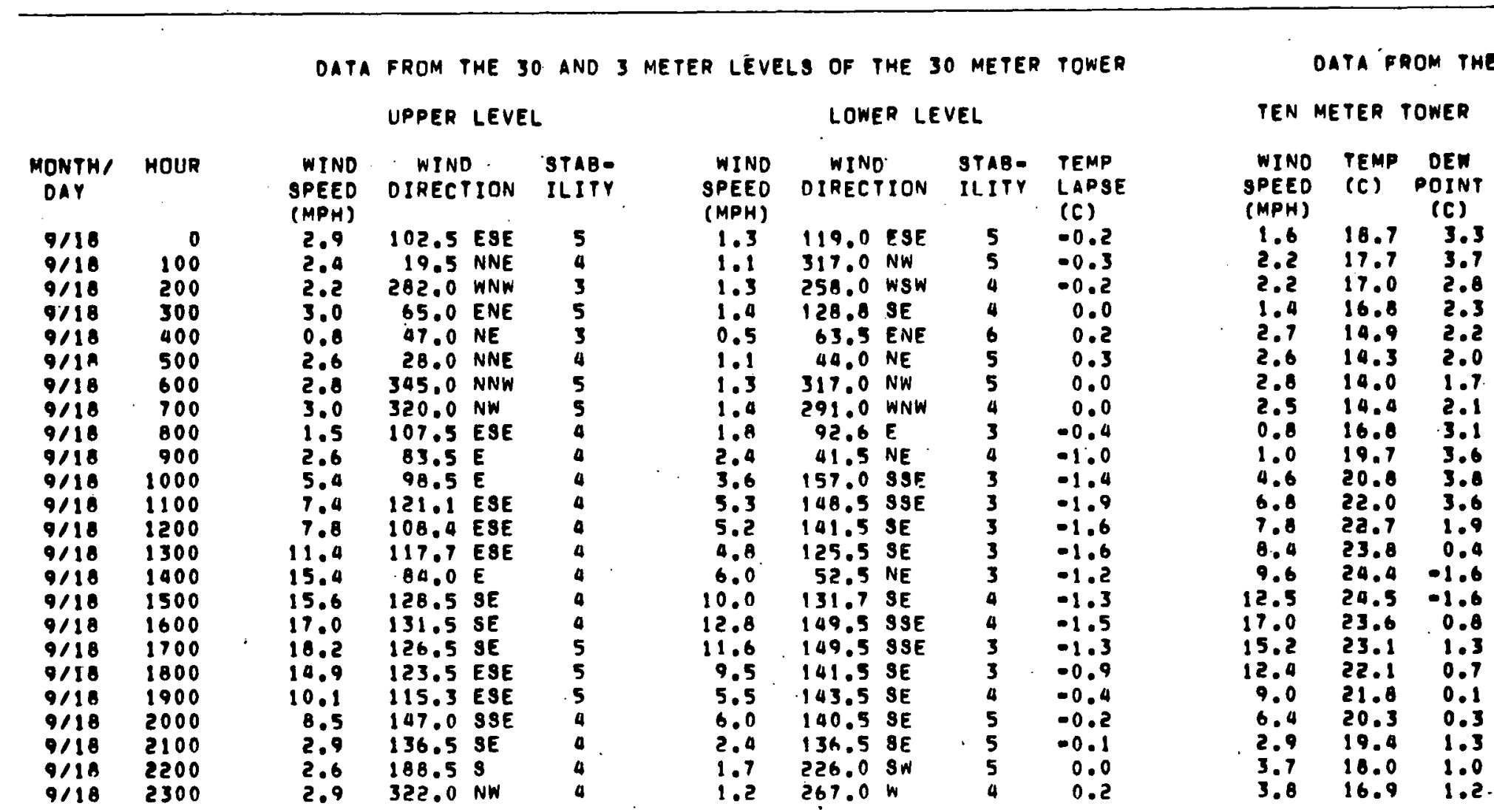

DAILY SUMMARY

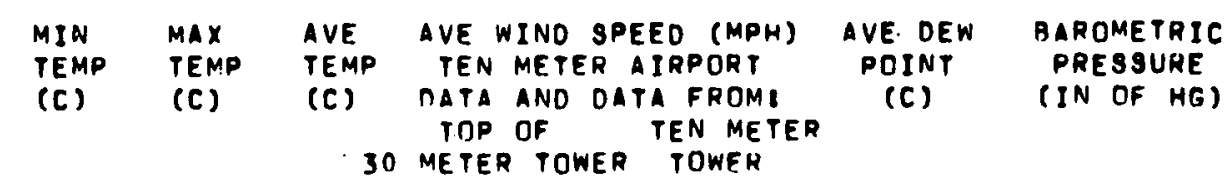

ST. ANTHONY

$\begin{array}{lccccccc}\text { MINE } & 14.0 & 20.5 & 19.5 & 6.8 & 5.8 & 1.7 & \\ \begin{array}{l}\text { ALBUQUERQUE } \\ \text { AIRPORT }\end{array} & 12.2 & 24.4 & 18.3 & 6.9 & 1.9 & 8.3 & 24.92\end{array}$


Table A.14. Metéorological Data from 19 September 1979

DATA FROM THE 30 and 3. METER LEVELS OF THE 30 METER TOWER UPPER LEVEL

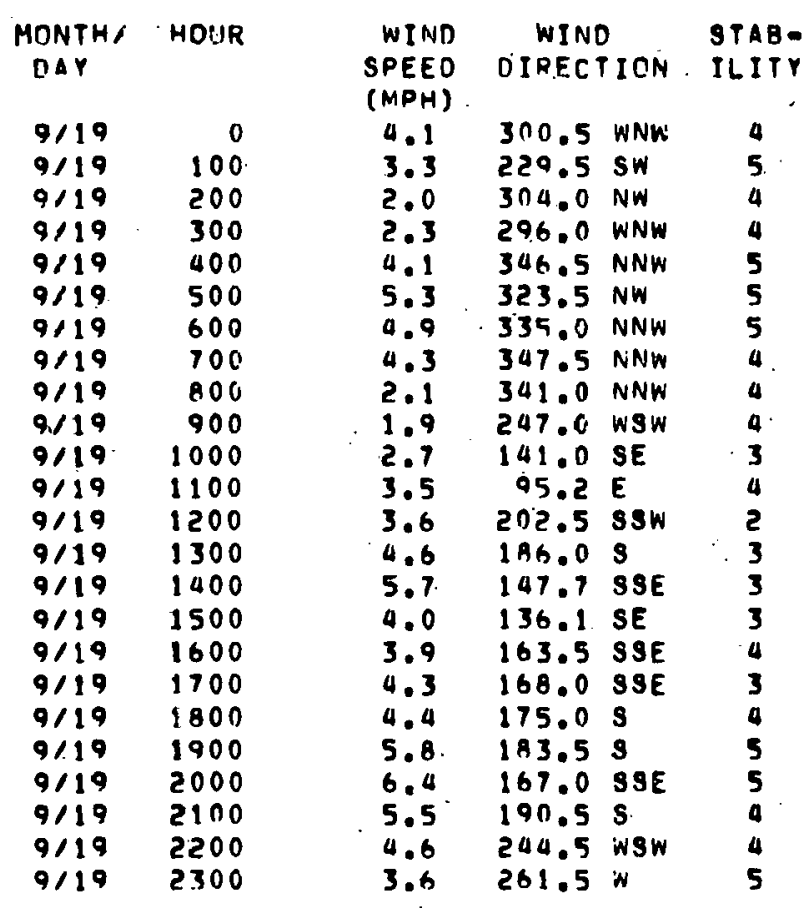

LOWER LEVEL

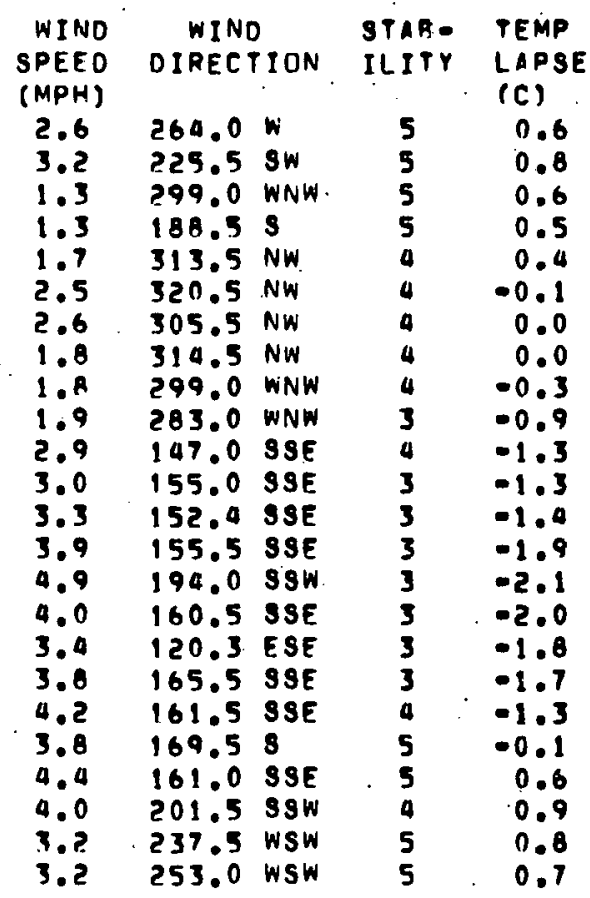

DATA FROM PHE

\section{TEN METER TOWER}

$\begin{array}{lll}\text { WINO } & \text { TEMP } & \text { OEW } \\ \text { SPEEO } & \text { (C) } & \text { POINT } \\ \text { (MPH) } & & \text { (C) } \\ 3.9 & 17.1 & 1.0 \\ 2.3 & 16.1 & 1.4 \\ 4.9 & 19.3 & 1.1 \\ 3.2 & 14.3 & 0.8 \\ 3.3 & 13.0 & 0.3 \\ 2.8 & 12.8 & 0.2 \\ 1.7 & 13.3 & 0.2 \\ 3.1 & 13.6 & 0.2 \\ 1.8 & 15.4 & 1.3 \\ 1.5 & 18.1 & 1.7 \\ 2.7 & 19.5 & 1.4 \\ 3.2 & 20.5 & 1.4 \\ 3.4 & 21.0 & 1.9 \\ 3.8 & 22.3 & 1.2 \\ 9.9 & 23.2 & 0.6 \\ 4.3 & 24.3 & 0.7 \\ 9.4 & 24.9 & 0.8 \\ 5.0 & 25.9 & 1.0 \\ 3.4 & 25.5 & 0.1 \\ 3.8 & 25.0 & 0.2 \\ 1.8 & 23.9 & -0.1 \\ 3.1 & 20.7 & 0.7 \\ 3.2 & 19.7 & 1.3 \\ 3.2 & 17.5 & 0.8\end{array}$

OAILY SUMMARY

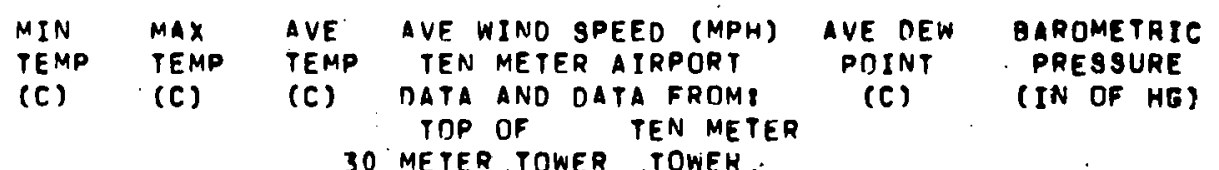

\begin{tabular}{|c|c|c|c|c|c|c|c|}
\hline MINE & 12.8 & 25.5 & 19.2 & 4.0 & 3.3 & 0.8 & \\
\hline $\begin{array}{l}\text { AL BUAUERQUE } \\
\text { AIRPORT }\end{array}$ & $12 . A$ & 26.7 & $20.0^{\circ}$ & 8.2 & B. 2 & 1.2 & 29.60 \\
\hline
\end{tabular}


THIS PAGE

\section{WAS INTENTIONALLY LEFT BLANK}




\section{APPENDIX B. ESTIMATES OF RADON RELEASE RATES FROM RIPPING, REMOVAL, AND CRUSHING OF ORE}

The radon release rates from static sources such as exposed ore, overburden, and marginal ore storage piles can be measured; but rates from dynamic operations such as ripping, removal, and crushing of ore are difficult to measure. To obtain values for the release rates from these processes, it is necessary to estimate the radon concentration in the soil pore space. Radion accumulated within these spaces is released when ore is ripped or crushed. This release may be estimated given an ore production rate of 2000 tons/day and an ore quality of $0.07 \% \mathrm{U}_{3} 0_{8}(196 \mathrm{pCi} / \mathrm{g})$, assuming that the ore is in secular equilibrium with $\mathrm{Ra}-226$. The radon activity entering the pore space will be equal to the radium activity in the ore multiplied by the emanation factor $(E)$. Austin (1975) determined an emanation factor of $7 \%$ for Laguna ore (near the St. Anthony Mine). The annual radon activity released $\left(Q_{0}\right)$ from the daily production of 2000 tons (approximately 1800 metric tons) is:

$$
\begin{aligned}
Q_{0}= & (0.07) \times(285 \text { working days } / \text { year }) \times(1800 \text { metric tons } \\
& \left.\times 10^{6} \mathrm{~g} / \text { metric ton }\right) \times(196 \mathrm{pCi} / \mathrm{g}) \times\left(10^{-12} \mathrm{C} 1 / \mathrm{pCi}\right) \\
= & 7.04 \mathrm{Ci} / \mathrm{yr}
\end{aligned}
$$

Assuming that the flux weasurements are proportional to the radium content, the annual radon releases from the disturbance of inclusive waste $\left(Q_{i}\right)$ and overburden $\left(Q_{b}\right)$ are, respectively:

$$
\begin{aligned}
& Q_{i}=7.04 \mathrm{Ci} / \mathrm{yr} \times\left(\frac{1.69 \mathrm{pCi} / \mathrm{m}^{2} \cdot \mathrm{s}}{14.18 \mathrm{pCi} / \mathrm{m}^{2} \cdot \mathrm{s}}\right) \times\left(\frac{0.75 \text { waste fraction }}{0.25 \text { ore fraction }}\right) \\
& Q_{i}=2.52 \mathrm{Ci} / \mathrm{yr}
\end{aligned}
$$

where 1.69 and $14.18 \mathrm{pCi} / \mathrm{m}^{2} \cdot \mathrm{s}$ are the average flux values from inclusive waste and ore, respectively (Table 18); and 0.75 and 0.25 are the fractions of waste and ore in the ore zone (Table 18).

$$
\begin{aligned}
& \mathrm{Q}_{\mathrm{b}}=7.04 \mathrm{Ci} / \mathrm{yr} \times\left(\frac{0.08 \mathrm{pC} / \mathrm{m}^{2} \cdot \mathrm{s}}{14.18 \mathrm{pCi} / \mathrm{m}^{2} \cdot \mathrm{s}}\right) \times\left(\frac{12 \text { overburden }}{\text { ore }}\right) \\
& \mathrm{Q}_{\mathrm{b}}=0.48 \mathrm{Ci} / \mathrm{yr}
\end{aligned}
$$

where 12 is the overburden to ore ratio, based on the dimensions of the inactive pit (Table 15); and 0.08 is the average flux estimated for the overburden from Levels 1 to 3 (Table 16).

$Q_{Y}$, the annual release from dynamic mining procedures, is thus:

$$
Q_{r}=Q_{o}+Q_{i}+Q_{b}=10.04 \mathrm{Ci} / \mathrm{yr}
$$




\section{Dis.tribution of NUREG/CR-1583 (ANL/ES-97)}

\section{Interna1:}

J.E. Carson (2)

M.M. Momeni (2)

C.E. Dungey

A.E. Packard

A.J. Dvorak

D.R. Rayno (2)

D. Grahn

C.J. Roberts

P.F. Gustafson

C. Sabau (2)

W.J. Hallett

W.E. Kisieleski

J.H. Kittel

N.D. Kretz (2)

J.B. Lindstrom (2)

W.E. Massey.

R.E. Rowland

W.K. Sinclair

D.J. Wyman

ANL Contract File

ANL Libraries (2)

TIS Files (6)

\section{Externa1:}

USNRC, for distribution per RU (455)

DOE-TIC (2)

Manager, Chicago Operations and Regional office, DOE

Chief, Office of Patent Counsel, DOE-CORO

President, Argonne Universities Association

Abbiss, J., United Nuclear - Homestake Partners, P.0. Box 3951, Albuquerque, NM 87110

Beverly, R.G., Union: Carbide Corp., P.0. Box 1029, Grand Junction, C0 81501

Breslin, A.J., Environmental Measurements Lab., USDOE, New York, NY $10014^{\circ}$

Campbel1, R.H., Department of Energy, Albuquerque Operations Office, P.O. Box 5400 , Albuquerque, NM 87115

Geiger, E., Eberline Co.,. Santa. Fe, NM 87501

McKiernan, J.W., Sandia Laboratories, Albuquerque, NM 87115

Phillips, C.R., Univ. of Toronto, Dept. of Chemical Engineering, Toronto, Ontario, Canada M5S $1 \mathrm{~A} 4$

Thompson, W.E., Div. Fuel Cycle and Material Safety, USNRC., Washington (100). 